\title{
CARACTERIZAÇÃO DOS FATORES RELACIONADOS AO SUCESSO DE UM EMPREENDEDOR RURAL
}

\author{
DALTRO CELLA
}

Dissertação apresentada à Escola Superior de Agricultura "Luiz de Queiroz", Universidade de São Paulo, para obtenção do título de Mestre em Ciências, Área de Concentração: Economia Aplicada.

\author{
P I R A C I C A B A \\ Estado de São Paulo - Brasil \\ Fevereiro - 2002
}




\title{
CARACTERIZAÇÃO DOS FATORES RELACIONADOS AO SUCESSO DE UM EMPREENDEDOR RURAL
}

\author{
DALTRO CELLA \\ Engenheiro Agrônomo e Administrador de Empresas
}

Orientador: Prof. Dr. FERNANDO CURI PERES

\begin{abstract}
Dissertação apresentada à Escola Superior de Agricultura "Luiz de Queiroz", Universidade de São Paulo, para obtenção do título de Mestre em Ciências, Área de Concentração: Economia Aplicada.
\end{abstract}

\author{
PIR A C I C A B A \\ Estado de São Paulo - Brasil \\ Fevereiro - 2002
}


Dados Internacionais de Catalogação na Publicação (CIP)

DIVISÃO DE BIBLIOTECA E DOCUMENTAÇÃO - ESALQ/USP

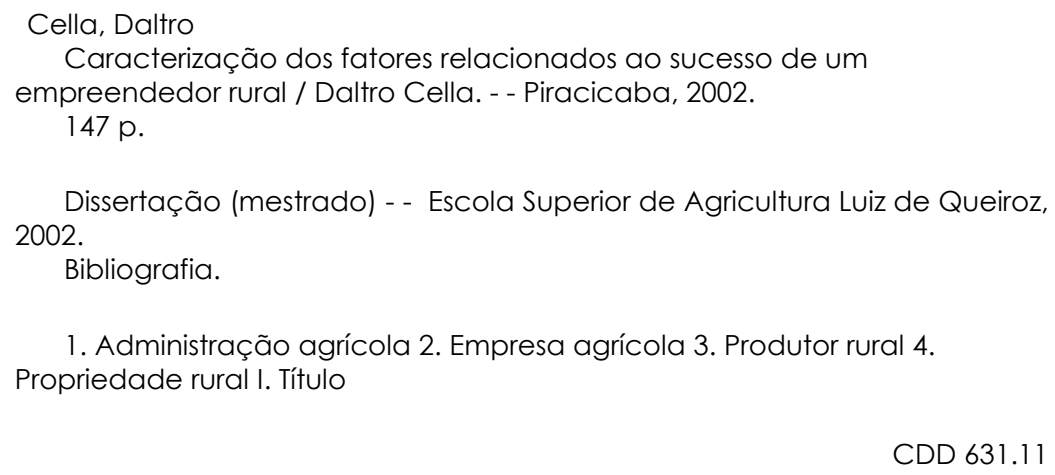

CDD 631.11

\section{"Permitida a cópia total ou parcial deste documento, desde que citada a fonte - $\mathrm{O}$ autor"}




\section{DEDICATÓRIA}

Dedico este trabalho aos meus pais, Antonio Luiz Cella e Esther Telch Cella pelo amor, carinho, honestidade e caráter;

Ao meu cunhado José Scarpari pelo exemplo de conduta de vida, pelo apoio e motivação nos momentos mais difíceis da vida;

E de forma especial à Paula Regina de Jesus Pinsetta Pavarina, esposa, amiga e companheira, minha eterna gratidão. 


\section{AGRADECIMENTOS}

Ao Prof. Fernando Curi Peres agradeço pelas orientações que me transmitiu ao longo de todo o desenvolvimento deste trabalho, pela franqueza e cordialidade. "Sei que o que (...) fez por mim certamente não é das partes mais importantes da sua biografia, mas é um exemplo do que fez por muitos outros, sempre à sua maneira discreta. Foi um amigo" (LFV).

Agradeço à equipe técnica do Departamento de Produção Vegetal da Cooperativa Tritícola Mista Alto Jacuí Ltda. (Cotrijal) pelo apoio na realização dos grupos focais e na aplicação dos questionários. Agradeço particularmente ao empenho dos senhores Jairo Marcos Kohlrausch, diretor vice-presidente, Gelson Mello de Lima, gerente da Unidade de Grãos e Flávio Marcelo Hoffmann, administrador do Departamento de Produção Vegetal para que esta pesquisa se concretizasse. Sou grato também aos produtores rurais que disponibilizaram tempo e dedicação para contribuir com este trabalho.

Ao pesquisador da Embrapa Florestas, Dr. Derli Dossa agradeço pelas idéias transmitidas, pelas sugestões e apoio ao desenvolvimento deste trabalho. Sou grato também às contribuições dos professores Evaristo Marzabal Neves, José Vicente Caixeta e Pedro Valentim Marques na fase inicial de desenvolvimento deste trabalho. Aos professores Judas Tadeu Grassi Mendes e Vânia di Addario Guimarães pelo exemplo e apoio. 
Aos amigos José Roberto Canziani e Elaine Mendonça Bernardes pela companhia agradável, pelas sugestões e principalmente pelo apoio e incentivo nos momentos críticos do desenvolvimento deste trabalho.

Aos amigos Luis Alberto, Selemara e Luisa Ferreira Garcia pelo convívio inesquecível e pelo companheirismo.

Agradeço a todos aqueles que tornaram a permanência em Piracicaba mais agradável: André Sbrissia, Aryewerton Fortes, Bruno Brum, Carlos Magno Mendes, Cleise e Emerson Hilgemberg, Edson Bignotto, Espedito Cesário Martins, Fabiana Perobelli, Fabiano Costa, Jaênes e Cândida Miranda, José Ferreira, Leopoldo Saboya, Marcelo Rezende, Ricardo Perina e Robson Mafioletti.

Agradeço aos meus irmãos Augusta, Vitório, Plínio, Naides, Janete, Enos, Olidete, Luis Antonio e Sadi, pelo incentivo e carinho a mim dispensados, que foram importantes para que eu atingisse meus objetivos. À Elice, agradeço por tudo.

Pela acolhida, pelo carinho e apoio recebido, sou grato ao sr. Oscar Pavarina, sra. Vera, Oscar Fábio e Silvia Maria.

Sou grato aos funcionários e professores do DEAS/ESALQ que possibilitaram a realização deste curso de Mestrado. 


\section{SUMÁRIO}

Página

LISTA DE FIGURAS ...................................................................... viii

LISTA DE QUADROS …................................................................ ix

LISTA DE TABELAS …..............................................................

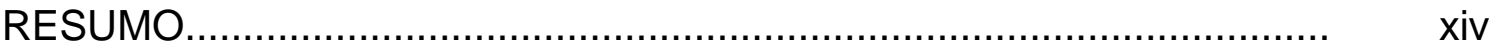

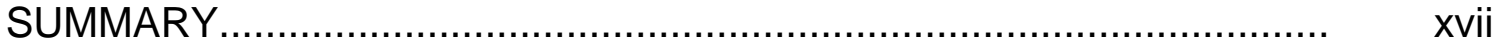

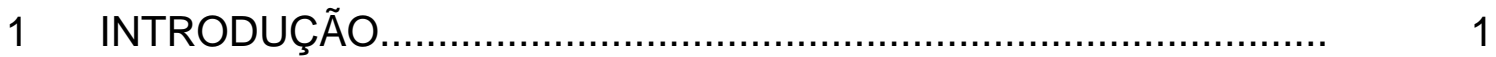

1.1 Definição do problema e justificativa ......................................... 2

2 REVISÃO DE LITERATURA ……..................................... 5

2.1 Fatores que influenciam a atividade agropecuária ....................... 5

2.2 O processo administrativo ….................................................. 14

2.2.1 O planejamento como função administrativa ............................. 14

2.2.2 A organização como função administrativa ............................... 15

2.2.3 A direção como função administrativa ..................................... 15

2.2.4 O controle como função administrativa ..................................... 16

2.3 A administração e o administrador rural ...................................... 17

2.3.1 A administração e os objetivos dos produtores rurais ................ 26

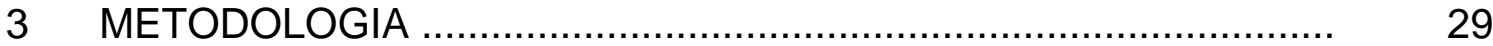

3.1 Caracterização da Cooperativa Tritícola Mista Alto Jacuí Ltda. .... 31

3.2 A técnica de "grupos focais" ................................................... 34

3.2.1 Aplicação da técnica de grupos focais junto aos produtores rurais e profissionais de assistência técnica da Cotrijal ............. $\quad 37$

3.3 Estruturação e elaboração dos questionários ............................. 38 
Página

3.3.1 Aplicação dos questionários junto aos produtores rurais e profissionais de assistência técnica da Cotrijal .......................... 46

$3.4 \quad$ Análise fatorial ........................................................................ 48

4 RESULTADOS E DISCUSSÃO …............................................ 53

4.1 Resultados obtidos com a aplicação dos grupos focais ............... 54

$4.2 \quad$ Análise dos questionários ..................................................... 62

4.2.1 Caracterização da amostra de produtores entrevistados ........... 62

4.2.2 Análise das atividades administrativas ..................................... 67

4.3 Análise dos fatores que caracterizam um bom produtor rural ....... 100

4.3.1 Considerações iniciais ......................................................... 100

4.3.2 Interpretação dos fatores .................................................... 104

$4.4 \quad$ Análise de regressão ........................................................... 116

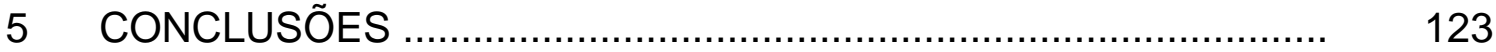

REFERÊNCIAS BIBLIOGRÁFICAS …............................................ 127

Apêndice 1: QUESTIONÁRIO .............................................................. 133

Apêndice 2: FREQUÊNCIA ABSOLUTA DE NOTAS .............................. 138

Apêndice 3: RESULTADOS DA ANÁLISE FATORIAL …….................... 140

Apêndice 4: RESULTADOS DA ANÁLISE DE REGRESSÃO ................. 144 


\section{LISTA DE FIGURAS}

Página

1 Determinantes técnicos principais de um sistema agrícola em um momento de tempo

2 Determinantes institucionais e humanos principais de um sistema agrícola em um momento de tempo

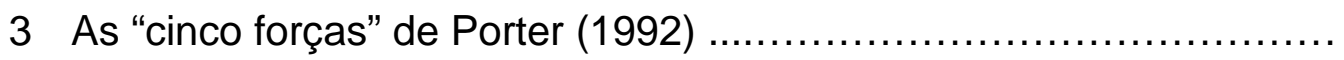

4 Gráfico de declive ..... 


\section{LISTA DE QUADROS}

Página

1 Identificação de atividades administrativas realizadas em empresas agropecuárias. Dois exemplos genéricos de atividades administrativas para cada um das diferentes funções do processo administrativo - aplicação às áreas de produção e finanças

2 Identificação de atividades administrativas realizadas em empresas agropecuárias. Dois exemplos genéricos de atividades administrativas para cada um das diferentes funções do processo administrativo - aplicação às áreas de comercialização e recursos humanos

3 Afirmativas utilizadas no questionário, agrupadas segundo atividade administrativa (produção e finanças) ................................................

4 Afirmativas utilizadas no questionário, agrupadas segundo atividade administrativa (comercialização e recursos humanos)

5 Identificação das afirmativas, e respectivas variáveis, que compõem os cinco principais fatores.

6 Identificação das afirmativas, e respectivas variáveis, que compõem os três últimos fatores 


\section{LISTA DE TABELAS}

Página

1 Idade dos produtores rurais entrevistados - comparativo com dados da ABMR

2 Escolaridade dos produtores rurais entrevistados - comparativo com dados da ABMR

3 Nota atribuída pelos entrevistados às cinco questões iniciais

4 Notas atribuídas pelos entrevistados ao planejamento estratégico e operacional da produção

5 Notas atribuídas pelos entrevistados ao planejamento estratégico e operacional das finanças

6 Notas atribuídas pelos entrevistados ao planejamento estratégico e operacional da comercialização

7 Notas atribuídas pelos entrevistados ao planejamento estratégico e operacional dos recursos humanos

8 Notas atribuídas pelos entrevistados à organização estratégica e operacional da produção

9 Notas atribuídas pelos entrevistados à organização estratégica e operacional das finanças 
Página

10 Notas atribuídas pelos entrevistados à organização estratégica e operacional da comercialização

11 Notas atribuídas pelos entrevistados à organização estratégica e operacional dos recursos humanos

12 Notas atribuídas pelos entrevistados à direção estratégica e operacional da produção

13 Notas atribuídas pelos entrevistados à direção estratégica e operacional das finanças

14 Notas atribuídas pelos entrevistados à direção estratégica e operacional da comercialização

15 Notas atribuídas pelos entrevistados à direção estratégica e operacional dos recursos humanos

16 Notas atribuídas pelos entrevistados ao controle estratégico e operacional da produção

17 Notas atribuídas pelos entrevistados ao controle estratégico e operacional das finanças

18 Notas atribuídas pelos entrevistados ao controle estratégico e operacional da comercialização

19 Notas atribuídas pelos entrevistados ao controle estratégico e operacional dos recursos humanos

20 Coeficientes da regressão linear simples - variável dependente: auto-avaliação dos entrevistados 
21 Coeficientes da regressão linear simples e teste $F$ - variável dependente: auto-avaliação dos entrevistados

22 Coeficientes da regressão linear simples - variável dependente: avaliação dos entrevistados pelos pares

23 Coeficientes da regressão linear simples e teste $F$ - variável dependente: avaliação dos entrevistados pelos pares

24 Coeficientes da regressão linear simples - variável dependente: avaliação dos entrevistados pelos técnicos

25 Coeficientes da regressão linear simples e teste $F$ - variável dependente: avaliação dos entrevistados pelos técnicos

26 Frequência absoluta de notas atribuídas pelos entrevistados à satisfação com a atividade agrícola, situação atual da agricultura, preocupação com a preservação do meio ambiente e com a qualidade da própria produção e às atividades administrativas

27 Cargas fatoriais dos 8 fatores analisados e comunalidades das 32 atividades administrativas

28 Autovalor (eigenvalue), percentual de variância e percentual de variância acumulada dos 8 fatores analisados

29 Coeficientes da regressão linear simples - variável dependente: auto-avaliação dos entrevistados

30 Coeficientes da regressão linear simples e teste $F$ - variável dependente: auto-avaliação dos entrevistados 
Página

31 Coeficientes da regressão linear simples - variável dependente: avaliação dos entrevistados pelos pares

32 Coeficientes da regressão linear simples e teste $F$ - variável dependente: avaliação dos entrevistados pelos pares

33 Coeficientes da regressão linear simples - variável dependente: avaliação dos entrevistados pelos técnicos

34 Coeficientes da regressão linear simples e teste $F$ - variável dependente: avaliação dos entrevistados pelos técnicos 


\title{
CARACTERIZAÇÃO DOS FATORES RELACIONADOS AO SUCESSO DE UM EMPREENDEDOR RURAL
}

\author{
Autor: DALTRO CELLA \\ Orientador: Prof. FERNANDO CURI PERES
}

\section{RESUMO}

A fim de identificar os fatores que descrevem um empreendedor rural bem sucedido, três grupos focais foram realizados com produtores rurais e profissionais da assistência técnica da Cooperativa Tritícola Mista Alto Jacui Ltda. - Cotrijal em Não-Me-Toque, estado do Rio Grande do Sul. Algumas variáveis foram consideradas importantes para explicar por que um produtor é considerado bem ou mal sucedido, além da habilidade em produzir lucro. Entre estas variáveis foram apontadas: (1) competência, dada pelo domínio do conhecimento sobre a tecnologia, pela habilidade de conduzir as atividades de produção e comercialização e por ter atitudes em conformidade com os valores do grupo social de cooperados; (2) constante procura por informações técnicas e econômicas; (3) participação em eventos ou cursos que ampliem sua qualificação profissional; (4) disposição e habilidade em promover parcerias, associações ou condomínios de produção; (5) habilidade em diversificar sua produção, como estratégia para diminuição de riscos; (6) disposição em adotar novas idéias, tecnologias ou sistemas de produção; (7) habilidade em organizar a produção e a propriedade rural; (8) existência de sistemas de controle 
financeiro dos gastos e receitas; (9) planejamento da produção e das atividades da empresa; (10) liberdade em fixar os próprios horários e autonomia decisória, que permite ao produtor tirar férias; (11) envolvimento direto da família com a empresa rural; (12) promoção de um bom padrão de vida para a família, inclusive oferecendo oportunidades de educação formal aos filhos; (13) envolvimento com os assuntos comunitários; e, finalmente, (14) preservação do meio ambiente e ser exemplo para outros empresários rurais. Um questionário com 37 afirmações/questões foi aplicado a uma amostra de 140 produtores rurais associados à Cotrijal. As afirmativas foram baseadas nas características sugeridas pelos grupos focais e organizadas de acordo com as quatro funções gerenciais (planejamento, organização, direção e controle), em dois níveis (estratégico e operacional) e nas quatro áreas de atuação da empresa (produção, finanças, comercialização e recursos humanos). A grande quantidade de dados foi condensada, ao se definir oito fatores (a partir da análise fatorial multivariada) que compreenderam $62,3 \%$ da variância total da amostra: (1) financeiro; (2) planejamento comercial; (3) comunicação e informação; (4) planejamento pessoal; (5) gerenciamento de pessoal; (6) organização da produção; (7) aproveitamento de oportunidades; e (8) experiência comercial. Três equações de regressão linear foram estimadas com as notas atribuídas à capacidade administrativa dos produtores rurais como variáveis dependentes. As notas foram atribuídas pelos próprios produtores, por outros produtores entrevistados (pares) e pelos profissionais da assistência técnica da Cotrijal. As equações mostram que quatro fatores são estatisticamente significativos em explicar as notas: financeiro, comunicação e informação, planejamento pessoal e aproveitamento de oportunidades. Outras três variáveis genéricas também foram estatisticamente significativas: satisfação pessoal, qualidade dos produtos e controle físico e financeiro de gastos e receitas. Embora as equações explicassem somente uma pequena parte das variações nas notas atribuídas à capacidade administrativa dos 
produtores rurais (explicação entre 14 e 27\%, medida pelo coeficiente $R^{2}$ ajustado), são significativas, conforme medidas pelo teste estatístico F. 


\title{
FACTORS THAT DESCRIBE A SUCCESSFUL RURAL ENTREPRENEUR
}

\author{
Author: DALTRO CELLA \\ Adviser: Prof. FERNANDO CURI PERES
}

\section{SUMMARY}

In order to identify the factors that describe a successful rural entrepreneur, three focus groups were conduced with farmers and extension agents of the Wheat Cooperative of Alto Jacui - Cotrijal at Não-Me-Toque, Rio Grande do Sul State. Several variables were suggested as playing important roles in explaining why a farmer is considered successful or not, besides their ability to produce profits. Among these variables are: (1) the farmer competence as shown by his technological knowledge, his ability to implement production and trading processes, and by his attitudes in conformity with the values of the Cotrijal's social group; (2) farmer's constant search for new technical and economical informations; (3) farmer attendance of courses and events that will enhance its technical qualifications; (4) farmers willingness and ability to promote partnerships, associations and group production; (5) farmers ability to diversify their activities as strategies to reduce risks; (6) farmers willingness to adopt knew ideas, technologies or production systems; (7) farmers ability to organize production and their farms; (8) the existence of a system of expenditure and receipt control; (9) how they plan production and other farm activities; (10) farmers that have freedom to travel and to set their own time to 
work; (11) farmers that have their families involved with the farm business; (12) their ability to provide for children formal education and to give their family higher levels of consumption; (13) farmers involvement with the community subjects; and finally, (14) farmers that are seen as persons that preserves the environment and as model for other farms. A questionnaire with 37 statements were applied to 140 farmers of Cotrijal. The statements were based on the focus group suggested characteristics and organized according to the four management functions (planning, organizing, direction, and control), on two strategic levels (strategic and operational) and on the four firm's working areas (finance, production, commercialization, and human resource). The huge amount of data were condensed by defining eight factors (from multivariate factor analysis) that comprised $62.3 \%$ of the sample total variance: (1) financial, (2) commercial planning, (3) communication and information, (4) personal planning, (5) human resource management, (6) production organization, (7) dealing with new opportunities, and (8) previous commercial experience. Three linear regression equations were estimated with attributed grades for farmers' entrepreneurship ability as the dependent variables. Grades were attributed by the farmers (themselves), by other interviewed farmers, and by the extension agents of Cotrijal. Equations show that four factor were statistically significant in explaining the grades: financial, communication and information, personal planning, and dealing with new opportunities. Other three general variables also were statistically significant in explaining the grades: personal satisfaction, product quality, and physical and financial control. Although the equations explained only a small part of the variations in the grade attributed to the farmers entrepreneurs ability (from 14 to $27 \%$ explanation measured by the adjusted $R^{2}$ coefficient) they showed high significant levels as measured by the $F$ statistic test. 


\section{INTRODUÇÃO}

Inúmeras são as variáveis que condicionam ou afetam o sucesso de um empreendimento rural, a despeito da região geográfica de exploração e do tipo de atividade desenvolvida. Ao mesmo tempo, vários são os condicionantes dos resultados técnicos e econômicos obtidos pelos produtores rurais, sendo difícil determinar quais são aqueles que contribuem fundamentalmente para caracterizar um bom produtor rural.

A utilização de determinada técnica de cultivo, a introdução de uma nova variedade, a combinação ótima de produtos, novas estruturas para a contratação de mão-de-obra entre outros fatores, são relacionadas ao sucesso de determinado empresário ou grupo de empresários rurais. Entretanto, a utilização indiscriminada de uma técnica produtiva ou mesmo de uma estratégia que vem obtendo sucesso com um produtor rural pode não conduzir ao resultado desejado com sua aplicação em outros estabelecimentos. Por outro lado, o desempenho insatisfatório de alguns agropecuaristas pode estar associado à falta de organização ou de visão sistêmica do processo produtivo ou do complexo agroindustrial (atividades a montante e a jusante na cadeia produtiva agropecuária). Neste contexto, uma variável que pode significar diferenciação entre os resultados econômicos obtidos por membros de um grupo de produtores rurais é a capacitação administrativa do empresário rural, que contribui positivamente para o sucesso deste. 


\subsection{Definição do problema e justificativa}

Este trabalho tem o objetivo de investigar quais os principais fatores que contribuem para a caracterização de um produtor rural de sucesso, com ênfase em sua capacidade administrativa. O problema central torna-se, assim, o diagnóstico dos condicionantes geralmente vinculados ao sucesso do empresário rural.

Muito embora a atividade agrícola esteja sujeita às regras de mercado, como qualquer outra atividade, admite-se que a empresa rural desempenhe um papel adicional de realização pessoal (ou familiar) do indivíduo (ou grupo) que a dirige. Assim, a análise do sucesso de um empreendimento rural deve extrapolar a simples noção de maximização do lucro nas atividades desenvolvidas, conjugando elementos subjetivos como a necessidade de realização dos desejos e aspirações do proprietário. Envolve, pois, elementos como o convívio familiar e social, autonomia decisória, reconhecimento comunitário, enfim, variáveis que podem interferir na ou determinar a capacidade administrativa do produtor rural.

O trabalho objetiva não somente a caracterização qualitativa de um produtor rural de sucesso, como também a determinação de fatores quantitativos que permitam descrever com mais propriedade como um empresário rural bem sucedido aplica as funções administrativas (planejamento, organização, direção e controle) nas diferentes áreas de atuação da empresa rural (produção, finanças, comercialização e recursos humanos). O conhecimento destas características e do valor dos fatores tem sido reconhecido como importante instrumento para o desenho de políticas:

"dos processos de diferenciação social dos agricultores e das características técnicas e econômicas das suas atividades nos parece, assim, indispensável para a formulação de políticas de 
desenvolvimento da agricultura. Apenas o conhecimento destes processos pode-nos indicar quais as técnicas que são as mais adequadas e quais são as condições necessárias para assegurar a sua eficiência, tanto para a melhoria da renda dos agricultores, como para o aumento da produção global" (Silva Neto et al., 1997, p.16).

O mapeamento de padrões de sucesso, do ponto de vista administrativo, pode colaborar para que sejam desenvolvidas estratégias ou sugeridas medidas que visem melhorar ou amenizar as disparidades existentes entre 0 gerenciamento de diferentes unidades de produção rural. Essas medidas podem ser implantadas ou difundidas com mais rigor e presteza pelos agentes de difusão de conhecimento, como institutos de pesquisa e difusão de tecnologia, instituições de ensino técnico e superior, meios de comunicação especializados (revistas, jornais ou outros informativos) e, principalmente, pelos profissionais que atuam no mercado como consultores ou assistência técnica aos produtores rurais.

A existência de poucos estudos realizados no Brasil, envolvendo a análise das quatro funções administrativas na agropecuária também justifica a realização desta pesquisa. A compreensão dos principais elementos que conduzem ao sucesso do empresário rural é de fundamental importância tanto para o planejamento das atividades futuras como para uma compreensão sistêmica dos resultados obtidos. Este diagnóstico permite não só a diminuição da instabilidade a que está sujeito o setor agropecuário como também a redução dos impactos de oscilações sobre o ambiente empresarial e pessoal.

Especificamente o trabalho visa: (a) conhecer as características que distinguem um bom produtor rural, segundo a visão dos próprios produtores e dos profissionais que Ihes fornecem assistência técnica; (b) identificar os fatores 
ou grupos de variáveis que sintetizam as características sugeridas; e (c) quantificar o efeito dos grupos de variáveis síntese (fatores) na explicação das diferentes notas atribuídas aos agricultores por sua performance como empresários rurais.

O presente trabalho está estruturado em cinco capítulos, incluindo esta introdução. O segundo capítulo envolve a revisão da literatura existente sobre a administração de empresas rurais; o terceiro compreende uma descrição da metodologia utilizada para coleta e análise dos dados, bem como uma sucinta caracterização da amostra de produtores rurais entrevistados, todos associados à Cooperativa Tritícola Mista Alto Jacuí Ltda. (Cotrijal). Os resultados obtidos e as discussões a respeito destes estão no capítulo quarto e o capítulo cinco apresenta as conclusões deste trabalho. 


\section{REVISÃO DE LITERATURA}

Este capítulo trata da revisão da literatura existente sobre a administração da empresa rural. Esta deve ser considerada como um fator que condiciona ou determina os resultados técnicos e econômicos da atividade agrícola. Inicialmente é descrita a atividade agropecuária do ponto de vista dos principais fatores que acabam influenciando os resultados obtidos pelos produtores rurais. Em seguida são feitas considerações a respeito do processo administrativo e no item seguinte é descrita a administração rural e os principais problemas envolvidos com o seu estudo e aplicação prática.

\subsection{Fatores que influenciam a atividade agropecuária}

Enquanto atividade econômica, a produção agropecuária está associada a um amplo contexto, onde uma infinidade de variáveis condicionam tanto os resultados tecnológicos como a rentabilidade e lucratividade. Alguns destes condicionantes são considerados de natureza técnica (aspectos físicos e biológicos) e outros de natureza institucional e humana (exógenos ou

endógenos à propriedade agrícola), conforme considerações de Norton \& Alwang (1993), resumidas nas Figuras 1 e 2.

Dentre os aspectos físicos que podem impactar a produção agropecuária pode-se citar: (a) oscilações meteorológicas - precipitações, ventos, geadas, alterações de temperatura, calor, luminosidade, etc; (b) características do solo topografia, fertilidade, profundidade, permeabilidade e grau de erodibilidade, 
etc.; (c) recursos hídricos - disponibilidade de água em quantidade necessária, qualidade aceitável, com a periodicidade pertinente. Tais características determinam a necessidade de drenagem ou irrigação para as culturas; (d) disponibilidade de infra-estrutura - máquinas, equipamentos, ferramentas, edificações e construções rurais, animais utilizados no processo produtivo, etc.; e (e) localização - distância da propriedade agropecuária com relação ao mercado facilitando o acesso a compra de insumos ou a venda dos produtos finais. Além desses fatores, as pragas e doenças no cultivo agrícola, bem como as doenças e enfermidades nos animais, são condições biológicas fora do pleno controle humano, que influenciam o sucesso da agropecuária. Outros condicionantes biológicos podem ser representados pelas diferentes espécies ou qualidades de sementes e animais.

Norton \& Alwang (1993) mencionam as condições institucionais e humanas que estão fora do controle ou do poder dos agentes produtivos. Tais características podem ser consideradas como exógenas ao processo produtivo, mas que impactam fundamentalmente o seu desenvolvimento. O sistema de comercialização (transporte e armazenamento dos produtos), as normas e crenças do ambiente institucional, as oportunidades de emprego e a remuneração de atividades fora do meio rural bem como outras oportunidades de mercado (afetando a oferta e a demanda de produtos agropecuários) podem ser consideradas neste item. Destaque deve ser dado ainda, ao importante papel das políticas públicas: oscilações nos preços mínimos, políticas de subsídios, acesso a crédito, concessão de incentivos regionais ou a determinadas culturas/atividades. Ao mesmo tempo, alterações macroeconômicas no próprio ou em outros países, podem afetar a atividade agropecuária, sem que haja qualquer possibilidade de interferência por parte do produtor rural. 


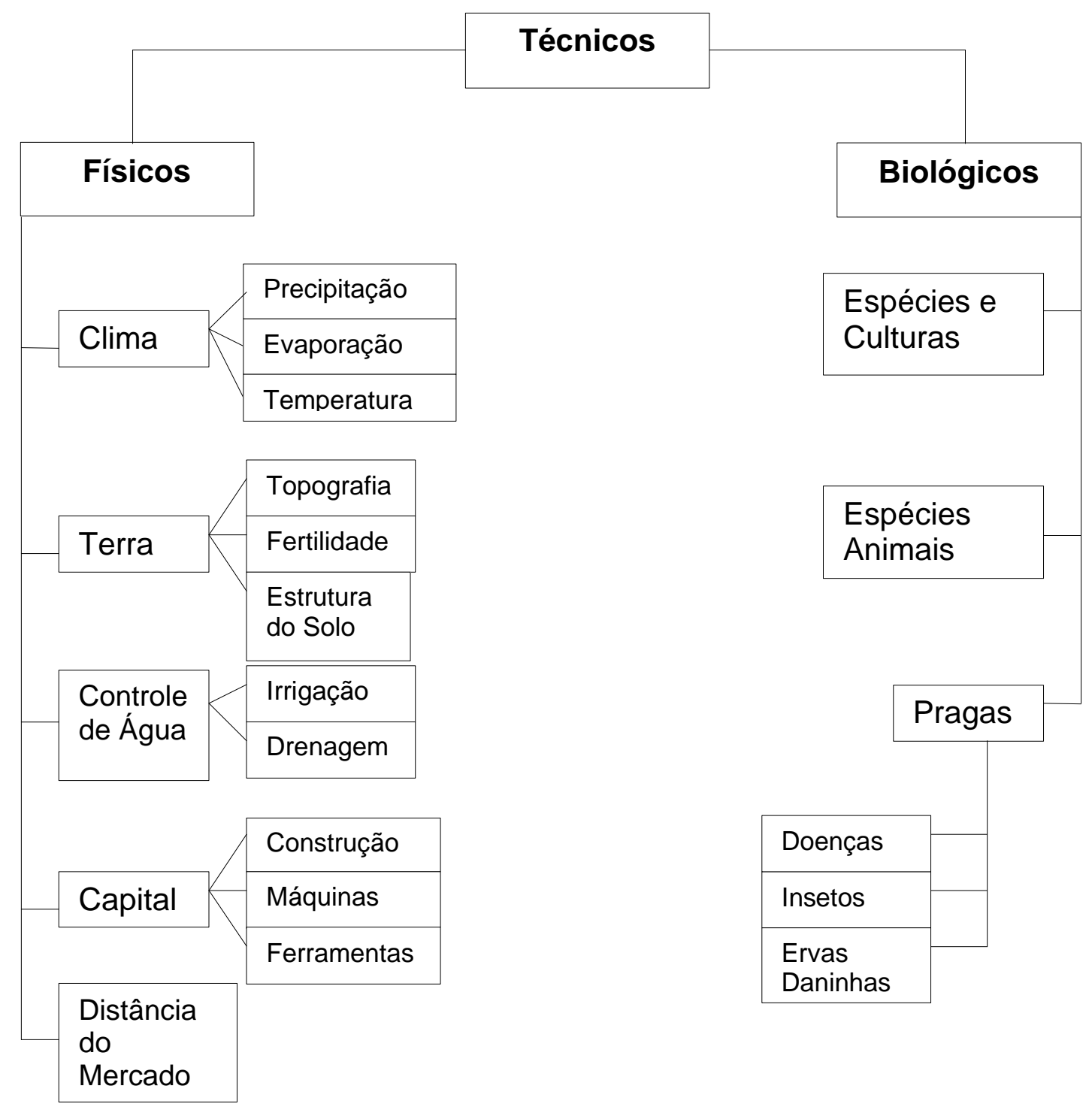

Figura 1 - Determinantes técnicos principais de um sistema agrícola em um momento do tempo.

Fonte: adaptado de Norton \& Alwang (1993, p.151). 


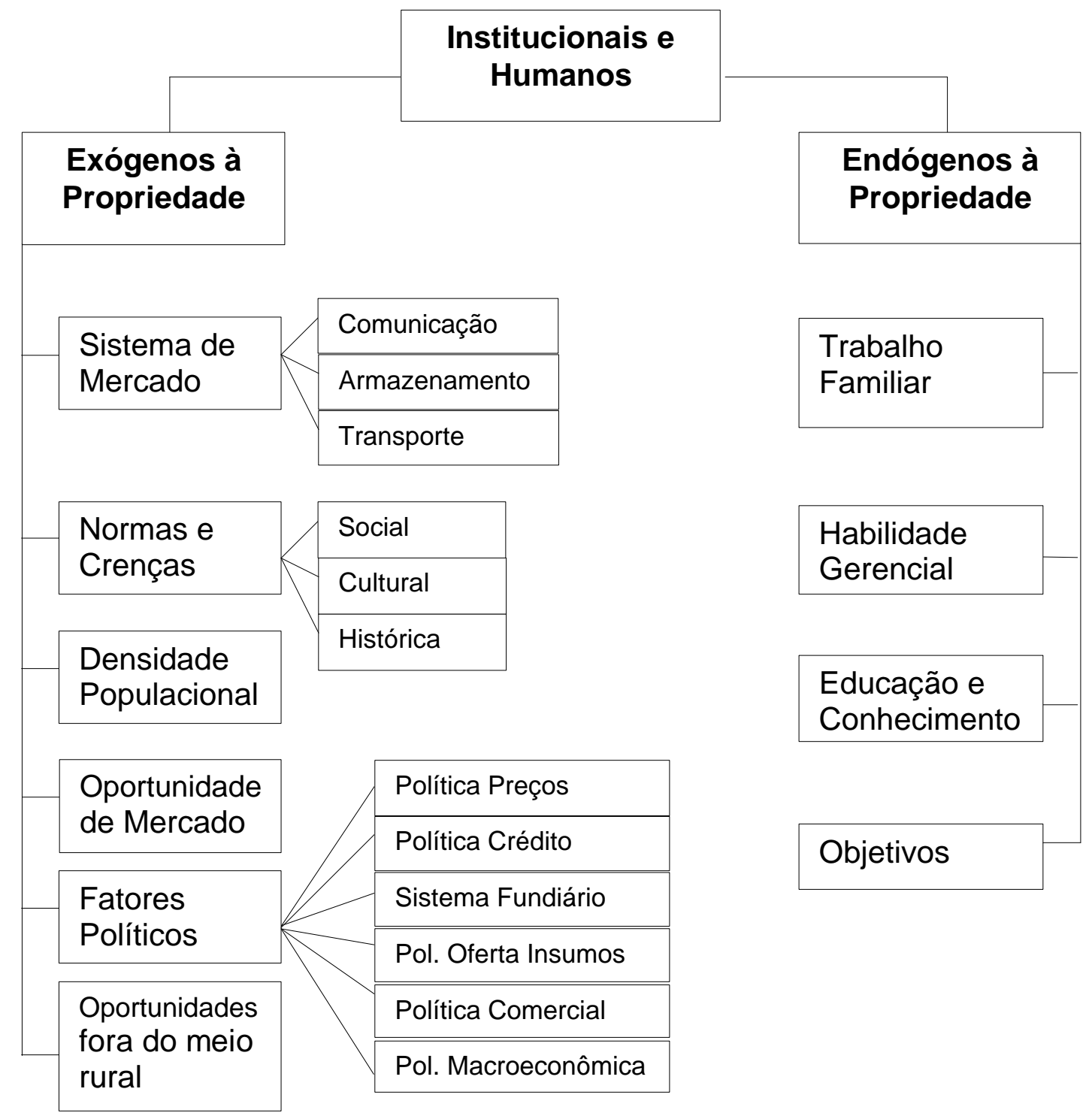

Figura 2 - Determinantes institucionais e humanos principais de um sistema agrícola em um momento do tempo.

Fonte: adaptado de Norton \& Alwang (1993, p.151). 
As características endógenas à propriedade agropecuária são também listadas por Norton \& Alwang (1993): trabalho familiar, habilidade administrativa, educação, conhecimento e determinação de objetivos. Além destas, outras características também são citadas por Salles (1981) como intrínsecas à atividade agropecuária. Entre elas, pode-se mencionar o caráter estacional, que condiciona tanto os aspectos técnicos como econômicos. Destaca a demanda de insumos produtivos e outros fatores concentrados em determinado período do ano, tais como a sazonalidade da demanda por crédito, problemas de comercialização (armazenagem, conservação, transporte e oscilações de preço), perecibilidade de alguns produtos (que deprime a renda do produtor, através da diminuição do seu poder de barganha frente aos compradores) e a irreversibilidade do processo produtivo.

Todos os mencionados fatores impactam não somente o tipo de cultura ou criação a ser desenvolvido pelo produtor, como também a produtividade por ele alcançada e a sua rentabilidade/lucratividade. Muito embora a listagem não seja exaustiva, todos os determinantes podem ser considerados, de certa forma, um reflexo estático do ambiente em que está inserido o produtor agropecuário. Torna-se importante considerar não somente o ambiente atual, como os potenciais distúrbios no status quo produtivo, motivados por eventos ou concorrência potencial. Neste sentido, é necessário considerar não somente a concorrência existente em determinado momento do tempo, como também a pressão feita por outros agentes econômicos, que acabam refletindo-se internamente à empresa. Assim, a interação e as conseqüências de cinco "forças" de concorrência descritas por Porter (1992) e sintetizadas na Figura 3, devem ser introduzidas na análise da produção agropecuária. São elas: (a) rivalidade entre os concorrentes já estabelecidos na própria indústria; (b) poder 
de negociação dos fornecedores de insumos ${ }^{1}$; (c) poder de barganha dos compradores; (d) ameaça de entrada de novos produtores no setor; refere-se à existência de barreiras ou fatores impeditivos à entrada de novos concorrentes na mesma indústria, alterando a incerteza do ambiente em que as firmas estão inseridas $^{2}$; e (e) existência de produtos substitutos fabricados em outras indústrias.

Analisando especificamente o caso da agricultura, Meira (1996), valendose do instrumental proposto por Porter (1992), considera o ambiente agropecuário como "adverso ao produtor rural". O autor considera a existência de uma "conspiração das cinco forças competitivas": número elevado de produtores agropecuários convivendo ao lado de fornecedores de máquinas, equipamentos e insumos agrícolas com alto poder de negociação e compradores de produtos agropecuários (atacadistas, cadeias de supermercados, agroindústrias e comerciantes locais oligopsonistas). Além destas desvantagens, o produtor rural depara-se com a ameaça constante de entrada de novos produtores, dadas as baixas barreiras à entrada e os elevados custos de saída da atividade agropecuária, fator este que leva os produtores a permanecerem neste setor mesmo sem a obtenção de retornos satisfatórios. Destaca também a concorrência com produtos industriais sintéticos.

${ }^{1} \mathrm{O}$ que observa-se é uma tendência de maior dependência dos produtores rurais para com seus fornecedores. Estes, além da venda de insumos, também fornecem crédito ou empréstimos, comprometendo o produtor rural com a entrega futura de parcela da produção para quitar os compromissos.

2 A existência de barreiras depende, fundamentalmente, da existência de várias forças que podem inviabilizar a entrada de novos concorrentes na indústria. Como exemplo, podem ser citadas as economias de escala ou outras desvantagens independentes da escala (existência de patentes, localização privilegiada, curva de aprendizado ou experiência), possibilidade de diferenciação do produto, necessidade de investimentos em capital físico ou financeiro, custos de mudança de uma atividade para outra (barreira à saída de determinada atividade), acesso aos canais de distribuição ou mesmo políticas governamentais que controlam o número de firmas através da concessão de licenças ou acesso à fontes de matéria prima. 
O trabalho de Santos $(1982)^{3}$, citado por Meira (1996), resume a situação da agropecuária: de um lado produtores isolados, atuando em situação de concorrência perfeita, de outro a força dos vendedores de insumos (organizados em oligopólio) e de compradores de produtos (oligopsonistas). Esta situação teria como conseqüência a "pauperização" do meio rural, onde os recursos financeiros seriam constantemente drenados ou transferidos para o meio urbano ou outras atividades econômicas. Lauschner (1993, p.262) também concorda com estas argumentações, destacando o agravante de que ocorre "articulação dos serviços de crédito, pesquisa, assistência técnica e de política governamental em função dos interesses da agroindústria e do setor de insumos rurais e não dos produtores".

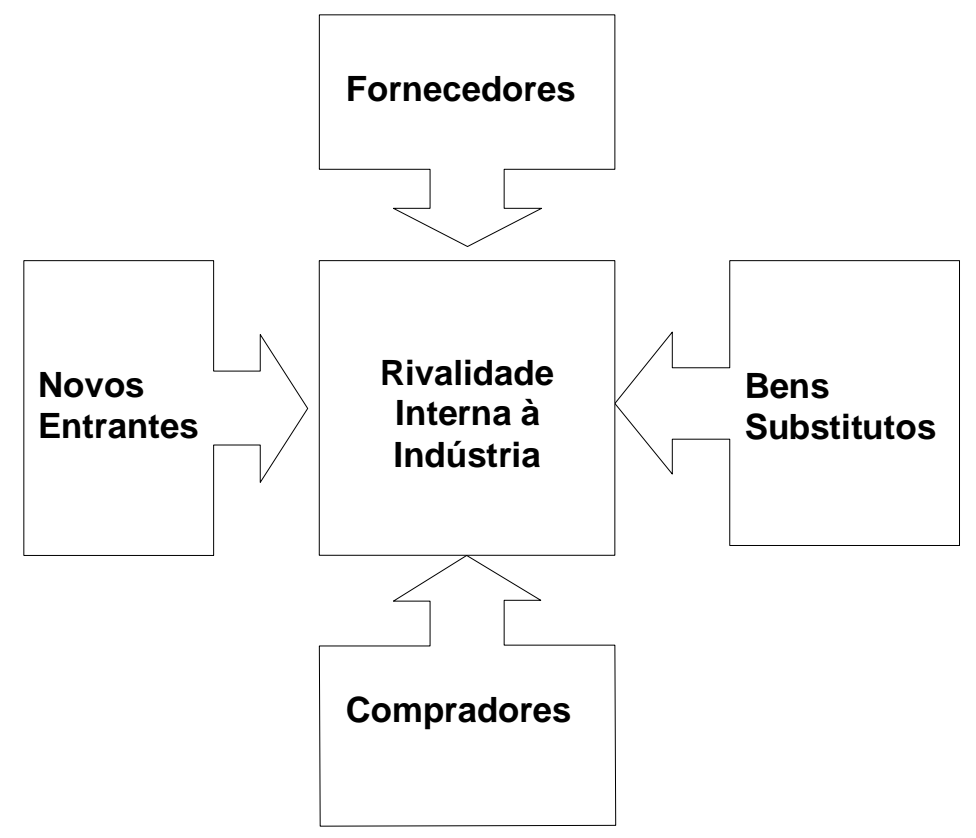

Figura 3 - As "cinco forças" de Porter (1992).

Fonte: elaboração própria, a partir de Porter (1992, p.5).

\footnotetext{
${ }^{3}$ SANTOS, A.M. dos. Administração da empresa rural e sua produtividade. Lavras, 1982. 76p.
} Dissertação (Mestrado) - Universidade Federal de Lavras, Escola Superior de Agricultura. 
Analisando especificamente os produtores rurais do Rio Grande do Sul, Brumer (1999) conclui que o processo de globalização agrava ainda mais este cenário, promovendo a compressão da lucratividade de todos os agricultores, tanto daqueles que destinam seus produtos para o mercado externo como dos que o destinam ao mercado interno. O processo de competição comercial afetaria, sob seu ponto de vista, tanto os grandes como os pequenos produtores. Sugere, pois, a adoção de novas estratégias produtivas específicas, de acordo com o tamanho da propriedade, visando aumentar a competitividade. Desta forma, o autor apresenta uma série de alternativas para minimizar os efeitos desvantajosos do aumento de competição no meio rural: profissionalização da atividade agropecuária; integração à agroindústria processadora, como alternativa para compartilhamento de risco; deslocamento da mão-de-obra familiar excedente para outros setores econômicos e a adoção de novas estratégias produtivas ou mudanças nos sistemas de produção (irrigação, estufas, higiene, apresentação dos produtos, métodos naturais ou biogenéticos de produção e controle ambiental) e implantação de formas associativas de produção (como os condomínios rurais).

Neubern et al. (1999) citam outras propostas de igual eficiência na administração de empresas agropecuárias tais como a utilização de parcerias, como estratégia para diminuição dos riscos; diversificação das atividades rurais (incluindo também atividades urbanas); melhoria no "capital humano" da empresa agropecuária, tanto do quadro funcional como também da administração, através da educação formal e informal e do treinamento; e utilização de alternativas para a comercialização dos produtos - por exemplo através de cooperativas.

O cooperativismo agropecuário ou a adesão à uma associação tem sido utilizado como uma alternativa estratégica por parte dos produtores, como uma das formas de resistência contra o processo de deslocamento da renda deste 
setor para os demais. Unindo-se forças, pode-se competir de forma menos desigual contra os setores oligopolizados ou oligopsônicos. Conforme trabalho de Bialoskorski Neto \& Balieiro (2000) ${ }^{4}$, a adesão às cooperativas aumenta o valor médio da produção animal e vegetal dos proprietários de terras entre 10 e 10.000 hectares. O aumento percentual chega a mais de $50 \%$ nos extratos até 1.000 hectares. ${ }^{5}$ Também Accarini (1987, p.38) descreve os benefícios da associação ou cooperação entre os produtores rurais, mencionando que as atividades de "armazenagem, classificação, conservação, exportação, transporte e industrialização, geralmente tornam a comercialização mais regular, organizada e eficiente, propiciando melhores lucros aos produtores atendidos". Conclui-se, pois que os resultados técnicos e econômicos obtidos pelos produtores rurais podem sofrer a influencia de uma infinidade de variáveis, algumas inclusive fora do seu poder de decisão ou atuação.

Em resumo, os produtores rurais, assim como acontece com os empresários de outras atividades econômicas, devem atentar-se ao complexo ambiente em que estão inseridos, tendo visão sistêmica (holística) da atividade desenvolvida. Devem procurar montar estratégias para defender-se frente às ameaças e saber aproveitar as oportunidades vindouras. Além deste diagnóstico, deve ser de conhecimento do produtor rural os pontos fracos e fortes das atividades por ele desempenhadas ou de sua estrutura produtiva. A capacidade administrativa do empresário rural pode ser considerada uma das determinantes dos resultados técnicos e econômicos obtidos por ele. A seqüência de decisões e atitudes para a condução das atividades agrícolas, tanto em termos produtivos como financeiros, comerciais e ligados aos recursos humanos, devem, portanto, impactar o desempenho da empresa rural.

\footnotetext{
${ }^{4}$ Para produtores agrícolas do Estado de São Paulo (dados de 1995-96).
} 


\subsection{O processo administrativo ${ }^{6}$}

A administração tem uma definição ampla, sendo constituída pela interdependência e pela interação de quatro funções distintas, que compõem o processo administrativo: planejamento, organização, direção e controle. Ressalte-se que esse processo apresenta mudanças contínuas no tempo, ou seja, não é estático e nem uma seqüência fixa de eventos. Além disso a análise do processo administrativo não deve ser considerada de maneira compartimentada; as quatro funções agem umas sobre as outras nos diferentes níveis (estratégico e operacional), onde o todo é maior que a soma das partes isoladas.

\subsubsection{O planejamento como função administrativa}

O planejamento é considerado como a função administrativa que determina antecipadamente quais são os objetivos que devem ser alcançados e como proceder para atingi-los da melhor maneira possível. O planejamento define onde se pretende chegar, o que deve ser feito, quando e em que seqüência as ações devem ser desenvolvidas. No decorrer das atividades é possível identificar as oportunidades que podem aparecer e os problemas que poderão surgir, impossibilitando atingir os objetivos traçados.

O planejamento constitui-se de um roteiro e de um determinado método que busca antecipar as conseqüências de uma ação. Pode ser entendido

\footnotetext{
${ }^{5}$ Aumento no valor médio da produção animal e vegetal de $47,5 \%$ no extrato de propriedades com menos de 10 ha., $48,5 \%$ para propriedades entre 10 e 100 ha. e $62 \%$ para propriedades entre 100 e 1.000 ha.

${ }^{6}$ Descrições apropriadas e detalhadas sobre as funções administrativas podem ser consultadas em Andrade (1996), Canziani (2001), Chiavenato (1997), Guerra (1992), Maximiano (1995) e Maximiano (1997). Estes autores serviram de base para as considerações realizadas neste capítulo.
} 
também, como um conjunto ordenado de ações ou planos com o objetivo de atingir a maximização de resultados e/ou a minimização das deficiências (Canziani, 2001).

\subsubsection{A organização como função administrativa}

A organização é a determinação das atividades necessárias para o alcance dos objetivos planejados. Etapa subseqüente ao planejamento, é responsável pelo agrupamento adequado e lógico das atividades com a finalidade de evitar conflitos entre estas dentro do sistema organizacional. É, portanto, a função administrativa que serve para agrupar e estruturar todos os recursos humanos ou não humanos de modo a atingir os objetivos predeterminados.

A organização pode ser vista como um empreendimento humano moldado intencionalmente para atingir determinados objetivos. A organização formal é aquela baseada em uma divisão de trabalho que especializa pessoas e órgãos em determinadas atividades (organização planejada). A informal é aquela que surge espontaneamente entre as pessoas, independentemente das atribuições formais. Fazem parte da organização: (a) tarefas - divisão do trabalho e conseqüente especialização das atividades e funções; (b) alocação de recursos humanos para a ocupação de cargos ou funções, em acordo com habilidades, aptidões, interesses, experiências, práticas e comportamentos individuais; (c) agrupamento de pessoas com objetivos similares; e (d) interação entre as pessoas de diferentes níveis e atividades.

\subsubsection{A direção como função administrativa}

A direção constitui a terceira função administrativa e tem o objetivo de acionar e dinamizar a organização através da atuação sobre os recursos 
humanos da empresa para que os seus objetivos sejam alcançados. Refere-se às relações interpessoais dos administradores com seus subordinados e viceversa. É uma função administrativa complexa, envolvendo orientação, assistência à execução, comunicação, liderança e motivação de todos os envolvidos, para que sejam atingidos os objetivos da organização. Portanto, dirigir significa interpretar os planos para os outros, motivar e dar as instruções sobre como executá-los. A direção ocorre em diferentes níveis: a direção global ou estratégica é a responsável pela condução e orientação empresarial, através da dinamização das atividades realizadas na empresa como um todo. Por outro lado, existe também a direção operacional, que trata da condução de pessoas, que por meio de tarefas e operações, atingem os objetivos esperados.

\subsubsection{O controle como função administrativa}

O controle é a função administrativa que acompanha e avalia o desempenho das atividades realizadas, comparando o que foi estabelecido no planejamento, na organização e na direção, com os resultados efetivos. Tem por finalidade assegurar que as metas e os objetivos planejados, organizados e divididos ajustem-se tanto quanto possível aos previamente estabelecidos. Sua função é verificar se as ações estão sendo realizadas de forma correta para que os objetivos estabelecidos sejam alcançados. Deve ser realizado continuamente, através do estabelecimento de padrões e medidas de desempenho, de modo a possibilitar a comparação com os resultados efetivos, o diagnóstico das causas que interferiram nos desvios e o desenvolvimento de ações ou estratégias corretivas.

O controle pode ser subdividido em quatro etapas: (a) estabelecimento de padrões - determinação de quais deveriam ser os resultados, ou o que esperar de uma determinada ação; (b) observação do desempenho - obtenção de informações a respeito daquilo que está sendo controlado, através das 
medidas das atividades que estão sendo desenvolvidas; (c) comparação do desempenho atual com o esperado - o controle separa o que é normal do que é excepcional para que a correção se concentre nas exceções; e (d) ação corretiva - ajuste das operações aos padrões predeterminados.

\subsection{A administração e o administrador rural}

Pode-se dizer que a administração é uma técnica que as organizações utilizam para alcançar objetivos e produzir resultados; neste sentido, a administração rural pode ser considerada parte integrante desta técnica. Uma definição sucinta de administração rural compreende todo o conjunto de decisões realizadas em um empreendimento agrícola, com o objetivo de alocar os recursos físicos, financeiros e humanos da melhor forma possível, dentre as alternativas produtivas existentes, de modo a organizar e operacionalizar a obtenção de alguns objetivos econômicos, pessoais e sociais.

A partir do momento em que o agricultor está decidindo o que vai cultivar, qual área a ser utilizada, quais e quanto de insumos serão usados ou se deve ou não adquirir mais equipamentos, ele está exercendo o papel de administrador rural. Geralmente o proprietário é o único responsável por todas as áreas da administração (produtiva, financeira, comercial e de recursos humanos).

O planejamento é a função que proporciona ao produtor rural um conhecimento maior da sua atividade, que contribui para a redução de riscos, proporcionando o crescimento das atividades de forma segura. Muitas vezes o planejamento não é explicitado de forma escrita, mas está "na cabeça" do produtor rural. Alguns agricultores apresentam certa resistência em fazê-lo formalmente em virtude da falta de conhecimento para tanto e da dificuldade em analisar as informações e os resultados. Sentem-se inseguros e/ou 
desconfiados em expor suas idéias a empregados ou a consultores por temerem a abertura das informações. Chegam a casos extremos de afastaremse dos demais produtores rurais, buscando evitar a troca de informações e com isso, restringindo o acesso a conhecimentos a respeito do negócio agropecuário.

Na condução de sua propriedade, muitas vezes o produtor rural mistura as áreas de produção, finanças, comercialização e recursos humanos. Geralmente também não têm noção clara de seus lucros efetivos, uma vez que simplesmente deduzem o que pagam daquilo que recebem. Assim, é desnecessário explicar aos produtores o que é custo variável, direto ou indireto, ou mesmo tentar diferenciar custo de despesa; os produtores rurais, em sua maioria, não possuem conhecimento destes termos ou não estão habituados ao seu funcionamento prático. Para que o planejamento obtenha sucesso junto às empresas agropecuárias, ele necessita ser realizado de forma sistemática e simplificada; caso contrário a grande maioria dos produtores rurais não conseguirá entendê-lo.

No que diz respeito à organização da empresa agropecuária, Canziani (2001) conclui que a maior parte dos esforços é direcionada para a área de produção. Isto é compreensível, pois uma boa organização da produção é uma condição fundamental para o sucesso do empreendimento agropecuário. A organização financeira fica comprometida devido à dificuldade de compreensão dos instrumentos disponíveis, tanto de ferramentas de fluxo de caixa simplificado, até dos pacotes tecnológicos (softwares). No que diz respeito à área de recursos humanos, a principal dificuldade referente à organização foi indicada pelo autor como sendo o excesso de concentração de poder e atividades na figura do proprietário rural. 
Por meio da direção o proprietário rural procura motivar seus empregados delegando responsabilidades, possibilitando o desenvolvimento dentro de empresa e demonstrando reconhecimento pelos resultados alcançados. A troca de informações, experiências e a transmissão de ordens são recursos utilizados para o desempenho desta função. Uma vez que a maioria das propriedades rurais é do tipo familiar, é fundamental a participação de todos os seus membros (proprietário(s), familiares e empregados) no processo decisório e na implantação do que foi decidido. Isto gera maior envolvimento e dedicação na hora de transformar em realidade o que foi planejado. A direção é também responsável pelo destino do lucro obtido pela empresa rural, que poderá ser repartido entre os sócios ou reinvestido na própria propriedade. A proporção destes montantes irá determinar a expansão dos negócios, ou aumentar o grau de dependência da empresa de outras fontes de recursos.

O controle deve ser bastante flexível, de modo a atender à necessidade de informações para a tomada de decisões na empresa agropecuária. Para que o controle seja realmente efetivo existem algumas ferramentas de apoio, tais como os registros contábeis e zootécnicos, livros de pessoal (demonstrando a rotatividade de empregados), controle financeiro e bancário e registros comerciais e fiscais.

O produtor rural desempenha as atividades administrativas quando toma decisões, realiza ações para a execução do que foi objetivado, toma atitudes diante de imprevistos ou de dificuldades e aceita a responsabilidade dos resultados finais atingidos. Guerra (1992) sintetiza teoricamente as principais atividades desempenhadas dentro de uma propriedade rural, relacionando-as a cada uma das funções administrativas: planejamento, organização, direção e controle. Muito embora o trabalho de Guerra compreenda uma boa revisão, o autor não aprofunda sua discussão sobre as interações entre as diferentes 
funções, aplicadas às áreas de atuação da empresa rural. Canziani (2001) amplia esta abordagem, incorporando os dois níveis de visão (operacional e estratégica), aplicadas a cada uma das diferentes áreas administrativas (produção, finanças, comercialização e recursos humanos). Ressalta, entretanto, que o administrador rural não percebe com clareza a separação entre as áreas ou mesmo entre as atividades por ele desenvolvidas. Isto porque realiza muitas atividades ao mesmo tempo, gerando interdependência entre elas, sem seguir um roteiro pré definido. Como síntese de suas idéias apresenta um quadro (reproduzido nos Quadros 1 e 2) no qual expõe exemplos genéricos de atividades administrativas realizadas em empresas agropecuárias.

Os benefícios da administração para o desempenho econômico de propriedades rurais foi investigado nos trabalhos de Phillips \& Peterson (1999) ${ }^{7}$ e Miller et al. (1998) ${ }^{8}$, citados por Canziani (2001). Os autores avaliam a utilização do planejamento estratégico na condução de propriedades rurais, concluindo que aqueles produtores que utilizam plenamente as funções administrativas e gerenciais com competência obtém melhores resultados na gestão de seus negócios. Desta forma, dentro de um grupo de produtores rurais sujeitos à condições produtivas muito próximas ou às mesmas variações exógenas, pode-se observar desempenhos econômicos diferentes.

7 PHILLIPS, J.C.; PETERSON, H.C. Strategic planning and firm performance: a proposed theoretical model for small agribusiness firms. East Lansing: Michigan State University, 1999. 15p. (Staff Paper, 99-41)

8 MILLER, A.; BOEHLJE, M.; DOBBINS, C. Positioning the farm business. West Lafayette: Purdue University, 1998. 37p. (Staff Paper, 98-9) 


\begin{tabular}{|c|c|c|}
\hline $\begin{array}{l}\text { ÁREA ADMINISTRATIVA } \\
\text { ANCÕ }\end{array}$ & PRODUÇÃO & FINANÇAS \\
\hline $\begin{array}{l}\text { PLANEJAMENTO } \\
\text { ESTRATÉGICO }\end{array}$ & $\begin{array}{l}\text { 1. Identificar e definir as atividades } \\
\text { (culturas e criações) a serem realizadas } \\
\text { pela empresa, considerando fatores } \\
\text { como: as disponibilidades e as } \\
\text { exigências de recursos; os riscos e as } \\
\text { rentabilidades potenciais; as ameaças e } \\
\text { as oportunidades do ambiente; e os } \\
\text { gostos e as preferências do produtor } \\
\text { rural e sua família. } \\
\text { 2. Projetar o desempenho produtivo da } \\
\text { empresa e a alocação dos recursos } \\
\text { necessários a produção. }\end{array}$ & $\begin{array}{l}\text { 1. Projetar o fluxo de caixa das } \\
\text { atividades e da empresa como um todo } \\
\text { (incluindo gastos familiares), } \\
\text { especificando as origens (fontes) e as } \\
\text { aplicações (usos) dos recursos } \\
\text { financeiros. } \\
\text { 2. Elaborar e analisar a viabilidade de } \\
\text { projetos de investimento para a } \\
\text { implantação de novas atividades ou } \\
\text { para a modificação/alteração do atual } \\
\text { sistema de produção. }\end{array}$ \\
\hline $\begin{array}{l}\text { PLANEJAMENTO } \\
\text { OPERACIONAL }\end{array}$ & $\begin{array}{l}\text { 1. Definir o sistema de produção } \\
\text { (tecnologia) e estabelecer metas de } \\
\text { produção e produtividade. } \\
\text { 2. Estabelecer cronograma físico das } \\
\text { tarefas e operações para cada uma das } \\
\text { atividades da empresa. }\end{array}$ & $\begin{array}{l}\text { 1. Elaborar orçamentos para as } \\
\text { atividades da empresa. } \\
\text { 2. Estabelecer cronograma financeiro } \\
\text { para as atividades da empresa. }\end{array}$ \\
\hline $\begin{array}{l}\text { ORGANIZAÇÃO } \\
\text { ESTRATÉGICA }\end{array}$ & $\begin{array}{l}\text { 1. Dispor, ordenadamente, a } \\
\text { exploração dos campos e a localização } \\
\text { das benfeitorias na empresa. } \\
\text { 2. Definir sobre as formas de } \\
\text { organização da produção na empresa } \\
\text { (individual, societária, parceria, } \\
\text { arrendamento, etc.). }\end{array}$ & $\begin{array}{l}\text { 1. Definir os centros de custos e/ou } \\
\text { centros de lucros da empresa. } \\
\text { 2. Definir e detalhar o plano de contas } \\
\text { da empresa. }\end{array}$ \\
\hline $\begin{array}{l}\text { ORGANIZAÇÃO } \\
\text { OPERACIONAL }\end{array}$ & $\begin{array}{l}\text { 1. Organizar e sistematizar o uso } \\
\text { cotidiano dos capitais fixos e circulantes } \\
\text { da empresa. } \\
\text { 2. Definir sobre a contratação de } \\
\text { serviços de terceiros. }\end{array}$ & $\begin{array}{l}\text { 1. Organizar e sistematizar o fluxo de } \\
\text { informações financeiras da empresa. } \\
\text { 2. Definir a forma de armazenamento } \\
\text { de dados e de processamento das } \\
\text { informações financeiras. }\end{array}$ \\
\hline $\begin{array}{c}\text { DIREÇÃO } \\
\text { ESTRATÉGICA }\end{array}$ & $\begin{array}{l}\text { 1. Supervisionar as atividades } \\
\text { produtivas para o alcance dos objetivos } \\
\text { da empresa. } \\
\text { 2. Supervisionar o uso dos bens de } \\
\text { capital fixo e circulante da empresa. }\end{array}$ & $\begin{array}{l}\text { 1. Definir e supervisionar os usos dos } \\
\text { recursos financeiros próprios e de } \\
\text { terceiros na empresa. } \\
\text { 2. Administrar as finanças da empresa, } \\
\text { decidindo sobre gastos ou poupanças e } \\
\text { sobre aplicações ou contratações de } \\
\text { recursos financeiros. }\end{array}$ \\
\hline $\begin{array}{c}\text { DIREÇÃO } \\
\text { OPERACIONAL }\end{array}$ & $\begin{array}{l}\text { 1. Comandar e acompanhar o processo } \\
\text { produtivo. } \\
\text { 2. Determinar as tarefas e operações a } \\
\text { serem realizadas para o bom } \\
\text { andamento da produção. }\end{array}$ & $\begin{array}{l}\text { 1. Executar o cronograma financeiro da } \\
\text { empresa. } \\
\text { 2. Gerenciar cotidianamente o fluxo de } \\
\text { caixa da empresa. }\end{array}$ \\
\hline $\begin{array}{l}\text { CONTROLE } \\
\text { ESTRATÉGICO }\end{array}$ & $\begin{array}{l}\text { 1. Coletar e sistematizar dados } \\
\text { relacionados à produção global da } \\
\text { empresa. } \\
\text { 2. Avaliar a empresa como um todo sob } \\
\text { o aspecto produtivo. }\end{array}$ & $\begin{array}{l}\text { 1. Coletar e sistematizar dados } \\
\text { relacionados às finanças da empresa } \\
\text { como um todo, detalhando as origens } \\
\text { (fontes) e aplicações (usos) dos } \\
\text { recursos financeiros. } \\
\text { 2. Avaliar a empresa como um todo nos } \\
\text { aspectos econômicos e financeiros. }\end{array}$ \\
\hline $\begin{array}{l}\text { CONTROLE } \\
\text { OPERACIONAL }\end{array}$ & $\begin{array}{l}\text { 1. Coletar e sistematizar dados } \\
\text { relacionados às atividades produtivas } \\
\text { da empresa e ao uso dos capitais fixos } \\
\text { e circulantes. } \\
\text { 2. Avaliar individualmente as atividades } \\
\text { da empresa sob o aspecto produtivo e } \\
\text { quanto ao uso dos capitais fixos e } \\
\text { circulantes. }\end{array}$ & $\begin{array}{l}\text { 1. Coletar e sistematizar dados } \\
\text { econômicos e financeiros das } \\
\text { atividades desenvolvidas pela empresa. } \\
\text { 2. Avaliar individualmente as atividades } \\
\text { da empresa sob os aspectos } \\
\text { econômico e financeiro. }\end{array}$ \\
\hline
\end{tabular}

Quadro 1 - Identificação de atividades administrativas realizadas em empresas agropecuárias. Dois exemplos genéricos de atividades administrativas para cada uma das diferentes funções do processo administrativo - aplicação às áreas de produção e finanças.

Fonte: adaptado de Canziani (2001, p.50-53). 


\begin{tabular}{|c|c|c|}
\hline $\begin{array}{c}\text { ÁREA ADMINISTRATIVA } \\
\text { FUNÇŌES ADMINISTRATIVAS }\end{array}$ & COMERCIALIZAÇÃO & $\begin{array}{l}\text { RECURSOS } \\
\text { HUMANOS }\end{array}$ \\
\hline $\begin{array}{l}\text { PLANEJAMENTO } \\
\text { ESTRATÉGICO }\end{array}$ & $\begin{array}{l}\text { 1. Identificar e definir estratégias de } \\
\text { comercialização (compras e vendas) } \\
\text { para todas as atividades da empresa. } \\
\text { 2. Estimar preços futuros de médio e } \\
\text { longo prazo para insumos e produtos } \\
\text { e definir canais de comercialização. }\end{array}$ & $\begin{array}{l}\text { 1. Estimar o balanço de oferta e } \\
\text { demanda de mão-de-obra para a } \\
\text { empresa. } \\
\text { 2. Definir a estratégia da empresa } \\
\text { para a seleção, recrutamento e } \\
\text { treinamento da mão-de-obra. }\end{array}$ \\
\hline $\begin{array}{l}\text { PLANEJAMENTO } \\
\text { OPERACIONAL }\end{array}$ & $\begin{array}{l}\text { 1. Estabelecer planos para a } \\
\text { comercialização (compras e vendas) } \\
\text { no curto prazo. } \\
\text { 2. Estimar preços futuros de curto } \\
\text { prazo para insumos e produtos. }\end{array}$ & $\begin{array}{l}\text { 1. Prever a disponibilidade e } \\
\text { exigência de mão-de-obra para as } \\
\text { atividades da empresa. } \\
\text { 2. Estabelecer para a mão-de-obra as } \\
\text { ações necessárias para a execução } \\
\text { dos planos de produção. }\end{array}$ \\
\hline $\begin{array}{l}\text { ORGANIZAÇÃO } \\
\text { ESTRATÉGICA }\end{array}$ & $\begin{array}{l}\text { 1. Definir e sistematizar } \\
\text { estratégias de compra de insumos e } \\
\text { outros fatores de produção. } \\
\text { 2. Definir e sistematizar } \\
\text { estratégias para a venda } \\
\text { produção. }\end{array}$ & $\begin{array}{l}\text { 1. Estabelecer o organograma } \\
\text { funcional (atribuições) da mão-de- } \\
\text { obra, indicando a interdependência e } \\
\text { a hierarquia entre as pessoas, as } \\
\text { seções ou áreas de } \\
\text { responsabilidades existentes na } \\
\text { empresa. } \\
\text { 2. Estabelecer planos de cargos e } \\
\text { salários para a mão-de-obra. }\end{array}$ \\
\hline $\begin{array}{l}\text { ORGANIZAÇÃO } \\
\text { OPERACIONAL }\end{array}$ & $\begin{array}{l}\text { 1. Organizar sistemas para a } \\
\text { identificação e seleção de clientes e } \\
\text { de fornecedores de bens e serviços. } \\
\text { 2. Organizar sistemas para o } \\
\text { acompanhamento de preços no } \\
\text { tempo e no espaço. }\end{array}$ & $\begin{array}{l}\text { 1. Distribuir adequadamente no } \\
\text { tempo e no espaço as tarefas da } \\
\text { mão-de-obra. } \\
\text { 2. Estabelecer responsabilidades } \\
\text { cotidianas e padrões de desempenho } \\
\text { para a mão-de-obra. }\end{array}$ \\
\hline $\begin{array}{c}\text { DIREÇÃO } \\
\text { ESTRATÉGICA }\end{array}$ & $\begin{array}{l}\text { 1. Executar a estratégia de compra } \\
\text { de insumos e venda da produção. } \\
\text { 2. Estabelecer relacionamentos } \\
\text { (comunicação) com clientes e } \\
\text { fornecedores de bens e serviços. }\end{array}$ & $\begin{array}{l}\text { 1. Promover a seleção, treinamento e } \\
\text { desenvolvimento da mão-de-obra. } \\
\text { 2. Definir formas de comunicação e } \\
\text { liderança na empresa }\end{array}$ \\
\hline $\begin{array}{c}\text { DIREÇÃO } \\
\text { OPERACIONAL }\end{array}$ & $\begin{array}{l}\text { 1. Decidir e realizar as compras de } \\
\text { insumos e outros fatores de } \\
\text { produção. } \\
\text { 2. Decidir e realizar as vendas da } \\
\text { produção. }\end{array}$ & $\begin{array}{l}\text { 1. Dar ordens de serviço à mão-de- } \\
\text { obra e monitorar o cumprimento das } \\
\text { tarefas. } \\
\text { 2. Motivar os trabalhadores. }\end{array}$ \\
\hline $\begin{array}{l}\text { CONTROLE } \\
\text { ESTRATÉGICO }\end{array}$ & $\begin{array}{l}\text { 1. Coletar e sistematizar dados } \\
\text { relacionados a comercialização } \\
\text { (compras e vendas) da empresa no } \\
\text { médio e longo prazo. } \\
\text { 2. Avaliar a empresa como um todo } \\
\text { no aspecto da comercialização. }\end{array}$ & $\begin{array}{l}\text { 1. Coletar e sistematizar dados } \\
\text { relacionados aos recursos humanos } \\
\text { da empresa como um todo. } \\
\text { 2.Avaliar a empresa como um todo no } \\
\text { aspecto dos recursos humanos. }\end{array}$ \\
\hline $\begin{array}{l}\text { CONTROLE } \\
\text { OPERACIONAL }\end{array}$ & $\begin{array}{l}\text { 1. Coletar e sistematizar dados } \\
\text { relacionados a comercialização no } \\
\text { ano safra. } \\
\text { 2. Avaliar individualmente as } \\
\text { atividades da empresa sob o aspecto } \\
\text { da comercialização. }\end{array}$ & $\begin{array}{l}\text { 1. Coletar e sistematizar dados } \\
\text { relacionados aos recursos humanos } \\
\text { nas atividades da empresa. } \\
\text { 2.Avaliar as atividades da mão-de- } \\
\text { obra na empresa. }\end{array}$ \\
\hline
\end{tabular}

Quadro 2 - Identificação de atividades administrativas realizadas em empresas agropecuárias. Dois exemplos genéricos de atividades administrativas para cada uma das diferentes funções do processo administrativo - aplicação às áreas de comercialização e recursos humanos.

Fonte: adaptado de Canziani (2001, p.50-53). 
No Brasil, alguns estudos como o de Mendonça (1996) também analisam a questão das funções administrativas. A autora conclui que dentre os fatores que contribuem para o sucesso de um empreendimento rural, muito é devido à habilidade gerencial do proprietário. O trabalho considerou um grupo de produtores rurais associados à Cooperativa Agrícola Alto Rio Grande Ltda., localizada no município de Lavras (MG). O diferencial encontrado em termos dos resultados técnicos e econômicos foi atribuído ao desempenho administrativo do produtor rural. Este deve ser entendido não somente como a dedicação às tarefas rotineiras e à interligação com os empregados, mas envolve elementos como a visão sistêmica do processo produtivo e a maleabilidade ou flexibilidade na gestão. Entretanto, a autora considerou em seu estudo um número reduzido de produtores rurais, o que dificulta a generalização de suas conclusões. Observa-se também que o trabalho foi dirigido para a análise de somente duas funções administrativas, desconsiderando-se a organização e o controle.

Basso (1993) centra sua análise nas funções de controle e direção, ao estudar uma associação de pequenos agricultores no Rio Grande do Sul. Conclui que somente por meio de uma estrutura administrativa funcional, com procedimentos específicos para a tomada de decisões, análise de viabilidade de projetos e gestão de recursos financeiros e humanos, é possível melhorar o desempenho econômico de todos os produtores associados.

Muito embora destacado em teoria como um dos fatores que contribui positivamente para a obtenção de resultados técnicos e econômicos, a capacitação do administrador rural depende fundamentalmente da competência gerencial deste. Pouco contribui o conhecimento teórico sobre administração, se considerado isoladamente; a competência envolve também as habilidades e atitudes diante das decisões a serem tomadas. 
A competência gerencial pode ser definida, então, como as qualificações decorrentes do conhecimento que o administrador tem sobre suas atribuições e suas aptidões e habilidades além das atitudes que precisa ter para enfrentar um negócio com características especiais de funcionamento em um setor altamente competitivo. Para Maximiano (1995) competência é o conjunto de qualificações que uma pessoa deve possuir, adquirir ou desenvolver para ocupar o cargo em qualquer empreendimento, rural ou não. A competência gerencial depende então, do conhecimento, das habilidades e das atitudes.

O conhecimento é o ato ou efeito de compreender as propriedades e as características do processo administrativo a fim de aplicá-lo na condução da empresa rural. Fazem parte do conhecimento as técnicas, informações, experiência, o tino e a prática que o administrador possui, de modo a exercer suas atividades ou negócios. A competência técnica, o conhecimento das funções administrativas e o entendimento do ciclo de vida de uma empresa e do sistema agropecuário são informações que devem fazer parte do conjunto de conhecimentos do administrador rural.

A competência técnica na agropecuária refere-se ao conhecimento das atividades de produção. O conhecimento das funções administrativas exige a capacidade de planejar as ações a serem executadas no curto e longo prazo, organizar as atividades da empresa, dirigir as atividades para atingir os objetivos propostos e controlar a produção e as finanças através de sistemas que possibilitem medir e comparar o desempenho conforme o planejado. $O$ entendimento do ciclo de vida de um projeto é importante para uma visualização do início e do fim daquilo que deve ser executado, permitindo prever e evitar problemas na sua execução. A compreensão do sistema agropecuário possibilita o conhecimento dos sistemas institucionais e humanos exógenos (mercado consumidor, sistemas de mercado, normas e crenças sociais, políticas agrícolas e oportunidades fora do meio rural) e endógenos à 
propriedade. O conhecimento é a base do desenvolvimento das habilidades. Portanto, quanto mais conhecimento tem-se, maior a capacidade de discernimento e de compreensão dos fenômenos que ocorrem nos sistemas agropecuários.

A habilidade é a capacidade, destreza e agilidade no desenvolvimento de uma atividade; é a qualidade que torna o administrador rural apto e capaz de realizar uma boa administração, tornando a propriedade funcional e viável. Fazem parte das habilidades a capacidade de definir estratégias, analisar problemas e de se relacionar com as pessoas. Maximiano (1997) acrescenta a esta lista a clareza na comunicação com superiores e subordinados, a capacidade de delegar atividades, a transmissão e obtenção de apoio e confiança, a empatia, a adaptação a diferentes contextos e a capacidade de negociação.

Analisando a habilidade aplicada à agropecuária, Andrade (1996) dividea em três categorias: técnica, humana e conceitual. A habilidade técnica é a aplicação prática dos conhecimentos adquiridos no processo produtivo; a habilidade humana decorre da interação que as pessoas mantém no trabalho e a habilidade conceitual é a capacidade que o administrador rural tem em visualizar sua propriedade rural como empresa onde se desempenha 0 processo administrativo. Ao contrário do conhecimento, que pode ser adquirido em cursos, leituras e por simples transmissão oral, a habilidade depende de um processo vivencial ou experimental e é o resultado da aplicação prática dos conhecimentos adquiridos.

A atitude é a ação, conduta ou procedimento do administrador frente a uma situação favorável ou desfavorável no exercício de suas atribuições. É o resultado da aplicação do conhecimento adquirido tendo em vista a personalidade de cada indivíduo diante de uma situação a ser resolvida. Para 
Maximiano (1995) "as atitudes formam os quadros de referências, isto é, as molduras valorativas dentro das quais as pessoas, fatos, idéias e objetos são vistos, interpretados e avaliados".

Para que seja possível a um indivíduo exercer determinada ação ou conduta, é necessário motivação para fazê-lo, como forma de ampliar o interesse e a dedicação. Além da motivação o administrador deve assumir responsabilidades, sentindo-se confortável com as diferentes situações que terá que enfrentar. Deve também motivar as pessoas envolvidas com a atividade e disseminar suas idéias, controlando ao mesmo tempo o pessimismo ou excesso de confiança.

\subsubsection{A administração e os objetivos dos produtores rurais}

As primeiras tentativas de compreensão da função otimizada pelo empresário rural consideravam como seu objetivo a maximização do lucro, seguindo os preceitos da microeconomia neoclássica. Foram desconsiderados aspectos relacionados às características pessoais do produtor, como a situação familiar e o ciclo de vida pessoal e da exploração produtiva. Também não foram levadas em conta a capacidade e a disposição para a mudança, tendo em vista a adaptação da infra-estrutura aos novos processos produtivos, os custos pessoais em termos de aprendizagem e de saída das atividades.

Miranda (1998, p.2) lembra que dentre os objetivos do produtor rural, deve-se considerar não somente o desenvolvimento econômico fundamentado no "crescimento agrícola - principal base produtiva do meio rural, mas sim num equilíbrio entre o desenvolvimento econômico, o humano e o social". Assim a administração rural não pode deixar de visar a melhoria do bem-estar e da renda líquida familiar, o aumento no valor do patrimônio e a manutenção de uma imagem satisfatória do produtor rural perante a sociedade. 
Para Sebillote (1988), a compreensão parcial dos horizontes dos produtores rurais, levou a insistentes falhas na assistência técnica prestada e na aplicação de planos de desenvolvimento padronizados. Ressaltou que somente o amplo entendimento dos objetivos dos agricultores poderia melhorar a prestação de assistência técnica. Nix (1979) menciona o fato de que a qualidade de vida do produtor rural não está diretamente relacionada somente com a maximização do lucro. O desconhecimento dos reais objetivos dos produtores leva ao distanciamento dos trabalhos teóricos daqueles efetivamente aplicáveis à atividade produtiva.

Neste sentido, o trabalho de Dalmazo \& Albertoni (1991) chama a atenção para a multiplicidade de objetivos pessoais dos produtores rurais, conforme pesquisa no oeste catarinense em meados de 1988. Contrariando a idéia de "maximização de lucros" como objetivo primordial (mencionado somente por $9 \%$ dos entrevistados), observa-se que $71 \%$ dos agricultores tem por objetivo "permanecer no campo", 17\% querem "adquirir mais terras para os filhos" e 3\% preocupam-se em "não ter mais dívidas". Apesar dos resultados encontrados na pesquisa direta, é preciso salientar que estas respostas não são incompatíveis com a maximização do lucro. Estes resultados chamam a atenção, principalmente quando comparados com a visão de extensionistas sobre quais seriam os objetivos dos agricultores. Para a equipe de extensão pesquisada, $50 \%$ dos produtores objetivam "aumentar a renda e/ou garantir o futuro dos filhos", $27 \%$ visam simplesmente a "sobrevivência", $8 \%$ a "permanência na lavoura" e $8 \%$ "ter boa terra e conservar o solo".

Uma das razões para a divergência entre os objetivos indicados pelos produtores e extensionistas pode ser atribuída à falta de preparo dos técnicos 
em lidar com as expectativas e anseios dos agricultores. Olinger $(1984)^{9}$, citado por Canziani (2001), destaca a formação deficiente dos profissionais em ciências agrárias em aspectos práticos relativos à administração rural. Analisando os currículos escolares ele sugere que há, nestes cursos, comprovada ênfase na parte técnica. Percebe-se que as disciplinas relacionadas à administração rural têm caráter meramente informativo e não aplicado à formação prática. Conforme Noronha \& Peres (1992), a preocupação excessiva com aspectos técnicos distanciou-os das disciplina de administração rural, uma vez que é atribuído destaque às tecnologias de produção e não à aplicação dos conhecimentos administrativos. Isto pode ser demonstrado através da dificuldade ou do uso inadequado de muitas ferramentas ou estratégias de gerenciamento no meio rural brasileiro, por parte dos produtores e dos técnicos. A experiência acumulada do proprietário e certo grau de empirismo acabam por determinar a forma de administração da propriedade agrícola. Assim, Dalmazo \& Albertoni (1991) concluem que a falta de sintonia entre as visões dos extensionistas e dos produtores rurais pode ser compreendida como uma das explicações para o perfil conservador destes últimos ao preterirem muitas vezes a opinião dos técnicos.

${ }^{9}$ OLINGER, G. Como melhorar a eficácia da extensão rural no Brasil e na América Latina. Brasília: EMBRATER, 1984. 52p. (Série Leituras Selecionadas, 13) 


\section{METODOLOGIA}

Diante do objetivo de melhor compreender a capacidade administrativa dos bons produtores rurais, essa pesquisa fez uso de dados primários, levantados diretamente junto a produtores associados à Cooperativa Tritícola Mista Alto Jacuí Ltda. (Cotrijal) e técnicos desta Cooperativa que os assistem. A coleta dos dados foi feita, inicialmente, mediante entrevistas grupais. O objetivo deste primeiro levantamento foi tentar sistematizar o pensamento corrente dos associados e dos técnicos a respeito das principais características de um bom produtor rural.

Após a explicitação dos elementos que os produtores e técnicos consideram importantes na definição de um bom produtor, através da análise dos dados obtidos nos grupos focais, a etapa seguinte compreendeu a elaboração de um questionário, que refletisse as opiniões levantadas na fase inicial, buscando compatibilizá-las com as funções administrativas descritas teoricamente. O levantamento dos dados compreendeu a aplicação de questionário, realizado em duas etapas. Na primeira fase, os questionários foram respondidos por produtores rurais, escolhidos aleatoriamente dentre os associados à Cotrijal. Diante das respostas obtidas, foi possível transformar fatores qualitativos, considerados como "atributos de um bom produtor rural" em fatores quantitativos, conduzindo à análise estatística dos resultados. 
$\mathrm{Na}$ segunda fase do processo de entrevistas, os produtores rurais entrevistados na primeira etapa foram relacionados em uma tabela e esta lista apresentada a uma parcela dos produtores associados à Cooperativa e à equipe de assistência técnica. Foi solicitado a estes que atribuíssem nota, entre zero e dez, à capacidade administrativa dos produtores conhecidos que estivessem relacionados na lista.

Neste capítulo, apresenta-se a metodologia utilizada na pesquisa de campo. O item 3.1 apresenta breves considerações a respeito da Cotrijal, cooperativa cujos associados foram escolhidos como amostra para a resposta dos questionários. No item 3.2 é descrita a técnica qualitativa utilizada na pesquisa e nos itens 3.3 e 3.4 as técnicas quantitativas de coleta e análise dos dados. ${ }^{10} \mathrm{Na}$ abordagem qualitativa descreve-se a técnica de "grupos focais" utilizada para identificar as características de um bom produtor rural. $\mathrm{Na}$ abordagem quantitativa descreve-se inicialmente como foram estruturados os questionários, a fim de quantificar a opinião e percepção dos produtores rurais e profissionais da assistência técnica sobre questões relacionadas à administração das empresas agropecuárias. Tendo em vista o número elevado de variáveis consideradas (trinta e duas, correspondentes às 32 atividades administrativas a serem desempenhadas), foi necessária a utilização da metodologia de "análise fatorial". O método é parte da análise multivariada de dados, que permite a redução de um número elevado de variáveis em um número menor de variáveis hipotéticas denominadas "fatores" que não são correlacionados entre si.

\footnotetext{
${ }^{10} \mathrm{O}$ método econométrico de análise de regressão não foi descrito neste trabalho, uma vez que é amplamente conhecido e é propriamente comentado em vários livros texto sobre o assunto.
} 


\subsection{Caracterização da Cooperativa Tritícola Mista Alto Jacuí Ltda. ${ }^{11}$}

A caracterização do sucesso de um produtor rural foi feita através de pesquisa realizada junto aos associados à Cooperativa Tritícola Mista Alto Jacui Ltda. (Cotrijal). A Cotrijal foi constituída em 14 de setembro de 1957 por produtores rurais de origem alemã, com sede e administração no município de Não-Me-Toque, estado do Rio Grande do Sul. Além do município sede, atualmente a área de ação para efeito de admissão de associados, abrange os municípios de Carazinho, Chapada, Colorado, Coqueiros do Sul, Ernestina, Espumoso, Ibirapuitã, Ibirubá, Lagoa dos Três Cantos, Mormaço, Nicolau Vergueiro, Nova Boa Vista, Palmeiras das Missões, Passo Fundo, Ronda Alta, Saldanha Marinho, Santa Bárbara do Sul, Santo Antônio do Planalto, Sarandi, Selbach, Soledade, Tapera, Três Palmeiras, Victor Graeff e XV de Novembro.

A região de abrangência das atividades da Cooperativa localiza-se na macrorregião norte do estado, na região conhecida como Alto Jacuí. Esta região possui solos ácidos, do tipo roxo distrófico e álico, necessitando de constantes correções do nível de acidez. Possuem também teor de argila que varia entre $40 \%$ a $60 \%$ (argiloso); $26,2 \%$ dos solos analisados na região constataram $\mathrm{PH}\left(\mathrm{CaCl}_{2}\right)$ entre 5,0 e 5,4; no restante foi encontrado $\mathrm{PH}$ inferior a 5,0 , confirmando acidez média elevada no solo.

De acordo com a classificação Köeppen, a região de atuação da Cotrijal possui clima subtropical, sem predominância de estação seca definida. O verão é considerado ameno, com temperaturas máximas inferiores a $21^{\circ} \mathrm{C}$. Os meses de dezembro e janeiro são considerados os mais quentes do ano (média acima de $30^{\circ} \mathrm{C}$ ), em contraponto aos meses mais frios (junho, julho e agosto), com temperaturas mínimas próximas de $0^{\circ} \mathrm{C}$. Os meses mais chuvosos, por sua vez, são maio, dezembro e outubro (média de $190 \mathrm{~mm} /$ mês); as menores

${ }^{11}$ Conforme dados de Cotrijal (2002) e Jornal da Cotrijal (2001). 
precipitações ocorrem nos meses de agosto, março e abril (média mínima de $110 \mathrm{~mm} / \mathrm{mês})$.

Após sua fundação, a Cotrijal contou com apoio do Governo Federal que, através do Ministério da Agricultura, estabeleceu experimentos em diferentes locais na região, testando diferentes variedades de trigo em várias épocas do ano, com o intuito de verificar qual a alternativa para a produção mais rentável. Ao mesmo tempo, testes foram feitos com o objetivo de aumentar a fertilidade do solo, considerado pobre em nutrientes. Com o sucesso desta empreitada, a região consolidou-se já na década de 1970, na produção de trigo, além de outros grãos como o milho e a soja. Visando diminuir os efeitos nocivos da erosão, motivada muitas vezes pelo sistema tradicional de produção de grãos, o plantio direto passou a ser utilizado na década seguinte. Em que pese tais esforços, a produtividade média dos associados à Cotrijal era considerada baixa. Segundo dados referentes ao ano de 1985, a produtividade média da região resultava em $1920 \mathrm{~kg} / \mathrm{ha}$ para a cevada, $2100 \mathrm{~kg} / \mathrm{ha}$ para a soja, 2200 $\mathrm{kg} / \mathrm{ha}$ para o trigo e cerca de $1850 \mathrm{~kg} / \mathrm{ha}$ para a aveia.

Na década de 1990 a Cooperativa intensificou o treinamento fornecido a seus associados e a experimentação científica. Como parte deste projeto, foram promovidos "dias de campo" (visitas aos produtores rurais visando a divulgação de novas técnicas de plantio/cultivo ou variedades de culturas), visitas a outras regiões agrícolas do Brasil e do exterior e palestras técnicas. O resultado deste esforço foi o aumento de produtividade nas principais culturas desenvolvidas pelos associados à Cotrijal. Considerando-se um período médio de cinco anos, verificou-se a produtividade de $2500 \mathrm{~kg} / \mathrm{ha}$ para a aveia, cerca de $3000 \mathrm{~kg} / \mathrm{ha}$ para a cevada, $2700 \mathrm{~kg} / \mathrm{ha}$ para o trigo, $2800 \mathrm{~kg} / \mathrm{ha}$ para a soja e acima de $7.000 \mathrm{~kg} / \mathrm{ha}$ para o milho. 
Conforme dados de Cotrijal (2002), atualmente a Cooperativa possui corpo associativo formado por cerca de 3.000 produtores rurais, que concentra sua produção nas culturas de aveia, cevada, trigo (culturas de inverno), soja e milho (culturas de verão), perfazendo um total de cerca de 50 mil hectares plantados anualmente. Além destas, a produção animal, sobretudo leite e suinocultura, são atividades desenvolvidas pelos associados.

As atividades da Cooperativa concentram-se na produção (a Cotrijal é auto-suficiente em sementes), armazenagem, industrialização e comercialização de insumos produtivos. No exercício 2000/ 2001, as transações com grãos representaram $83,47 \%$ do faturamento bruto de $\mathrm{R} \$ 214,7$ milhões da Cooperativa conforme o Jornal da Cotrijal (2001) do mês de julho de 2001 enquanto a produção animal colaborou com 8,05\%. Os restantes $8,48 \%$ couberam a atividade de varejo. Assim, a Cooperativa procura incrementar a capacidade de armazenagem de grãos, que atualmente ultrapassa 6 milhões de sacas. Esta estratégia de comercialização evita a submissão de grandes volumes de grãos à indústria processadora, ao mesmo tempo que melhora as condições de negociação.

Como forma de auxiliar seus cooperados no controle de receitas, custos e despesas e no cálculo do lucro efetivamente incorrido em cada atividade produtiva por eles desenvolvidas, a Cotrijal lançou o "programa de gerenciamento", envolvendo cerca de 210 produtores associados. O objetivo do programa é o mapeamento dos aspectos econômicos e financeiros das diferentes atividades realizadas, por meio da utilização de uma ferramenta simplificada de administração de fluxo de caixa. 


\subsection{A técnica de "grupos focais"}

O "grupo focal" é um método de pesquisa proposto e aplicado pela primeira vez para avaliar o potencial da propaganda durante a Segunda Guerra Mundial (Westphal et al., 1996). A partir desta utilização inicial, este método passou a ser utilizado sobretudo em ciências humanas e sociais aplicadas, tais como a mercadologia, psicologia, ciências sociais, saúde pública e educação em saúde, tendo em vista a facilidade de obtenção de dados qualitativos com certo nível de profundidade e em curto período de tempo. O grupo focal é uma técnica de pesquisa qualitativa que pode ser associada a uma "entrevista" realizada com grupos de pessoas e que segue alguns critérios previamente estabelecidos conforme seu propósito, tamanho, composição e dinâmica. ${ }^{12}$

Durante a realização da sessão do grupo focal, os participantes não restringem sua participação a simples respostas às questões formuladas. É fundamental a discussão a respeito do tópico exposto e a concordância ou não entre as partes, bem como o posicionamento dos participantes, com base nas perspectivas e experiências pessoais. Esta técnica propicia a coleta de dados a partir da interação dos indivíduos; os resultados obtidos provêem da discussão coletiva de determinado tema que faz parte da vida de todos os participantes. Ao serem expostas a uma discussão em grupo, as pessoas podem formular e expor suas percepções assim como fundamentar melhor a própria opinião ou mudá-la no transcorrer da sessão.

A técnica do grupo focal apresenta as seguintes passos: (a) definição do problema a ser discutido e dos objetivos da sessão; (b) escolha da equipe de trabalho constituída por um "moderador", um "observador" e, se necessário, um

${ }^{12}$ Quanto a descrição do método de grupos focais, ver Bader \& Rossi (1999), Carlini-Cotrim (1996) e Westphal et al. (1996). Ver também CHIESA, A.M.; CIAMPONE, M.H.T. Princípios gerais para abordagem de variáveis qualitativas e o emprego da metodologia de grupos 
responsável pelas gravações; (c) elaboração e teste do roteiro de questões que deverão ser aplicadas; (d) definição da forma de registro do grupo focal (gravação em áudio, vídeo, estenografia, etc.), caso seja permitido pelos participantes; (e) determinação dos critérios para seleção dos participantes do grupo $^{13}$; (f) definição de local, data e horário ${ }^{14}$ que torne possível a presença dos participantes; e (g) escolha de ambiente com pouco ruído externo, de modo a não prejudicar as anotações e/ou a gravação da sessão.

Cabe ressaltar o papel e a importância do "moderador" do grupo focal. Peça fundamental ao sucesso do grupo, deve criar um ambiente propício, bem como encorajar os participantes a expressarem suas opiniões a respeito do assunto abordado. Para tanto, o moderador deve propor questões já preparadas e testadas anteriormente a respeito do tópico a ser abordado. Cabe a ele manter o foco da discussão, reconduzindo-a ao assunto debatido toda vez que ocorrerem desvios. É importante também para a solicitação de esclarecimentos a questões pouco claras, estímulo à participação de indivíduos mais retraídos e controle dos mais expansivos. Em suma, deve atuar de forma discreta, como um facilitador da exposição das opiniões dos participantes, realizando as inferências necessárias e as conclusões cabíveis. Ao "observador" cabe a função de tomar nota das opiniões expostas, das reações não verbais e da forma de como o moderador conduziu o grupo.

Ao final da sessão do grupo focal, as gravações devem ser transcritas. A síntese etnográfica, composta pelas citações textuais dos participantes, servem de base para a análise do conteúdo discutido. A análise das discussões transcritas facilita a compreensão do significado dos textos, com o objetivo de

focais. s.n.t. 19p. e PEREIRA, M.J.B.; FORTUNA, C.M.; MATUMOTO, S. et al. Grupo focal: experiência na coleta de dados do projeto CIPESC - Brasil. s.n.t. 14p.

${ }^{13}$ Os grupos são compostos, geralmente, por seis a 15 pessoas que tenham em comum certas características associadas ao assunto a ser pesquisado; a homogeneidade pretendida deve ser em termos de características pessoais, mas não com relação à percepção do assunto em foco.

${ }^{14} \mathrm{O}$ grupo focal deve ter a duração de uma hora e meia ou próximo a isto. 
abranger o verdadeiro significado dos testemunhos relatados. Não se pretende, com isto, questionar a posição ideológica do participante, mas sim entender como este vê o mundo e, portanto, reconhecer, interpretar e reinterpretar as concepções sobre determinado objeto. Busca-se o reconhecimento das encadeações e articulações entre os temas abordados, buscando identificar pontos de convergência ou dispersão entre as opiniões. Na seqüência, é realizada a recomposição das opiniões dos participantes, em frases temáticas que sintetizem o discurso do participante. Com isto, obtém-se o agrupamento dessas frases, facilitando a classificação do material empírico.

Os passos que compõem a análise de uma sessão de grupo focal devem ser realizados de forma independente pelo moderador e pelo observador, com o objetivo de extrair percepções autônomas sobre o problema enfocado. Em que pese os cuidados com a independência das opiniões e conclusões, recomendase que sejam realizados mais de um grupo focal a respeito do mesmo tópico, de modo a compreender e identificar se ocorre diferença de percepção ou compreensão entre os diferentes agrupamentos de pessoas.

O grupo focal, como técnica de pesquisa qualitativa, tem como vantagem a possibilidade de se atingir um maior número de pessoas ao mesmo tempo. É um intercâmbio do aprofundamento de uma entrevista individual pela troca de percepções entre os participantes a respeito do assunto enfocado. Possibilita também a obtenção de dados de forma mais rápida e com custos às vezes menores do que com a entrevista individual. Adicionalmente, é uma fonte preliminar de informações para a elaboração e teste de questionários, a serem utilizados em pesquisa quantitativa.

Entre os pontos menos vantajosos que podem ser citados na utilização de grupos focais está o fato do pesquisador ter menos controle do que com a entrevista individual, exigindo atenção adicional para que não ocorram desvios 
com relação ao assunto proposto. Há dificuldade para a generalização dos resultados obtidos e a análise realizada com base nas discussões realizadas podem conter indícios de opinião do próprio pesquisador, mesmo que de forma involuntária. Pode ser mencionado também a falta de tratamento estatístico para os resultados obtidos, uma vez que existem somente procedimentos para organização dos dados.

\subsubsection{Aplicação da técnica de grupos focais junto aos produtores rurais e profissionais de assistência técnica da Cotrijal}

As sessões de grupos focais ocorreram no início da segunda quinzena do mês de janeiro de 2001, no município de Não-Me-Toque, estado do Rio Grande do Sul, sede da Cotrijal. Foram reunidos dois grupos de produtores rurais associados à Cooperativa e um grupo constituído por membros de seu departamento técnico.

O primeiro grupo de produtores foi constituído por quinze e o segundo por treze participantes, todos agricultores ou pecuaristas da região de abrangência da Cooperativa, ligados ou não ao programa de gerenciamento desenvolvido pela Cotrijal. Não houve um critério pré-definido para a seleção dos participantes. Dentre os associados da Cooperativa, foram convidados e selecionados aqueles produtores que poderiam comparecer na data e horário estipulados. Uma sessão foi realizada pela manhã e outra à tarde, cada uma com cerca de duas horas de duração, sendo destinado um período entre vinte e trinta minutos para preparativos iniciais. A sessão com doze técnicos (engenheiros agrônomos, médicos veterinários e técnicos agrícolas) que prestam assistência aos agropecuaristas, tanto na sede da Cooperativa, como nos entrepostos (filiais) ${ }^{15}$ foi realizada na noite do mesmo dia.

\footnotetext{
${ }^{15}$ Os vinte e dois entrepostos da Cotrijal estão localizados nos municípios de Não-Me-Toque, Almirante Tamandaré, Carazinho, Colorado, Coqueiros do Sul, Ernestina, Lagoa dos Três
} 
No início de cada uma das sessões dos grupos focais o moderador fez uma breve apresentação da equipe que o acompanhava (dois observadores e um responsável pela gravação) e pediu a cada participante do grupo que se apresentasse e citasse qual a principal atividade por ele desenvolvida. Em seguida o moderador fez uma breve explanação sobre a técnica de grupos focais, utilizando-se de exemplos de maior domínio pelo grupo. Na seqüência, o moderador solicitou a opinião individual sobre as características de um produtor rural de sucesso e encorajou o debate entre os participantes. Seguiram-se discussões sobre outras perguntas previamente escolhidas.

Todas as sessões foram gravadas e transcritas posteriormente. A síntese etnográfica foi analisada, buscando-se identificar um padrão para as discussões e idéias apresentadas. De forma geral, os resultados parciais obtidos com os grupos focais confirmam as colocações feitas nas considerações iniciais e na justificativa deste estudo. Parte dos objetivos da pesquisa também foi atingido, principalmente no que concerne a uma identificação preliminar de quais são as características de um bom produtor rural do ponto de vista tanto dos agricultores quanto dos membros da assistência técnica.

\subsection{Estruturação e elaboração dos questionários}

A análise dos resultados obtidos com os grupos focais possibilitou a compreensão do que é considerado pelos agentes (produtores rurais e técnicos que os assistem) como um produtor rural de sucesso. Gerou subsídios para a elaboração de um questionário aplicado em duas etapas junto aos produtores associados à Cotrijal, tendo em vista a necessidade de obtenção de dados que permitissem a análise quantitativa.

Cantos, Nicolau Vergueiro, Saldanha Marinho, Santo Antônio do Planalto, Victor Graeff e XV de Novembro. 
O primeiro dos questionários contou com afirmativas que procuraram dar ênfase às características, relatadas nos grupos focais, que descreviam um bom produtor rural. Com base no modelo teórico proposto, a formulação das afirmações levou em consideração a necessidade de se priorizar assuntos relacionados às funções administrativas que constituem 0 processo administrativo (planejamento, organização, direção e controle) e das características da visão (estratégica e operacional) aplicadas nas diferentes áreas de ação da empresa agropecuária (produção, finanças, comercialização e recursos humanos).

Conformaram-se, assim, trinta e duas afirmativas relacionadas à "matriz de atividades administrativas" do trabalho de Canziani (2001), apresentada na revisão de literatura. A cada atividade administrativa desta matriz foi elaborada uma afirmação. Elas são sintetizadas nos Quadros 3 e 4, e constituídas por 32 locis, correspondentes às 8 linhas e 4 colunas destes quadros. Nas oito linhas estão as quatro funções administrativas (planejamento, organização, direção e controle) subdivididas em dois níveis empresariais (estratégico e operacional). Nas quatro colunas estão representadas as áreas de ação da empresa: produção, finanças, comercialização e recursos humanos. No interior da "matriz 8 x 4", cada uma das 32 afirmativas relaciona-se à uma das interações administrativas possíveis de serem realizadas e que em conjunto formam o chamado processo administrativo. 


\begin{tabular}{|c|c|c|}
\hline $\begin{array}{l}\text { ÁREA ADMINISTRATIVA } \\
\text { FUNCÕES ADMINISTRATIVAS }\end{array}$ & PRODUÇÃO & FINANÇAS \\
\hline $\begin{array}{l}\text { PLANEJAMENTO } \\
\text { ESTRATÉGICO }\end{array}$ & $\begin{array}{l}\text { 4) O bom produtor rural faz } \\
\text { diversificação da produção para } \\
\text { se proteger de frustrações de } \\
\text { safras, de preços baixos e } \\
\text { diminuir as variações de sua } \\
\text { renda. }\end{array}$ & $\begin{array}{l}\text { 17) O bom produtor rural tem } \\
\text { como objetivo principal do } \\
\text { empreendimento rural promover } \\
\text { um bom padrão de vida para } \\
\text { família (como, por exemplo, dar } \\
\text { boa educação para os filhos, ter } \\
\text { um bom plano de saúde e dispor } \\
\text { de conforto dentro de casa). }\end{array}$ \\
\hline $\begin{array}{l}\text { PLANEJAMENTO } \\
\text { OPERACIONAL }\end{array}$ & $\begin{array}{l}\text { 26) O bom produtor rural define } \\
\text { o que vai produzir anualmente } \\
\text { com base nos preços de } \\
\text { mercado. }\end{array}$ & $\begin{array}{l}\text { 1) O bom produtor rural faz } \\
\text { planejamento ou orçamento de } \\
\text { qual a melhor época de comprar } \\
\text { adubo, sementes, defensivos } \\
\text { agrícolas. }\end{array}$ \\
\hline $\begin{array}{l}\text { ORGANIZAÇÃO } \\
\text { ESTRATÉGICA }\end{array}$ & $\begin{array}{l}\text { 5) O bom produtor rural sempre } \\
\text { adota a estratégia de fazer } \\
\text { parceria, associação r ou } \\
\text { condomínios de produção } \\
\text { agropecuária para diminuir os } \\
\text { custos de produção e os riscos } \\
\text { da atividade agrícola. }\end{array}$ & $\begin{array}{l}\text { 31) O bom produtor rural sempre } \\
\text { controla seus gastos e sabe } \\
\text { analisar os dados levantados } \\
\text { (anotados) de modo que torne } \\
\text { possível saber qual foi o lucro } \\
\text { obtido em cada atividade }\end{array}$ \\
\hline $\begin{array}{l}\text { ORGANIZAÇÃO } \\
\text { OPERACIONAL }\end{array}$ & $\begin{array}{l}\text { 10) O bom produtor rural sempre } \\
\text { mantém a lavoura com um bom } \\
\text { aspecto visual, livre de pragas e } \\
\text { doenças e mantém instalações, } \\
\text { máquinas e equipamentos } \\
\text { limpos e bem conservados. }\end{array}$ & $\begin{array}{l}\text { 11) O bom produtor rural sempre } \\
\text { possui um sistema de controle, } \\
\text { mesmo que simplificado, do tipo } \\
\text { entradas e saídas de dinheiro do } \\
\text { caixa. }\end{array}$ \\
\hline $\begin{array}{c}\text { DIREÇÃO } \\
\text { ESTRATÉGICA }\end{array}$ & $\begin{array}{l}\text { 22) O bom produtor rural sempre } \\
\text { adota rapidamente novas } \\
\text { técnicas de produção (é } \\
\text { inovador) e investe em novas } \\
\text { máquinas e equipamentos. }\end{array}$ & $\begin{array}{l}\text { 32) O bom produtor rural sempre } \\
\text { toma atitude diante das } \\
\text { dificuldades financeiras e não } \\
\text { fica esperando passivamente do } \\
\text { governo uma solução para os } \\
\text { seus problemas. }\end{array}$ \\
\hline $\begin{array}{c}\text { DIREÇÃO } \\
\text { OPERACIONAL }\end{array}$ & $\begin{array}{l}\text { 27) O bom produtor rural é } \\
\text { aquele que é copiado pelos } \\
\text { outros, que serve de exemplo na } \\
\text { forma de condução do seu } \\
\text { empreendimento. }\end{array}$ & $\begin{array}{l}\text { 7) O bom produtor rural sempre } \\
\text { vende sua produção de acordo } \\
\text { com a necessidade de caixa } \\
\text { (dinheiro) para pagar os } \\
\text { compromissos financeiros. }\end{array}$ \\
\hline $\begin{array}{l}\text { CONTROLE } \\
\text { ESTRATÉGICO }\end{array}$ & $\begin{array}{l}\text { 8) O bom produtor consegue } \\
\text { produzir com produtividade mais } \\
\text { alta e custos mais baixos que } \\
\text { seus vizinhos. }\end{array}$ & $\begin{array}{l}\text { 30) O bom produtor rural é aquele } \\
\text { que faz anotações dos seus } \\
\text { gastos e obrigações financeiras de } \\
\text { longo prazo. }\end{array}$ \\
\hline $\begin{array}{l}\text { CONTROLE } \\
\text { OPERACIONAL }\end{array}$ & $\begin{array}{l}\text { 9) O bom produtor é aquele que } \\
\text { sabe, efetivamente, se suas } \\
\text { atividades estão dando lucro ou } \\
\text { prejuízo. }\end{array}$ & $\begin{array}{l}\text { 28) O bom produtor rural sempre } \\
\text { tem um controle separado dos } \\
\text { gastos da família e dos gastos } \\
\text { com as atividades da propriedade. }\end{array}$ \\
\hline
\end{tabular}




\begin{tabular}{|c|c|c|}
\hline $\begin{array}{l}\text { ÁREA ADMINISTRATIVA } \\
\text { FUNÇÕES ADMINISTRATIVAS }\end{array}$ & COMERCIALIZAÇÃO & $\begin{array}{l}\text { RECURSOS } \\
\text { HUMANOS }\end{array}$ \\
\hline $\begin{array}{l}\text { PLANEJAMENTO } \\
\text { ESTRATÉGICO }\end{array}$ & $\begin{array}{l}\text { 12) O bom produtor rural é } \\
\text { aquele que deixa para a } \\
\text { cooperativa toda a estratégia de } \\
\text { comercialização de sua } \\
\text { produção. }\end{array}$ & $\begin{array}{l}\text { 14) O bom produtor rural sempre } \\
\text { delega atividades aos filhos com } \\
\text { o objetivo de fazer seu sucessor } \\
\text { e dar continuidade a propriedade } \\
\text { rural no futuro. }\end{array}$ \\
\hline $\begin{array}{l}\text { PLANEJAMENTO } \\
\text { OPERACIONAL }\end{array}$ & $\begin{array}{l}\text { 21) O bom produtor rural é } \\
\text { aquele que vende sua produção } \\
\text { apenas quando precisa de } \\
\text { recursos financeiros. }\end{array}$ & $\begin{array}{l}\text { 16) O bom produtor rural é } \\
\text { aquele que sempre consegue } \\
\text { tirar férias e viajar pelo menos } \\
\text { uma vez por ano. }\end{array}$ \\
\hline $\begin{array}{l}\text { ORGANIZAÇÃO } \\
\text { ESTRATÉGICA }\end{array}$ & $\begin{array}{l}\text { 13) O bom produtor rural } \\
\text { sempre é o responsável pelas } \\
\text { compras e vendas r na } \\
\text { propriedade. Só transações de } \\
\text { pequenos valores podem ser } \\
\text { feitas pelos empregados da } \\
\text { propriedade. }\end{array}$ & $\begin{array}{l}\text { 24) O bom produtor rural sempre } \\
\text { participa de encontros técnicos, } \\
\text { cursos e feiras agropecuárias e } \\
\text { estimula seus empregados e } \\
\text { familiares a participarem de } \\
\text { cursos de capacitação rural. }\end{array}$ \\
\hline $\begin{array}{l}\text { ORGANIZAÇÃO } \\
\text { OPERACIONAL }\end{array}$ & $\begin{array}{l}\text { 23) O bom produtor é aquele } \\
\text { que sabe distinguir a boa da má } \\
\text { informação quanto a preços e } \\
\text { qualidade dos insumos } \\
\text { disponíveis no mercado. }\end{array}$ & $\begin{array}{l}\text { 18) O bom produtor rural deve } \\
\text { estar sempre presente na } \\
\text { propriedade rural, pois assim ele } \\
\text { pode acompanhar e participar de } \\
\text { perto do desenvolvimento dos } \\
\text { trabalhos. }\end{array}$ \\
\hline $\begin{array}{l}\text { DIREÇÃO } \\
\text { ESTRATÉGICA }\end{array}$ & 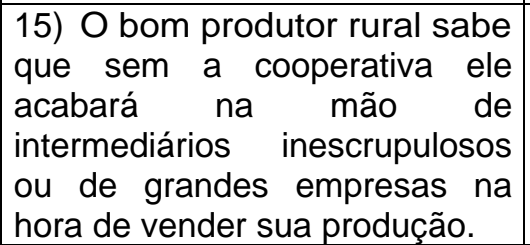 & $\begin{array}{l}\text { 3) O bom produtor rural faz com } \\
\text { que todos os empregados fiquem } \\
\text { sabendo o que foi planejado. } \\
\text { Assim, todos sabem o que têm } \\
\text { que fazer. }\end{array}$ \\
\hline $\begin{array}{l}\text { DIREÇÃO } \\
\text { OPERACIONAL }\end{array}$ & $\begin{array}{l}\text { 2) O bom produtor rural é } \\
\text { aquele que acompanha, } \\
\text { cotidianamente, os preços de } \\
\text { mercado, tanto dos produtos } \\
\text { quanto dos insumos. }\end{array}$ & $\begin{array}{l}\text { 19) O bom produtor rural sempre } \\
\text { passa as ordens de serviços aos } \\
\text { empregados de forma clara e } \\
\text { direta. }\end{array}$ \\
\hline $\begin{array}{l}\text { CONTROLE } \\
\text { ESTRATÉGICO }\end{array}$ & $\begin{array}{l}\text { 25) O bom produtor é aquele } \\
\text { que conhece ou procura } \\
\text { informações sobre os preços } \\
\text { históricos dos produtos (séries } \\
\text { históricas de preços). }\end{array}$ & $\begin{array}{l}\text { 6) O bom produtor rural é aquele } \\
\text { que conhece bem as pessoas } \\
\text { que trabalham em sua } \\
\text { propriedade. }\end{array}$ \\
\hline $\begin{array}{l}\text { CONTROLE } \\
\text { OPERACIONAL }\end{array}$ & $\begin{array}{llr}20) \text { O bom produtor rural } \\
\text { sempre } & \text { procura } & \text { adquirir } \\
\text { insumos a preços } & \text { menores e } \\
\text { compra somente o } & \text { mínimo } \\
\text { necessário. } & & \end{array}$ & $\begin{array}{l}\text { 29) O bom produtor rural sempre } \\
\text { zela pela sua imagem visual. }\end{array}$ \\
\hline
\end{tabular}

Quadro 4 - Afirmativas utilizadas no questionário, agrupadas segundo atividade administrativa (comercialização e recursos humanos).

Fonte: elaboração do autor. 
As questões $04,17,12$ e 14 relacionam-se ao planejamento estratégico das quatro áreas de atuação em uma propriedade rural. A questão 04 ("o bom produtor rural faz diversificação da produção para se proteger de frustrações de safras, de preços baixos e diminuir as variações de sua renda") diz respeito à produção. A questão 17 ("o bom produtor rural tem como objetivo principal do empreendimento rural promover um bom padrão de vida para família (como, por exemplo, dar boa educação para os filhos, ter um bom plano de saúde e dispor de conforto dentro de casa)") relaciona-se às finanças e a 12 ("o bom produtor rural é aquele que deixa para a cooperativa toda a estratégia de comercialização de sua produção") com a comercialização. A afirmativa 14 relaciona-se aos recursos humanos ("o bom produtor rural sempre delega atividades aos filhos com o objetivo de fazer seu sucessor e dar continuidade a propriedade rural no futuro").

O planejamento operacional está refletido nas questões $26,01,21$ e 16, relacionando-se aos aspectos de produção, finanças, comercialização e recursos humanos respectivamente. São elas: (26) "o bom produtor rural define o que vai produzir anualmente com base nos preços de mercado"; (01) "o bom produtor rural faz planejamento ou orçamento de qual a melhor época de comprar adubo, sementes, defensivos agrícolas"; (21) "o bom produtor rural é aquele que vende sua produção apenas quando precisa de recursos financeiros"; e (16) "o bom produtor rural é aquele que sempre consegue tirar férias e viajar pelo menos uma vez por ano".

As afirmações de números 05, 31, 13 e 24, por sua vez, contemplam a organização estratégica. A questão (5) é relacionada com a produção ("o bom produtor rural sempre adota a estratégia de fazer parceria, associação ou condomínios de produção agropecuária para diminuir os custos de produção e os riscos da atividade agrícola"); a (31) com as finanças ("o bom produtor rural sempre controla seus gastos e sabe analisar os dados levantados (anotados) 
de modo que torne possível saber qual foi o lucro obtido em cada atividade"); a (13) com a comercialização ("o bom produtor rural sempre é o responsável pelas compras e vendas na propriedade. Só transações de pequenos valores podem ser feitas pelos empregados da propriedade") e a (24) ("o bom produtor rural sempre participa de encontros técnicos, cursos e feiras agropecuárias e estimula seus empregados e familiares a participarem de cursos de capacitação rural"), vincula-se à gestão de recursos humanos.

A organização operacional é investigada nas questões 10, 11, 23 e 18. São elas: com relação à área produtiva, 10 ("o bom produtor rural sempre mantém a lavoura com um bom aspecto visual, livre de pragas e doenças e mantém instalações, máquinas e equipamentos limpos e bem conservados"); com relação às finanças, 11 ("o bom produtor rural sempre possui um sistema de controle, mesmo que simplificado, do tipo entradas e saídas de dinheiro do caixa”); com relação à comercialização, 23 (“o bom produtor é aquele que sabe distinguir a boa da má informação quanto a preços e qualidade dos insumos disponíveis no mercado"); e com relação aos recursos humanos, 18 ("o bom produtor rural deve estar sempre presente na propriedade rural, pois assim ele pode acompanhar e participar de perto do desenvolvimento dos trabalhos").

Relaciona-se à direção estratégica da produção a afirmativa 22 ("o bom produtor rural sempre adota rapidamente novas técnicas de produção (é inovador) e investe em novas máquinas e equipamentos"). A de número 32 vincula-se às finanças ("o bom produtor rural sempre toma atitude diante das dificuldades financeiras e não fica esperando passivamente do governo uma solução para os seus problemas"). A afirmação 15 diz respeito à direção estratégica da comercialização ("o bom produtor rural sabe que sem a cooperativa ele acabará na mão de intermediários inescrupulosos ou de grandes empresas na hora de vender sua produção"); e a de número 3 diz respeito à gestão de recursos humanos ("o bom produtor rural faz com que 
todos os empregados fiquem sabendo o que foi planejado. Assim, todos sabem o que têm que fazer").

O posicionamento diante da direção operacional é investigado com as afirmativas 27, 07, 02 e 19. Relaciona-se à produção a de número 27 "o bom produtor rural é aquele que é copiado pelos outros, que serve de exemplo na forma de condução do seu empreendimento". A questão número 07 está relacionada às finanças: "o bom produtor rural sempre vende sua produção de acordo com a necessidade de caixa (dinheiro) para pagar os compromissos financeiros". A de número 02 está relacionada à comercialização: "o bom produtor rural é aquele que acompanha, cotidianamente, os preços de mercado, tanto dos produtos quanto dos insumos" Finalmente, a 19 relaciona-se aos recursos humanos: "o bom produtor rural sempre passa as ordens de serviços aos empregados de forma clara e direta".

As afirmações de números 08, 30, 25 e 06 relacionam-se ao controle estratégico. Relaciona-se a área de produção a afirmativa 08 ("o bom produtor consegue produzir com produtividade mais alta e custos mais baixos que seus vizinhos"); com a área financeira a questão 30 ("o bom produtor rural é aquele que faz anotações dos seus gastos e obrigações financeiras de longo prazo"). A questão 25 relaciona-se a comercialização ("o bom produtor é aquele que conhece ou procura informações sobre os preços históricos dos produtos (séries históricas de preços)") e a questão 6 com os recursos humanos ("o bom produtor rural é aquele que conhece bem as pessoas que trabalham em sua propriedade").

Por fim, as afirmações de números 09, 28, 20 e 29 relacionam-se ao controle operacional da produção, das finanças, da comercialização e dos recursos humanos, respectivamente. São elas: (09) "o bom produtor é aquele que sabe, efetivamente, se suas atividades estão dando lucro ou prejuízo"; (28) 
"o bom produtor rural sempre tem um controle separado dos gastos da família e dos gastos com as atividades da propriedade"; (20) "o bom produtor rural sempre procura adquirir insumos a preços menores e compra somente o mínimo necessário" e (29) "o bom produtor rural sempre zela pela sua imagem visual".

Para medir o grau de concordância dos entrevistados sobre as afirmações contidas no questionário, optou-se por uma escala contínua entre zero e dez, uma vez que é considerada como de fácil aplicação pelo produtor rural, tendo em vista seu freqüente uso no sistema educacional brasileiro. ${ }^{16}$ Com tal escala, as notas atribuídas pelos entrevistados possuíam o seguinte significado: nota 0 (zero), total discordância com a afirmação; notas entre 1 (um) e 4 (quatro), discordância parcial; nota 5 (cinco), indiferença com relação à afirmação; notas entre 6 (seis) e 9 (nove), concordância parcial; e nota 10 (dez), total concordância com a afirmação.

A nota atribuída às trinta e duas afirmativas relacionadas à administração da empresa rural tem por objetivo a obtenção da "opinião" pessoal do participante, ou seja, o modo como o produtor rural se expressa e pensa sobre cada afirmação, assim como sua "percepção" sobre o assunto, ou seja, o modo como ele a compreende. Assim, cada uma das questões pretende obter as duas noções (opinião e percepção) simultaneamente através do estabelecimento de notas utilizando-se afirmações impessoais ou indiretas. A íntegra deste questionário pode ser visualizada no Apêndice 1.

Foi garantido o sigilo das informações prestadas pelos entrevistados, entretanto a identificação destes foi fundamental para a elaboração do segundo

\footnotetext{
${ }^{16}$ Uma das alternativas para resposta ao questionário compreendia a escala "tipo Likert", que foi preterida pela escala contínua de notas entre zero e dez. A escala "tipo Likert" compreende respostas do tipo "concordo plenamente", "concordo parcialmente", "não concordo e nem discordo", "discordo parcialmente", "discordo totalmente". Concluiu-se que este tipo de questionário dificulta 0 entendimento por parte do agricultor brasileiro acostumado, culturalmente, à escala de zero a dez.
} 
questionário. Nesta etapa, os participantes que responderam ao questionário inicial foram listados em ordem alfabética. Esta listagem foi apresentada a outros produtores rurais, associados à Cotrijal e aos membros da assistência técnica. Estes deveriam atribuir notas entre zero e dez para a capacidade administrativa dos produtores inicialmente entrevistados. Diante das notas obtidas, buscava-se verificar a existência de diferenças na percepção da administração da empresa rural por parte de produtores, conforme a classificação dos pares e dos técnicos.

\subsubsection{Aplicação dos questionários junto aos produtores rurais e profissionais da assistência técnica da Cotrijal}

O primeiro questionário foi aplicado junto a uma amostra de cento e quarenta produtores rurais associados à Cotrijal ${ }^{17}$, envolvendo ou não aqueles que já haviam participado do grupo focal. As entrevistas foram realizadas em outubro de 2001, contando inclusive com o apoio dos técnicos que assistem aos entrepostos da Cooperativa. Além da atribuição de notas às trinta e duas afirmativas que enfocavam a opinião do entrevistado a respeito das atividades administrativas, foram solicitadas respostas às seguintes questões: (a) nome do produtor rural; (b) exploração agropecuária mais importante em termos de receita financeira; (c) idade; e (d) quantos anos freqüentou a escola.

Em outras cinco questões apresentadas aos produtores, eles deveriam atribuir nota entre zero e dez para: (a) si próprio, como produtor rural; (b) satisfação pessoal com a atividade agrícola; (c) situação atual da agricultura; (d) preocupação pessoal com a preservação do meio ambiente; (e) preocupação com a qualidade da própria produção (grãos, leite, carne, etc.). Uma outra questão foi feita especificamente a respeito do controle financeiro que é realizado na propriedade rural. Sendo uma questão de múltipla escolha, as 
alternativas compreendiam: (a) participação no programa de gerenciamento desenvolvido pela Cotrijal; (b) realização de anotações detalhadas dos custos da propriedade rural pelo próprio produtor; (c) anotação dos principais custos com a atividade agropecuária; e (d) produtor rural não realiza nenhum tipo de anotação para o controle de gastos da propriedade rural (ou de outra forma, "sabe tudo de cabeça").

Além destas afirmativas, uma outra questão foi incluída no questionário. Solicitava-se notas à capacidade administrativa de alguns produtores rurais também associados à Cotrijal, conhecidos do entrevistado: "dentre os produtores rurais que você conhece (vizinhos e conhecidos), dê uma nota entre 0 (zero) e 10 (dez) para a capacidade de administrar uma propriedade rural". A resposta a esta questão não foi satisfatória. ${ }^{18}$ Assim, tornou-se necessária a adoção de outra estratégia, ou seja, a elaboração de um segundo questionário, contendo a listagem dos cento e quarenta produtores rurais entrevistados na primeira fase. Este segundo questionário foi respondido por 46 produtores rurais e 27 membros da equipe técnica da Cotrijal, envolvendo tanto aqueles que prestam assistência na matriz na cidade de Não-Me-Toque (RS) como nos entrepostos. Assim, procurou-se obter no mínimo três notas (duas de produtores conhecidos e uma dos técnicos) para cada um dos 140 cooperados listados. Ressalte-se que os entrevistados nesta segunda fase não necessariamente estiveram envolvidos nos grupos focais e na primeira rodada de entrevistas.

\footnotetext{
${ }^{17} \mathrm{O}$ número de entrevistados corresponde a $4,6 \%$ dos produtores rurais associados à Cotrijal.

${ }^{18} \mathrm{Um}$ dos motivos que podem ser citados diz respeito à relutância dos entrevistados em atribuir notas aos conhecidos e vizinhos. Muito embora as entrevistas tenham sido realizadas em local isolado e tenha-se garantido sigilo nas informações prestadas, os entrevistados sentiam-se constrangidos principalmente em atribuir notas baixas. Além disto, somente $20 \%$ dos 140 entrevistados foram citados espontaneamente pelos demais.
} 


\subsection{Análise Fatorial}

A "análise fatorial"19 é um processo de análise estatística multivariada, destinada à redução e à sumarização de dados. Pode ser considerada, de forma resumida, como sendo um método de transformação de variáveis originais (em geral correlacionadas entre si) em um conjunto menor de variáveis não correlacionadas, que são combinações lineares das variáveis originais e denominadas "fatores".

A utilização da análise fatorial possibilita o entendimento claro das variáveis que atuam em conjunto e quais as variáveis que mais contribuem para a explicação da variância nos dados originais. Assim, fornece a base de criação de novo conjunto de variáveis que incorpora as características das originais, mas em um número reduzido. Desta maneira, problemas associados a um grande número de indicadores ou alto grau de correlações entre eles podem ser substancialmente reduzidos pela substituição por um número menor de fatores.

O modelo de análise fatorial traz como pressuposto a hipótese de que existem relações lineares entre as variáveis originais e também existe correlação entre elas (correlações diferentes de zero). A partir deste conjunto inicial de variáveis é possível obter um conjunto de fatores com as seguintes características: (a) os fatores são não-correlacionados, ou seja, em termos geométricos são ortogonais entre si; (b) não existe fator que possa ser obtido da combinação linear de quaisquer outros fatores; (c) admite-se que existam menos fatores relevantes para a análise do que variáveis originais.

Malhotra (2001) considera que a análise fatorial assemelha-se à análise de regressão múltipla, uma vez que cada variável pode ser considerada como

\footnotetext{
${ }^{19}$ Mais detalhes a respeito do método de análise fatorial podem ser vistos em Andrade (1989), Hair et al. (1998), Hoffmann (1999), Malhotra (2001) e Sharma (1996).
} 
uma combinação linear dos diferentes fatores. O total de variância de qualquer indicador pode ser decomposto em: (a) parcela que é comum a todos os indicadores, considerada como comunalidade (communality) e (b) parcela específica a cada indicador, chamada de erro de variância ou especificidade (uniqueness) da variável. O modelo de análise fatorial é discutido com profundidade na bibliografia citada, mas será resumido neste trabalho conforme Hoffmann (1999) e Malhotra (2001)

Considerando-se que variáveis são padronizadas, observa-se que o modelo é constituído por $n$ equações, cada uma representando uma das variáveis, constituída por $m$ fatores comuns (com $m<n$ ) e de um fator específico. Para a i-ésima variável tem-se:

$x_{i j}=a_{i 1} f_{1 j}+a_{i 2} f_{2 j}+\ldots+a_{i n} f_{m j}+u_{i} y_{i j}$

ou

$x_{i j}=\sum_{p=1}^{m} a_{i p} f_{p j}+u_{i} y_{i j}$

onde

$f_{p j}$ representa o valor do $p$-ésimo fator comum para a j-ésima observação, ou seja, o valor dos fatores comuns;

$a_{i p}(\operatorname{com} p=1, \ldots, m)$ e $u_{i}$ são coeficientes; e

$y_{i}$ representa o valor do $i$-ésimo fator específico para a $j$-ésima observação.

Em termos matriciais, o modelo de análise fatorial pode ser escrito como:

$\mathbf{X}=\mathbf{A F}+\mathbf{U Y}$,

onde:

$\mathbf{X}=\left[\begin{array}{cccc}x_{11} & x_{12} & \cdots & x_{1 L} \\ x_{21} & x_{22} & \cdots & x_{2 L} \\ \cdots & \cdots & \cdots & \cdots \\ x_{n 1} & x_{n 2} & \cdots & x_{n L}\end{array}\right], \mathbf{F}=\left[\begin{array}{cccc}f_{11} & f_{12} & \cdots & f_{1 L} \\ f_{21} & f_{22} & \cdots & f_{2 L} \\ \cdots & \cdots & \cdots & \cdots \\ f_{n 1} & f_{n 2} & \cdots & f_{n L}\end{array}\right], \mathbf{Y}=\left[\begin{array}{cccc}y_{11} & y_{12} & \cdots & y_{1 L} \\ y_{21} & y_{22} & \cdots & y_{2 L} \\ \cdots & \cdots & \cdots & \cdots \\ y_{n 1} & y_{n 2} & \cdots & y_{n L}\end{array}\right]$, 


$$
\mathbf{A}=\left[\begin{array}{cccc}
a_{11} & a_{12} & \cdots & a_{1 L} \\
a_{21} & a_{22} & \cdots & a_{2 L} \\
\cdots & \cdots & \cdots & \cdots \\
a_{n 1} & a_{n 2} & \cdots & a_{n L}
\end{array}\right], \mathrm{e} \mathbf{U}=\left[\begin{array}{cccc}
u_{1} & 0 & \cdots & 0 \\
0 & u_{2} & \cdots & 0 \\
\cdots & \cdots & \cdots & \cdots \\
0 & 0 & \cdots & u_{n}
\end{array}\right]
$$

Conforme já mencionado, uma das hipóteses do modelo é a inexistência de correlação (ortogonalidade) entre os fatores específicos $\left(y_{i}, \operatorname{com} i=1, \ldots, n\right) \mathrm{e}$ destes com os $m$ fatores comuns $\left(f_{p}\right.$, com $\left.p=1, \ldots, m\right)$. Tem-se também que os fatores comuns são ortogonais entre si. Além disto, cada fator passa a ser considerado como uma nova variável aleatória com média zero e os respectivos vetores, no espaço $L$-dimensional, tem módulo igual a 1, isto é:

$$
\sum_{j} f_{p j}=\sum_{j} y_{i j}=0
$$

e

$$
\sum_{j} f_{p j}^{2}=\sum_{j} y_{i j}^{2}=1
$$

para $p=1, \ldots, m$ e $i=1, \ldots, n$.

Assim, é possível definir que:

$\mathbf{Y Y}^{\prime}=\mathbf{I}_{\mathbf{n}}$, (matriz unitária de ordem $n$ ), e

$\mathbf{F F}^{\prime}=\mathbf{I}_{\mathbf{m}}($ matriz unitária de ordem $m)$.

Sendo os $m$ fatores comuns e os $n$ fatores específicos ortogonais entre si é possível concluir que $\mathbf{F Y}^{\prime}=\mathbf{0}$, sendo esta uma matriz nula de ordem $m \times n$. Define-se $\mathbf{R}$ como a matriz de correlações simples existente entre os indicadores, ou seja, $\mathbf{R}=\mathbf{X X}$ '.

O modelo de análise fatorial reduz-se a:

$\mathbf{R}=\mathbf{X X}^{\prime}$

sendo $\mathbf{X}=\mathbf{A F}+\mathbf{U Y}$, tem-se que

$\mathbf{R}=\mathbf{X X}=(\mathbf{A F}+\mathbf{U Y})\left(\mathbf{F}^{\prime} \mathbf{A}^{\prime}+\mathbf{Y}^{\prime} \mathbf{U}^{\prime}\right)$ 
$R=A F F A^{\prime}+A F Y^{\prime} U^{\prime}+$ UYF'A' + UYY'U'

$\mathbf{R}=\mathbf{X X ^ { \prime }}=\mathbf{A A ^ { \prime }}+\mathbf{U}^{2}$.

Cada elemento da diagonal de $\mathbf{R}$ é igual à unidade. Assim, tem-se:

$1=\sum_{j=1}^{L} x_{i j}^{2}=\sum_{p=1}^{m} a_{i p}^{2}+u_{i}^{2}$.

ou seja, a correlação existente entre os indicadores pode ser decomposto em fatores comuns e específicos. A parcela referente à especificidade (uniqueness) é dada pelo último termo desta expressão. A comunalidade (communality) existente entre os indicadores é destacada pelo primeiro termo da última expressão, sintetizado como:

$h_{i}^{2}=\sum a_{i p}^{2}$.

Assim, $h_{i}^{2}+u_{i}^{2}=1$.

Considerando-se um elemento da matriz $\mathbf{R}$ fora da diagonal principal, obtém-se:

$r\left(x_{1}, x_{k}\right)=\sum a_{i p} a_{k p}$.

ou seja, as correlações entre as variáveis $x_{i}$ podem ser obtidas a partir da matrizA.

Ao multiplicar os dois membros desta expressão por $f_{p j}$, realizando o somatório com relação a $j$ obtém-se:

$r\left(x_{i}, f_{p}\right)=a_{i p}$,

lembrando que os fatores comuns $\left(f_{n}\right)$ e os fatores específicos $\left(y_{i}\right)$ são vetores ortogonais entre si, com módulo igual a 1. 
Em termos matriciais tem-se:

$\mathbf{X} \mathbf{F}^{\prime}=\mathbf{A}$,

onde a i-ésima linha da matriz $\mathbf{A}$ é constituída pelos coeficientes de correlação da $i$-ésima variável com cada um dos $m$ fatores comuns. Essa matriz é chamada de matriz de estrutura dos fatores ou matriz de estrutura. Denominase de cargas fatoriais (factor loading) os coeficientes $a_{i p}$, uma vez que sendo fatores ortogonais, estes coincidem com os elementos da matriz de estrutura. 


\section{RESULTADOS E discusSÃo}

Neste capítulo são apresentados e discutidos os resultados obtidos nas análises qualitativa e quantitativa. Inicialmente são apresentadas as características de um bom produtor rural, obtidas por meio de entrevistas coletivas, utilizando-se a técnica de grupos focais. Procurou-se, dentre as idéias discutidas, identificar aquelas que se relacionam aos aspectos mencionados teoricamente em termos de competência gerencial e atividades administrativas. Também é dado destaque às características que corroboram as idéias teóricas que vinculam um produtor bem sucedido àquele que mantém o equilíbrio entre os aspectos pessoais e profissionais.

Apresentam-se, na seqüência, os resultados obtidos com a aplicação dos questionários, buscando descrever em termos quantitativos as características de um produtor rural de sucesso. É feita uma breve descrição da amostra de produtores rurais entrevistados e apresentada uma análise estatística das notas atribuídas a cada atividade administrativa. Em seguida é descrito o conjunto de fatores que melhor sintetiza a variabilidade das notas atribuídas pelos agricultores entrevistados às 32 questões dos Quadros 3 e 4 . Por fim são apresentadas as regressões que correlacionam (explicam) as três notas atribuídas à qualidade administrativa dos agricultores (auto-avaliação, dos pares e dos técnicos) como função dos fatores identificados e das variáveis adicionais consideradas. 


\subsection{Resultados obtidos com a aplicação dos grupos focais}

Os resultados obtidos com a aplicação do método de grupos focais junto a produtores e membros da equipe técnica da Cooperativa Tritícola Mista Alto Jacuí Ltda. (Cotrijal) apontaram para a existência de diversas características administrativas que podem ser atribuídas a um bom produtor rural. Assim, por meio da análise das transcrições das três sessões realizadas constatou-se que é opinião praticamente unânime entre os participantes que deve haver um equilíbrio entre as características profissionais e pessoais dos bons produtores rurais. Ou seja, um produtor de sucesso não somente é um bom profissional; ele também precisa ser, reconhecidamente, uma boa pessoa.

No que diz respeito aos aspectos profissionais, foi dado destaque à competência do produtor para o desenvolvimento da atividade agropecuária. Esta deve ser compreendida não somente pelo conhecimento técnico e produtivo das atividades a serem desempenhadas, como também por um conjunto mais amplo de qualificações, envolvendo aptidões, habilidades e atitudes, que proporciona ao produtor rural capacitação para a tomada de decisões. Alguns dos participantes dos grupos focais mencionaram que um produtor rural de sucesso "é aquele que consegue maior produtividade e rentabilidade", ou seja é "... aquele que planta bem e colhe bem"; sendo "... um bom produtor em todas as áreas, gado de corte, leite, grãos ...". Além dos aspectos produtivos, foram destacados que um bom produtor deve "conhecer a própria propriedade onde ele está produzindo"; "planejar um pouco, ... é importante ouvir o técnico mas não ficar esperando a receita pronta"; "poder se dedicar àquilo que faz"; "buscar solução para os problemas, independentemente do tamanho ou atividade"; "saber economizar, saber fazer, saber trabalhar e dos recursos que tem, fazer um negócio rentável”. 
Em complemento a estas considerações, foi mencionado durante as sessões que é igualmente importante para a caracterização de um bom produtor rural o desejo de ampliar a competência, por meio da busca de conhecimento necessário ao desenvolvimento de suas atividades. Desta forma, um produtor receptivo, que procura informações técnicas e econômicas a respeito dos aspectos produtivos, comerciais, financeiros e de recursos humanos de sua atividade foi geralmente vinculado ao sucesso. Com relação a isto, o contato com técnicos (engenheiros agrônomos, médicos veterinários, técnicos agrícolas, zootecnistas, administradores de empresas e economistas) foi considerado importante pelos participantes dos grupos focais: "com as mudanças que estão ocorrendo hoje em dia é difícil o agricultor acompanhar (...), podemos (...) buscar informações e nos assessorarmos"; "o produtor de sucesso ouve a equipe técnica para a escolha dos insumos e de como deve conduzir a lavoura"; "quando queremos alguma coisa, chamamos os técnicos, porque eles têm mais experiência do que ocorre em outros lugares, sabem se deu certo ou não”; “... a informação é fundamental, tanto na área técnica como na área de mercado"; "em dúvida sobre comercialização, devemos procurar a opinião de um especialista do ramo". Além da consulta aos técnicos, importante também seria a atitude diante das informações: um produtor bem sucedido deve "receber (as informações) e colocá-las em prática, senão não adianta a presença e os conselhos dos técnicos".

O acesso a qualquer tipo de informação que facilite a tomada de decisão também deve fazer parte da rotina de um produtor rural bem sucedido, sendo dado destaque à troca de experiências junto a vizinhos ou conhecidos. Com isto, foram mencionados que "o sucesso é conseguir juntar o maior número de informações a respeito da sua atividade e em cima disso tentar se planejar..."; "muitas vezes o agricultor fica no campo e deixa de buscar informações sobre o mercado e outras oportunidades"; o bom produtor “... acompanha as mudanças 
na política do governo"; "procura os órgãos públicos e a cooperativa para auxiliar no desenvolvimento de investimentos".

A busca de informações por meio da participação em eventos ou cursos que ampliam a qualificação do produtor foi mencionada como elemento importante relacionado ao produtor de sucesso: "o bom agricultor tem que adquirir conhecimento participando de cursos, encontros..."; "além dos cursos de capacitação rural ele deve aprender um pouco sobre administração de empresas".

Além da troca de experiências com os demais produtores, alguns dos participantes dos grupos focais relacionaram o compartilhamento de risco por meio da realização de parcerias, associações ou condomínios de exploração agropecuária como uma das características de um empreendimento rural de sucesso. Podem ser citados alguns depoimentos que traduzem as vantagens decorrentes da adoção desta estratégia: ter sucesso significa "fazer parceria com os vizinhos para economizar na aquisição de máquinas"; "é importante a parceria entre a família e vizinhos"; "com a parceria dos agricultores com a cooperativa, com associações, é possível diminuir os custos e obter melhores resultados"; "a associação possibilita que vários produtores se juntem e comprem uma máquina para fazer o serviço para vários agricultores"; "acho que a união faz a força, mas esta união não deve ser muito grande, tem que limitar o número de pessoas, criar mais grupos com menos pessoas".

Os benefícios da estratégia de parceria ou associação entre os produtores, entretanto, não pareceu ser consensual entre os participantes. Alguns destacaram experiências mal sucedidas ou enfatizaram a necessidade de realização somente com familiares: "nós tínhamos um círculo de máquinas, semelhante ao que existe na Europa; funcionou até um certo ponto (...) acabou não vingando. Ainda existe uma grande dificuldade para mudar nossa 
mentalidade para trabalharmos em conjunto"; "a parceria e a associação dependem do entendimento entre os produtores (...). Tendo as máquinas eu posso plantar e colher na hora que eu quero sem entrar num escalonamento ou rodízio"; "a formação destas associações vai depender do nivelamento dos produtores (...) em quantidade de área, financeira e de cabeça também. A pessoa tem que estar preparada para assumir o ingresso numa associação senão não dá certo"; "o associativismo é muito bom entre produtores que sabem como ele funciona"; "eu sou mais favorável ao uso de máquinas e equipamentos entre parentes próximos, trocar ajuda e serviços (...) porque é muito difícil administrar a cabeça das pessoas"; deve-se "manter a união entre a família para não aumentar os custos com máquinas e não diminuir o tamanho da propriedade".

A diversificação da produção também foi citada como estratégia para diminuição de risco. Alguns participantes dos grupos focais mencionaram que "o agricultor de sucesso tem que diversificar: produzir leite, aves, lavoura". Outros depoimentos são: "devemos partir para uma diversificação na produção"; "você tem que fazer uma diversificação para se proteger das frustrações ou revés de safras".

Tanto os produtores como os técnicos que estiveram presentes nos grupos focais destacaram a importância da adoção de novas idéias, tecnologias ou sistemas de produção. Ou seja, um produtor inovador é vinculado a um produtor bem sucedido. Para tanto, o produtor deve "tentar novas tecnologias (...) se manter bem informado, acreditar na pesquisa", utilizar "insumos modernos"; ter "as melhores máquinas da região" ou conseguir "trocar de máquinas todos os anos", posicionando-se "sempre mais à frente" em termos tecnológicos. 
A organização da produção agropecuária e da propriedade rural também foi destacada como um fator que caracteriza um produtor rural de sucesso. Alguns depoimentos confirmam esta colocação: um bom agricultor "tem que ser organizado, não adianta conduzir mal as atividades da lavoura"; "deve manter um plano de atividades". Destaque foi dado à organização pessoal do agricultor e da propriedade, em termos de aspectos visuais. Vinculou-se um produtor de sucesso àquele que tem "lavoura melhor, livre de pragas e plantas daninhas, bem conduzida"; "a propriedade organizada, galpão bem pintado, cerca bem feita, barranco limpo e roçado"; "casa pintada, carro bom", "bom asseio pessoal, higiene"; "vida pessoal bem organizada (...) que investe na melhoria da propriedade"; "higiene bem feita, melhor apessoado, livre de bebida, bem vestido ...". Note-se que estas características não foram consensuais a todos os participantes. Alguns tinham a opinião que a organização aparente da propriedade e da produção, ou seja, aquela que pode ser visualmente percebida pelos demais não era importante. "Muitas vezes ter a granja limpa, ter as melhores máquinas e bom aspecto visual da propriedade não quer dizer nada. Se olharmos o lado administrativo vamos ver que ele está cheio de dívidas. Então, os próprios agricultores pecam usando este efeito visual".

O controle financeiro dos custos de produção e dos gastos com a família e com a manutenção das atividades, também foi destacado como uma das principais características de produtores rurais de sucesso. Assim, "o bom produtor sabe o que deve e o quanto tem que pagar"; " ... nunca investe além do que seu patrimônio pode pagar", "consegue modernizar a propriedade sem estar devendo". O controle dos gastos permitem ao produtor a obtenção de "números que nos mostram se há lucro ou não"; "saber o quanto que sobra. Quando se tem o custo de produção você sabe se o lucro obtido é bom ou ruim". 
Coube destaque também às atividades de planejamento da produção e das atividades a serem desempenhadas tanto pelo proprietário, como pelos empregados e familiares envolvidos com a produção. O planejamento foi mencionado como importante para a divulgação tanto das atividades rotineiras junto a todos os envolvidos, como também para esclarecimentos quanto às diretrizes futuras da propriedade. Tais considerações ficaram evidentes pelos depoimentos prestados: para ser um bom produtor é necessário "planejar um pouco"; "visão ampla e um planejamento estratégico do futuro"; "saber programar os passos"; "produzir o máximo na propriedade, visando um baixo custo"; "ter uma boa visão do mercado para fazer as vendas na hora certa ...". A importância do planejamento foi sintetizada por um dos participantes: "o planejamento da lavoura é importante para plantar bem, para sair uma planta boa, para colher bem. Se os preços forem bons, melhor ainda; senão, uma boa safra ajuda a diminuir os prejuízos".

Além da menção às características diretamente vinculadas à produção e à comercialização, os participantes dos grupos focais deram ênfase a aspectos relacionados ao lado pessoal ou familiar de um bom produtor rural. Trata-se de uma extrapolação à noção tradicional de indivíduo maximizador de lucros, incorporando alguns elementos subjetivos tais como a liberdade e autonomia decisória; tirar férias, fazer o próprio horário, realizar um passeio com a família também têm muito valor para os participantes. Isto pode ser comprovado pelos seguintes depoimentos: bom produtor "é aquele produtor que ganha pelo menos para fazer uma viagem por ano"; que "tem direito de gozar 5-10 dias" ou “... um mês de férias ..."; que "viaja a passeio"; "é aquele que usufrui do lazer dentro das possibilidades dele, não é escravo dele mesmo"; ou que "dá lazer à sua família".

Cabe ressaltar a importância e o papel da família na condução das atividades administrativas. Alguns participantes vincularam um bom produtor 
àquele que envolve a família diretamente com a propriedade rural. Neste caso, um produtor de sucesso é capaz de absorver ou envolver a mão-de-obra familiar na atividade produtiva dentro da propriedade ou envolvê-la com aspectos relacionados ao planejamento ou gerenciamento dos negócios fora da propriedade. Alguns depoimentos que confirmam este pensamento podem ser citados, dentre eles: "um bom agricultor deve (...) levar ao conhecimento dos filhos e da esposa o que faz e o que pretende fazer a curto e médio prazo"; é aquele que deve ir "passando para a família as atividades do dia-a-dia, os custos", de modo a "poder dar seguimento aos filhos, assim como obteve dos pais". Destacam também "se a esposa e os filhos participam (da atividade produtiva) eles dão valor e dividem as responsabilidades, e sentem-se valorizados podendo partilhar das responsabilidades ...".

Ainda no que diz respeito à família, alguns outros participantes foram mais generalistas, mencionando simplesmente que um bom produtor é capaz de promover um bom padrão de vida aos familiares, sem necessidade de envolvimento com a atividade agropecuária. Consideram, pois, que o bom produtor rural "é aquele que consegue expandir o seu patrimônio, dá lazer a sua família ..."; que "vive bem com a família, com os pais, irmãos". Além de conforto em termos materiais, foi latente a possibilidade de dar educação formal aos filhos: um bom produtor rural "tem a preocupação de ensinar e dar escolaridade para os filhos até a faculdade", que "pode pagar uma faculdade para os filhos"; "que está bem na propriedade, que pode (...) educar os filhos, dar escola para eles tirando os recursos da propriedade e da sua atividade, como agricultura, leite, pecuária".

O envolvimento do produtor rural de sucesso com os assuntos comunitários e o reconhecimento social daí derivado também foram mencionados. Para os participantes dos grupos focais o produtor rural de sucesso "vive bem com a família e com a comunidade, tem o respeito da 
comunidade"; é "reconhecido e respeitado pela sociedade (e por isto tem) crédito no comércio"; é aquele "que além da sua propriedade participa de todas as coisas que se referem a sua comunidade"; "é aquele que vai na festa, vai na missa com a família, participa quando morre alguém, vai com a família no enterro"; que é "participativo na cooperativa". Neste sentido alguns participantes chegam a mencionar exemplos de produtores que "profissionalmente são excelentes, mas não são bons vizinhos porque não tiram o tempo para conversar e tomar chimarrão. No aspecto social a nota da pessoa é zero. Outras pessoas são muito queridas e muito prestativas na comunidade".

Além do reconhecimento da sociedade, um bom produtor rural deveria servir de exemplo aos demais, pautando as decisões destes. Assim, um produtor que é consultado, admirado ou copiado pelos demais em algumas de suas atitudes poderia ser considerado como bem sucedido: "é aquele produtor focal, que todos olham em direção a ele, se espelham nele"; que "exerce influência na região, é um líder", ou seja "se os outros produtores seguirem o que eu estou fazendo eu sou um bom produtor rural".

Outro fator subjetivo que caracterizaria o sucesso dos produtores diz respeito à vocação para exercer a atividade agropecuária ou para o trabalho com a terra. Das discussões realizadas pode-se depreender que um produtor bem sucedido "em primeiro lugar tem que ter vocação". Deve igualmente "gostar daquilo que faz. Só se é feliz fazendo aquilo que se gosta"; " se sentir bem naquilo que faz"; "estar realizado com o que está fazendo" e assumir "a agricultura como profissão". Além de vocação, foram mencionadas atitudes pessoais como "é um produtor determinado na sua atividade e não é saudosista"; "é profissional, tem os pés no chão, não depende do governo"; "são pessoas otimistas e que tem vontade de conquistar alguma coisa na vida, buscar o seu espaço e seguir os seus ideais". 
A preservação do meio ambiente revelou-se uma preocupação dos produtores e um dos elementos que faz parte do sucesso empresarial. Isto porque demonstrando respeito para com a natureza, indiretamente o produtor estaria demonstrando respeito para com a sociedade. Assim sendo, um bom produtor "tem a responsabilidade de cuidar daquilo que ganhou dos pais e deixar em condições para os filhos e netos darem continuidade"; e busca "preservar o meio ambiente para que as futuras gerações dêem continuidade a este trabalho"; e "agredir o mínimo possível o meio ambiente". Questionam: "como que ele vai deitar e dormir, destruindo o que é dos filhos e dos netos?".

\subsection{Análise dos questionários}

A aplicação dos questionários foi feita em duas etapas. Na primeira, foram realizadas entrevistas individuais com cento e quarenta produtores rurais associados à Cooperativa Tritícola Mista Alto Jacuí Ltda. (Cotrijal), com o objetivo de quantificar a opinião e a percepção a respeito da capacidade administrativa do produtor rural.

\subsubsection{Caracterização da amostra de produtores entrevistados}

Neste item são sintetizadas as respostas obtidas por meio da aplicação dos questionários e realizadas análises estatísticas preliminares ${ }^{20}$, com base em algumas medidas de tendência central (média e mediana, que demonstram os valores em torno dos quais se agrupam as observações originais). ${ }^{21}$ Do total de cento e quarenta produtores entrevistados, 127 (90,71\% do total) mencionaram que sua exploração agropecuária mais importante em termos de receita financeira é a soja, 2 indicaram milho $(1,43 \%)$ e 9, leite $(6,43 \%)$. Um dos

${ }^{20}$ O software SPSS (Statistical Package for the Social Sciences) foi utilizado para a obtenção dos resultados comentados neste capítulo.

${ }_{21}$ Descrição mais detalhada a respeito das medidas de tendência central não é realizada neste trabalho, devido ao amplo conhecimento público sobre o assunto. 
produtores destacou a piscicultura e outro a pecuária de corte, representando cada um deles $0,71 \%$ do total de entrevistados.

Os dados referentes à idade dos produtores entrevistados estão sintetizados na Tabela 1, sendo a média de idade de 43,2 anos, variando entre o mínimo de 18 e o máximo de 77 anos. Comparando o percentual de freqüência dos dados pesquisados e comparando-os com os dados da Associação Brasileira de Marketing Rural - ABMR (2000) ${ }^{22}$, citado por Canziani (2001), pode-se perceber que o perfil dos produtores rurais entrevistados, associados à Cotrijal, assemelha-se ao perfil dos produtores rurais da região centro-sul do país.

Tabela 1. Idade dos produtores rurais entrevistados - comparativo com dados da ABMR.

\begin{tabular}{lccc}
\hline & \multicolumn{2}{c}{ Cotrijal } & Dados ABMR \\
\cline { 2 - 4 } Idade & Freq. Absoluta & Percentual & Percentual \\
\hline Até 20 anos & 1 & 0,7 & 1,0 \\
De 21 a 30 anos & 21 & 15,0 & 12,0 \\
De 31 a 40 anos & 41 & 29,3 & 27,0 \\
De 41 a 50 anos & 37 & 26,4 & 26,0 \\
Mais que 50 anos & 40 & 28,6 & 34,0 \\
$\quad$ De 51 a 60 anos & 29 & 20,7 & n.d. \\
$\quad$ Mais que 61 anos & 11 & 7,9 & n.d. \\
Total & 140 & 100,0 & 100,0 \\
\hline
\end{tabular}

Fonte: resultados da pesquisa e ABMR (2000), citado por Canziani (2001).

Existe similaridade também quando considera-se a escolaridade ${ }^{23}$ dos produtores entrevistados, conforme Tabela 2. Comparativamente aos dados da ABMR, percebe-se que a principal disparidade diz respeito ao primeiro nível

\footnotetext{
22 ABMR - Associação Brasileira de Marketing Rural. Perfil do consumidor de insumos agropecuários, 1991/92 - 1998/99. São Paulo: s.ed., 2000. 21 p.

${ }^{23}$ Muito embora a nomenclatura para os níveis educacionais brasileiros tenha se alterado (primário e ginásio por ensino fundamental e colegial por ensino médio), preferiu-se manter a denominação utilizada no trabalho da ABMR (2000) de modo a permitir a comparação com os valores obtidos.
} 
educacional. Nesta pesquisa, dentre os $17 \%$ de produtores que cursaram o primário e não o completaram, também estão incluídos os analfabetos. No que diz respeito aos produtores associados à Cotrijal que foram entrevistados, nenhum declarou-se analfabeto e somente 2,1\% (3 produtores) não finalizaram o primário. Quando compara-se o nível médio completo e superior incompleto, os associados à Cotrijal apresentam vantagem com relação à média de produtores da região centro-sul brasileira: $31,4 \%$ contra somente $19 \%$. Em que pese este fato, em termos de ensino superior completo, os produtores entrevistados apresentam pequena desvantagem quando comparados ao estudo da ABMR.

Tabela 2. Escolaridade dos produtores rurais entrevistados - comparativo com dados da ABMR.

\begin{tabular}{|c|c|c|c|}
\hline \multirow[b]{2}{*}{ Escolaridade } & \multicolumn{2}{|c|}{ Cotrijal } & ABMR \\
\hline & Freq. Absol. & Percentual & Percentual \\
\hline $\begin{array}{l}\text { Primário incompleto (até } 3 \text { anos de } \\
\text { estudo) }\end{array}$ & 3 & 2,1 & 17,0 \\
\hline $\begin{array}{l}\text { Primário completo e ginásio } \\
\text { incompleto (até } 7 \text { anos de estudo) }\end{array}$ & 65 & 46,4 & 38,0 \\
\hline $\begin{array}{l}\text { Ginásio completo e colegial incompleto } \\
\text { (até } 10 \text { anos de estudo) }\end{array}$ & 15 & 10,7 & 14,0 \\
\hline $\begin{array}{l}\text { Colegial completo e curso superior } \\
\text { incompleto (até } 14 \text { anos de estudo) }\end{array}$ & 44 & 31,4 & 19,0 \\
\hline Superior completo & 13 & 9,3 & 13,0 \\
\hline Total & 140 & 100,00 & 100,0 \\
\hline
\end{tabular}

Fonte: resultados da pesquisa e ABMR (2000), citado por Canziani (2001).

A Tabela 3 sintetiza os resultados das cinco questões que foram feitas, solicitando ao produtor rural a atribuição de notas entre zero e dez para: (1) si próprio como produtor rural; (2) satisfação pessoal com a atividade agrícola; (3) situação atual da agricultura; (4) preocupação pessoal com a preservação do meio ambiente; e (5) preocupação com a qualidade da própria produção. ${ }^{24}$

\footnotetext{
${ }^{24}$ No Apêndice 2 é apresentada a freqüência absoluta das notas atribuídas a estas questões iniciais, bem como a média e a mediana.
} 
Muito embora nenhum produtor rural atribua a si próprio nota entre zero e quatro, o que o classificaria como um péssimo produtor, alguns foram autocríticos o suficiente para classificarem-se como medianos (notas cinco e seis). Entretanto, a grande maioria dos entrevistados $(74,2 \%)$ considera-se um bom produtor rural, com notas sete ou oito. A nota média atribuída resultou em 7,81, o que permite concluir que estes produtores consideram-se bons, mas ainda acreditam que podem melhorar a condução de sua propriedade ou produção, uma vez que somente 11 entrevistados atribuíram-se nota dez.

Tabela 3. Nota atribuída pelos entrevistados às cinco questões iniciais.

\begin{tabular}{|c|c|c|c|c|c|c|c|c|c|c|}
\hline \multirow[b]{2}{*}{ Nota } & \multicolumn{2}{|c|}{ Questão $1^{1}$} & \multicolumn{2}{|c|}{ Questão $2^{2}$} & \multicolumn{2}{|c|}{ Questão $3^{3}$} & \multicolumn{2}{|c|}{ Questão $4^{4}$} & \multicolumn{2}{|c|}{ Questão $5^{5}$} \\
\hline & Freq. & $\%$ & Freq. & $\%$ & Freq. & $\%$ & Freq & $\%$ & Freq. & $\%$ \\
\hline$\leq$ Quatro & 0 & 0,0 & 5 & 3,6 & 19 & 13,6 & 0 & 0,0 & 0 & 0,0 \\
\hline Cinco & 4 & 2,9 & 11 & 7,9 & 36 & 25,7 & 10 & 7,1 & 1 & 0,7 \\
\hline & 7 & 5 & 8 & 5 & 36 & 25,7 & 1 & 7,1 & & 2,1 \\
\hline Sete & 38 & 27,1 & 15 & 10,7 & 29 & 20,7 & 16 & 11,4 & 12 & 8,6 \\
\hline Oito & 66 & 47,1 & 40 & 28,6 & 12 & 8,6 & 39 & 27,9 & 41 & 29,3 \\
\hline Nove & 14 & 10,0 & 24 & 17,1 & 4 & 2,9 & 24 & 17,1 & 43 & 30,7 \\
\hline Dez & 11 & 7,9 & 37 & 26,4 & 4 & 2,9 & 41 & 29,3 & 40 & 28,6 \\
\hline Total & 140 & 100 & 140 & 100 & 140 & 100 & 140 & 100 & 140 & 100 \\
\hline
\end{tabular}

Fonte: resultados da pesquisa.

${ }^{1}$ nota entre zero e dez para o próprio entrevistado como produtor rural.

${ }^{2}$ nota entre zero e dez para a satisfação pessoal com a atividade agrícola.

${ }^{3}$ nota entre zero e dez para a situação atual da agricultura.

${ }^{4}$ nota entre zero e dez para a preocupação pessoal com a preservação do meio ambiente.

${ }^{5}$ nota entre zero e dez para a preocupação com a qualidade da própria produção.

No que diz respeito à satisfação pessoal com a atividade agrícola, a maior parte dos entrevistados declarou-se satisfeita ou muito satisfeita, atribuindo a esta questão a maioria das notas entre oito e dez. Percebe-se que 
muito embora esteja satisfeito ou realizado com o desempenho de suas atividades, o produtor rural declara-se menos satisfeito com a situação conjuntural da agropecuária, uma vez que a maioria das notas a esta questão está entre cinco e seis. A média da satisfação pessoal com a agricultura foi 8,10 , contra uma média bem mais baixa da situação atual da agricultura, que foi de 5,95. Diante destes dados, conclui-se que embora a situação atual da agropecuária seja motivo de pouca satisfação para os produtores (pois às respostas, seguiram-se comentários do tipo "a agricultura já esteve melhor, mas também já esteve pior"), estes mantém-se satisfeitos com a atividade agrícola uma vez que é de seu domínio e compreensão os aspectos técnicos e administrativos que esta exige.

$\mathrm{Na}$ Tabela 3 também apresenta-se uma síntese das respostas dos produtores com relação à preocupação com a preservação do meio ambiente. Do total de cento e quarenta entrevistados, nenhum produtor declarou-se totalmente despreocupado ou pouco preocupado com a preservação do meio ambiente. Dez entrevistados, que atribuíram nota cinco a esta questão, são indiferentes à preservação ambiental, enquanto a grande maioria declarou-se preocupada ou muito preocupada com o meio ambiente, o que reflete-se na nota média obtida para esta questão: 8,29. Quando da realização das entrevistas, muitos produtores chegaram a mencionar que utilizam a técnica de plantio direto de grãos pois esta, além de menos custosa, seria menos prejudicial ao meio ambiente. O plantio direto é considerado como uma contribuição pessoal à preservação ambiental. Outros mencionaram que vêm realizando a tríplice lavagem e descarte criterioso de embalagens de agroquímicos desde antes da regulamentação legal para estes fins. Certo disto, o produtor rural ainda vincula o descuido com o meio ambiente a um fator que compromete a qualidade de vida da comunidade em que ele se insere e a qualidade do seu produto. 
Por fim, os entrevistados declararam-se bastante preocupados com relação à qualidade dos produtos que são ofertados, uma vez que a média desta questão foi 8,7. Os produtores comentaram que "fazem o que podem para ofertar um bom produto", desde que tal fato não represente acréscimo substancial à estrutura de custos da propriedade.

Questionados sobre a realização de controle financeiro das despesas e custos de produção, $10 \%$ dos produtores responderam que não realizam quaisquer tipos de anotações ou "sabem tudo de cabeça". Um quarto dos entrevistados $(25,7 \%)$ declarou que anota sistematicamente somente os principais valores incorridos e 17,9\% fazem anotação detalhada dos custos com a propriedade. Sessenta e cinco produtores (que representam $46,4 \%$ da amostra de cooperados entrevistados) participam do programa de gerenciamento desenvolvido pela Cotrijal. Ressalte-se que esta característica quanto ao controle financeiro não reflete com propriedade a população de associados à Cooperativa. Isto porque somente cerca de 210 cooperados participam do programa de gerenciamento realizado pela equipe técnica, e a amostra selecionada para entrevista acabou por envolver quantidade substancial destes produtores.

\subsubsection{Análise das atividades administrativas ${ }^{25}$}

Tendo em vista o objetivo de quantificar a importância das diferentes áreas de gerenciamento que compõe a "matriz de atividades administrativas"26, foram elaboradas trinta e duas afirmativas. Foi solicitado a cada um dos entrevistados a atribuição de nota entre zero e dez, dependendo do grau de concordância com cada uma delas. Para a compreensão dos resultados, devese considerar que a nota zero significa total discordância com a afirmação;

${ }^{25}$ O Apêndice 2 apresenta a freqüência absoluta das notas atribuídas pelos entrevistados a cada uma das 32 atividades administrativas pesquisadas, assim como a média e a mediana calculada. 
notas entre um e quatro significam discordância parcial com a frase; nota cinco revela indiferença para com a questão; notas entre seis e nove demonstram concordância parcial com a afirmação; e nota dez reflete concordância integral.

As questões 04 e 26 relacionam-se ao planejamento estratégico e operacional da produção. A afirmativa (04) é "o bom produtor rural faz diversificação da produção para se proteger de frustrações de safras, de preços baixos e diminuir as variações de sua renda", enquanto a afirmação (26) é "o bom produtor rural define o que vai produzir anualmente com base nos preços de mercado" e os resultados obtidos são apresentados na Tabela 4.

Tabela 4. Notas atribuídas pelos entrevistados ao planejamento estratégico e operacional da produção.

\begin{tabular}{lcccc}
\hline & \multicolumn{2}{c}{ Questão $^{1}$ 04 } & \multicolumn{2}{c}{ Questão $^{2} 26$} \\
\cline { 2 - 5 } Notas & Freqüência & Percentual & Freqüência & Percentual \\
\hline Zero & 0 & 0,00 & 5 & 3,57 \\
De um a quatro & 5 & 3,57 & 10 & 7,14 \\
Cinco & 2 & 1,43 & 11 & 7,86 \\
De seis a nove & 72 & 51,43 & 96 & 68,57 \\
Dez & 61 & 43,57 & 18 & 12,86 \\
Total & 140 & 100,00 & 140 & 100,00 \\
\hline
\end{tabular}

Fonte: resultados da pesquisa.

${ }^{1}$ (04) "o bom produtor rural faz diversificação da produção para se proteger de frustrações de safras, de preços baixos e diminuir as variações de sua renda". ${ }^{2}$ (26) "o bom produtor rural define o que vai produzir anualmente com base nos preços de mercado".

A questão 04 trata de fatores que interferem na definição do mix de produção da empresa agropecuária. Esta afirmação sugere que produtor rural utiliza-se da estratégia de diversificação de sua produção, como forma de evitar os problemas fitossanitários que a monocultura gera e minimizar as perdas que

\footnotetext{
${ }^{26}$ Conforme descrito por Canziani (2001).
} 
uma frustração de preços pode gerar no momento de comercialização dos produtos. A mediana calculada para esta questão foi 9 , indicando que os produtores entrevistados acreditam que a diversificação da produção traz benefícios técnicos e contribui para a diminuição das flutuações de renda da propriedade. Um exemplo que foi constantemente citado nas entrevistas foi a integração da lavoura com a pecuária (produção de grãos em conjunto com a criação de aves, suínos, bovinos), permitindo ao produtor a obtenção de renda mensal com a venda de animais ou de leite, além da renda proporcionada pela produção do ano agrícola (renda anual).

Muito embora haja quase um consenso quanto ao planejamento estratégico da produção, revelando que a diversificação é uma estratégia reconhecidamente benéfica, o mesmo não pode ser afirmado com relação ao planejamento operacional. Isto porque, no momento de efetivamente realizar o plantio, acredita-se que os produtores podem alterar o planejamento anterior, ficando entusiasmados com o produto que está com o preço de mercado mais atraente ou elevado. A mediana desta questão foi 8 , indicando que 0 planejamento da produção pode ser modificado de acordo com os preços da última safra. Entretanto a distribuição de freqüência para esta questão demonstra que há controvérsia entre os produtores quanto a este assunto. Alguns entrevistados acreditam que um bom produtor deve manter 0 planejamento de longo prazo, independentemente das oscilações de preço de curto prazo. Uma das razões que podem ser consideradas é a de que não existem garantias de que os preços continuarão favoráveis ou desfavoráveis no momento da próxima colheita. Além disto, fatores técnicos devem ser considerados, como a necessidade técnica de rotação de cultura, o custo de aprendizagem ou de alteração e adaptação da estrutura física da propriedade às novas atividades. A falta de informação ou credibilidade nos analistas de mercado pode levar ao comportamento passivo diante das alterações nos preços, conforme mencionado durante uma das sessões de grupo focal: "os 
analistas fazem as médias dos últimos anos, mas mesmo assim não conseguem acertar os preços. Se os próprios analistas não tem certeza do que estão falando, então, como nós vamos acreditar neles?".

Outros entrevistados, por outro lado, têm a opinião de que não há problema em seguir as diretrizes determinadas pelos preços relativos observados no curto prazo, indicado pelas altas notas atribuídas à questão 26. A alteração no planejamento de longo prazo busca o aproveitamento das oportunidades que o mercado oferece. Provavelmente há produtores bem informados e que acompanham as análises e previsões do mercado, tomando decisões contrárias àquelas anteriormente planejadas, em função dos novos cenários.

As afirmações 17 e 01 relacionam-se, respectivamente, ao planejamento estratégico e operacional da área de finanças da propriedade rural, cuja redação é "o bom produtor tem como objetivo principal do empreendimento rural promover um bom padrão de vida para família (como, por exemplo, dar boa educação para os filhos, ter um bom plano de saúde e dispor de conforto dentro de casa)" e "o bom produtor rural faz planejamento ou orçamento de qual a melhor época de comprar adubo, sementes, defensivos agrícolas".

A Tabela 5 sintetiza as notas obtidas pelas questões 17 e 01 . Mais da metade dos entrevistados concorda que um bom produtor rural tem como objetivo principal promover o bem estar familiar, fato este comprovado com a mediana 10 obtida para esta questão. Os dados reafirmam o que a análise dos grupos focais já sinalizava: o papel da família como um condicionantes das atitudes administrativas tomadas na propriedade rural. Pode-se afirmar, pois, que a promoção da educação para os filhos ou do conforto no lar interfere na estratégia de planejamento da propriedade. Ou seja, há de se considerar que, 
de acordo com esse critério, é possível preterir investimentos na área produtiva ao deslocar-se recursos financeiros para a satisfação de necessidades familiares.

Tabela 5. Notas atribuídas pelos entrevistados ao planejamento estratégico e operacional das finanças.

\begin{tabular}{lcccc}
\hline & \multicolumn{2}{c}{ Questão $^{1} 17$} & \multicolumn{2}{c}{ Questão $^{2} 01$} \\
\cline { 2 - 5 } Notas & Freqüência & Percentual & Freqüência & Percentual \\
\hline Zero & 0 & 0,00 & 0 & 0,00 \\
De um a quatro & 1 & 0,71 & 2 & 1,43 \\
Cinco & 3 & 2,14 & 5 & 3,57 \\
De seis a nove & 60 & 42,86 & 73 & 52,14 \\
Dez & 76 & 54,29 & 60 & 42,86 \\
Total & 140 & 100,00 & 140 & 100,00 \\
\hline
\end{tabular}

Fonte: resultados da pesquisa.

1 (17) "o bom produtor rural tem como objetivo principal do empreendimento promover um bom padrão de vida para família (como, por exemplo, dar boa educação para os filhos, ter um bom plano de saúde e dispor de conforto dentro de casa)".

${ }^{2}$ (01) "o bom produtor rural faz planejamento ou orçamento de qual a melhor época de comprar adubo, sementes, defensivos agrícolas".

Já a questão número 01 procura avaliar se o produtor rural faz planejamento de qual a melhor época de comprar seus insumos agrícolas. A mediana obtida por esta questão foi 9 , indicando que os entrevistados concordam que um produtor de sucesso procura a melhor época para demandar insumos. Entretanto, pode-se compreender de duas formas qual é esta melhor época: uma delas é período em que existem ofertas vantajosas em termos de preço no mercado e outra é no momento em que estes insumos são demandados. 
De modo a aproveitar os melhores preços, o produtor deve planejar-se para ter recursos financeiros disponíveis ao longo de todo o ano e não contar somente com a renda no momento de venda da safra ou com empréstimos (custeio agropecuário). Diante da impossibilidade de adquirir insumos quando os preços estão menores (entressafra), a melhor época para a compra é no momento em que os insumos são demandados dentro do processo produtivo. É preciso, então, atenção do produtor para acompanhar o preço e a quantidade disponível dos insumos no mercado, de modo a evitar queda de produtividade devido à falta de algum produto. Assim, concordam os entrevistados que o planejamento operacional da área financeira é importante para o sucesso de um empreendimento rural. Entretanto torna-se praticamente inviável este planejamento sem a utilização de instrumentos que permitam a compreensão ou a visualização das entradas e saídas de recursos financeiros, tais como o fluxo de caixa ou contabilidade de gastos e custos.

\section{O planejamento estratégico e operacional da área de} comercialização de uma propriedade rural foi avaliado com as questões $12 \mathrm{e}$ 21. A redação da questão 12 é "o bom produtor rural é aquele que deixa para a cooperativa toda a estratégia de comercialização de sua produção" e da 21 é "o bom produtor rural é aquele que vende sua produção apenas quando precisa de recursos financeiros" e as respostas dos entrevistados estão sintetizadas na Tabela 6.

A mediana 8, obtida pela questão 12, indica concordância dos entrevistados com a questão proposta, de que um bom produtor confia na cooperativa a que ele está filiado para a comercialização de seus produtos. Ou seja, pode-se concluir que existe confiança nas estratégias de comercialização das cooperativas em conseguir melhores preços do que o jogo individual no mercado. Esta afirmativa, entretanto, conduziu a resultados cuja validade é controversa, haja visto a distribuição de freqüência apresentada. Alguns 
entrevistados acreditam que um bom produtor rural estabelece sua estratégia de comercialização considerando a cooperativa como uma das alternativas e não como a única ou mais vantajosa; assim é possível ser bem sucedido agindo isoladamente no mercado. Implícito a este raciocínio está a idéia de que um bom produtor pode obter informações sobre o comportamento dos preços dos produtos agrícolas além daquelas de conhecimento da cooperativa. O produtor sabe analisar as informações e tem capacidade e recursos físicos e humanos para montar a própria estratégia comercial, aproveitando as oportunidades do mercado.

Tabela 6. Notas atribuídas pelos entrevistados ao planejamento estratégico e operacional da comercialização.

\begin{tabular}{lcccc}
\hline & \multicolumn{2}{c}{ Questão $^{1} 12$} & \multicolumn{2}{c}{ Questão $^{2} 21$} \\
\cline { 2 - 5 } Notas & Freqüência & Percentual & Freqüência & Percentual \\
\hline Zero & 13 & 9,29 & 6 & 4,29 \\
De um a quatro & 15 & 10,71 & 12 & 8,57 \\
Cinco & 10 & 7,14 & 15 & 10,71 \\
De seis a nove & 71 & 50,71 & 70 & 50,00 \\
Dez & 31 & 22,14 & 37 & 26,43 \\
Total & 140 & 100,00 & 140 & 100,00 \\
\hline
\end{tabular}

Fonte: resultados da pesquisa.

1 (12) "o bom produtor rural é aquele que deixa para a cooperativa toda a estratégia de comercialização de sua produção".

${ }^{2}$ (21) "é aquele que vende sua produção apenas quando precisa de recursos financeiros".

Já no que diz respeito à visão operacional, os entrevistados concordam, pelo menos em parte, que os produtores rurais de sucesso somente vendem sua produção quando necessitam de recursos financeiros. Este tipo de comportamento torna implícita algumas características de um bom produtor rural, a saber: (a) os produtores não aplicam a totalidade de seus recursos em 
ativos de alta liquidez, preferindo trabalhar com estoque físico de produtos; (b) existe, então, preferência pela especulação com relação ao comportamento do preço dos produtos e não com as taxas de juros vigentes no mercado financeiro; diante disto, (c) comprova-se o otimismo dos produtores, uma vez que estes acreditam que esta alternativa significará maior retorno no futuro, ou seja, que o preço sempre irá aumentar. Conforme Canziani (2001), (d) esta atitude contribui para contenção dos gastos familiares, uma vez que já comprovou-se que a família exerce influência considerável na determinação da estratégia financeira; e (e) os produtores consideram os ativos físicos como alternativa para garantia em operações de crédito.

Por fim, o planejamento estratégico e operacional da área de recursos humanos é analisado por meio das afirmativas 14 ("o bom produtor rural sempre delega atividades aos filhos com o objetivo de fazer seu sucessor e dar continuidade a propriedade rural no futuro") e 16 ("o bom produtor rural é aquele que sempre consegue tirar férias e viajar pelo menos uma vez por ano". A síntese das respostas dadas pelos entrevistados é apresentada na Tabela 7.

A mediana 10 obtida pela afirmativa 14 sinaliza a influência da família na condução do planejamento estratégico da propriedade rural. Os entrevistados concordam, pois, que o envolvimento de questões familiares na administração rural pode direcionar as atitudes e decisões de um produtor reconhecidamente bem sucedido. $\mathrm{O}$ bom produtor rural seria então caracterizado pela habilidade e/ou capacidade em envolver os filhos na atividade agrícola por ele desenvolvida. Por um lado, a delimitação de um futuro profissional para os sucessores corrobora as idéias discutidas nos grupos focais, de que um produtor bem sucedido preocupa-se com a educação dos filhos e com a sucessão da propriedade. O envolvimento destes nas rotinas da propriedade pode ser considerado como uma ampliação do conhecimento técnico e prático, que não é transmitido formalmente em cursos técnicos ou superiores. Por outro 
lado, a concordância com a afirmativa reforça a opinião de que um produtor bem sucedido tem orgulho e satisfação com a realização das atividades agropecuárias, ao desejarem transmitir aos filhos os conhecimentos acumulados e os valores pessoais.

Tabela 7. Notas atribuídas pelos produtores ao planejamento estratégico e operacional dos recursos humanos.

\begin{tabular}{lcccc}
\hline & \multicolumn{2}{c}{ Questão $^{1} 14$} & \multicolumn{2}{c}{ Questão $^{2} 16$} \\
\cline { 2 - 5 } Notas & Freqüência & Percentual & Freqüência & Percentual \\
\hline Zero & 0 & 0,00 & 14 & 10,00 \\
De um a quatro & 2 & 1,43 & 12 & 8,57 \\
Cinco & 2 & 1,43 & 19 & 13,57 \\
De seis a nove & 56 & 40,00 & 59 & 42,14 \\
Dez & 80 & 57,14 & 36 & 25,71 \\
Total & 140 & 100,00 & 140 & 100,00 \\
\hline
\end{tabular}

Fonte: resultados da pesquisa.

${ }^{1}(14)$ "o bom produtor rural sempre delega atividades aos filhos com o objetivo de fazer seu sucessor e dar continuidade a propriedade rural no futuro".

${ }^{2}$ (16) "o bom produtor rural é aquele que sempre consegue tirar férias e viajar pelo menos uma vez por ano".

Cabe menção também, que a estratégia de gestão de recursos humanos de fazer o sucessor e dar continuidade à empresa pode estar associada à manutenção da unidade familiar como forma de redução de custos, ao viabilizar a realização de parcerias, condomínios e associações entre familiares, conforme discutido nos grupos focais.

Muito embora os entrevistados reconheçam as características de manutenção da união familiar em um bom produtor rural, não existem garantias de que o envolvimento de familiares na gestão futura da propriedade seja a alternativa mais correta. Esta estratégia de planejamento de recursos humanos pode comprometer o futuro do empreendimento rural, pois os filhos podem não 
ter a vocação do pai para o desenvolvimento das atividades agropecuárias. Ao interferir na escolha profissional dos descendentes, o proprietário poderá manter na atividade rural indivíduos com pouca competência gerencial para tanto. Além deste fato, a adoção desta estratégia contraria a noção de profissionalização da atividade agrícola, que pode ser a alternativa mais vantajosa para a manutenção futura da propriedade.

No que diz respeito ao aspecto operacional do planejamento de recursos humanos, investigada na questão 16, não pode ser detectado um consenso entre os produtores entrevistados. Enquanto alguns concordam que um bom produtor rural consegue tirar férias pelo menos uma vez por ano, outros acreditam que a capacidade de um produtor não está associada com viagens ou férias. O que está refletido nesta afirmativa não é a disponibilidade de recursos financeiros para a realização de viagens e sim as características pessoais do proprietário na gestão de seu negócio e o planejamento e escalonamento de recursos humanos para o desempenho de atividades rotineiras. Ao discordarem desta afirmativa alguns entrevistados concordam que um bom proprietário rural é reconhecido pela maneira centralizadora que conduz suas atividades, ao concentrar em si próprio várias atividades estratégicas e operacionais. Desta forma, ausentar-se da propriedade significaria uma interrupção na determinação e no controle daquilo que deve ser realizado. Talvez pela maneira autocrática com que o proprietário rural exerce sua liderança e por não confiar na capacidade e eficiência dos familiares e empregados na realização das atividades rotineiras, possa ser justificada a falta de empenho em planejar sua saída da propriedade. Assim, a falta de vontade de ausentar-se da propriedade deve-se mais a estas características pessoais do proprietário do que a real necessidade em acompanhar as atividades do diaa-dia. 
Por outro lado, a concordância pelo menos parcial com a afirmativa 16 sugere que, para outros entrevistados, um produtor rural de sucesso deve ser menos centralizador, delegando aos familiares e empregados atividades operacionais. Assim, o planejamento dos recursos humanos envolve a capacitação e o treinamento do pessoal para a realização de operações sem que seja necessária a presença física do proprietário. Desta forma, o planejamento das operações diárias deve incluir não só as rotinas de serviço como também um período de descanso para o produtor, sem que isto signifique o comprometimento da qualidade das atividades realizadas. Muito embora não tenha sido feita uma diferenciação dos entrevistados quanto ao gênero, durante a realização das entrevistas percebeu-se que as mulheres atribuíram notas elevadas a esta questão. Ao concordarem com a afirmativa, as mulheres concordam com a gestão menos centralizadora da propriedade.

\section{A organização da produção em nível estratégico e operacional foi} investigada por meio das afirmativas 05 ("o bom produtor rural sempre adota a estratégia de fazer parceria, associação ou condomínios de produção agropecuária para diminuir os custos de produção e os riscos da atividade agrícola") e 10 ("o bom produtor rural sempre mantém a lavoura com um bom aspecto visual, livre de pragas e doenças e mantém instalações, máquinas e equipamentos limpos e bem conservados").

Pode-se concluir, em acordo com os dados sintéticos reproduzidos na Tabela 8, que os entrevistados reconhecem, pelo menos parcialmente, que um produtor rural bem sucedido adota a estratégia de realização de parcerias, associações ou condomínios de exploração agropecuária. A dispersão de frequência das notas atribuídas a esta questão pode relacionar-se com a experiência pessoal do entrevistado com relação à estratégia considerada. Os produtores entrevistados muitas vezes complementaram as respostas com 
comentários ou exemplos pessoais sobre parcerias ou associações bem sucedidas ou inviabilizadas devido ao conflito entre os envolvidos.

Tabela 8. Notas atribuídas pelos entrevistados à organização estratégica e operacional da produção.

\begin{tabular}{lcccc}
\hline & \multicolumn{2}{c}{ Questão $^{1} 05$} & \multicolumn{2}{c}{ Questão $^{2} 10$} \\
\cline { 2 - 5 } Notas & Freqüência & Percentual & Freqüência & Percentual \\
\hline Zero & 1 & 0,71 & 0 & 0,00 \\
De um a quatro & 12 & 8,57 & 2 & 1,43 \\
Cinco & 24 & 17,14 & 1 & 0,71 \\
De seis a nove & 60 & 42,86 & 56 & 40,00 \\
Dez & 43 & 30,71 & 81 & 57,86 \\
Total & 140 & 100,00 & 140 & 100,00 \\
\hline
\end{tabular}

Fonte: resultados da pesquisa.

1 (05) "o bom produtor rural sempre adota a estratégia de fazer parceria, associação ou condomínios de produção agropecuária para diminuir os custos de produção e os riscos da atividade agrícola".

${ }^{2}$ (10) "o bom produtor rural sempre mantém a lavoura com um bom aspecto visual, livre de pragas e doenças e mantém instalações, máquinas e equipamentos limpos e bem conservados".

A adoção da estratégia de organizar a produção envolvendo terceiros reflete características pessoais de um bom produtor rural. Este tem capacidade e discernimento para identificar novas oportunidades de negócio e reconhecer dentre os demais produtores de sua comunidade aqueles dignos de confiança para o estabelecimento de parcerias. Tem consciência dos benefícios que a realização de atividades em grupo pode surtir em termos de redução de custos, ganho de escala produtiva e aumento do poder de barganha frente a vendedores de insumos e compradores dos produtos. Além de refletir a capacidade e habilidade do produtor rural em organizar-se e trabalhar em grupo, a estratégia de estabelecimento de parcerias e associações demonstra a habilidade do empresário em reconhecer os riscos inerentes à atividade 
agrícola e determinar a alternativa mais vantajosa para lidar com eles, se individualmente ou compartilhando com outros produtores.

Outra característica pessoal de um produtor rural de sucesso, que pode estar refletida no estabelecimento da estratégia produtiva em questão, diz respeito à capacidade de ter uma visão holística do processo produtivo. $\mathrm{O}$ produtor sabe dimensionar os recursos físicos, financeiros e humanos que thes são disponíveis e avaliar se estes são suficientes para a execução dos objetivos planejados. Assim, o estabelecimento de parcerias seria uma forma de complementar os recursos faltantes.

Alguns produtores entrevistados demonstraram a não concordância com a questão 05. Acreditam que um produtor rural bem sucedido é aquele que tem capacidade e recursos físicos, financeiros e pessoais para administrar sua propriedade sem o envolvimento de terceiros. Consideram, pois, que 0 estabelecimento de parceria ou associações comprometeria a independência estratégica de funcionamento da propriedade.

A questão 10 procura avaliar a opinião dos entrevistados quanto à capacidade de organização de um bom produtor rural quanto as operações relacionadas à produção, desde o aspecto fitossanitário da lavoura até a manutenção e conservação de máquinas, equipamentos e instalações. A mediana 10 calculada para esta afirmativa reflete a concordância dos produtores entrevistados.

Por ser a produção agropecuária a principal responsável pela receita da propriedade rural, a boa organização das atividades produtivas reflete-se diretamente no sucesso do empreendimento. Um bom produtor rural é reconhecido como capaz de organizar o sequenciamento das operações, de modo a facilitar a logística e o correto dimensionamento da infra-estrutura física 
da propriedade. Além disto a conservação de máquinas, equipamentos, instalações e benfeitorias reflete a preocupação de um produtor bem sucedido com a diminuição dos custos de depreciação. A manutenção da propriedade com bom aspecto visual pode sugerir que o produtor de sucesso é detalhista, caprichoso e preocupado em promover boas condições de vida aos empregados e familiares que aí residem.

As afirmativas 31 e 11 procuraram identificar a opinião dos entrevistados, sintetizada na Tabela 9, com relação à organização estratégica e operacional da área financeira. São elas: (31) "o bom produtor rural sempre controla seus gastos e sabe analisar os dados levantados (anotados) de modo que torne possível saber qual foi o lucro obtido em cada atividade" e questão 11 "o bom produtor rural sempre possui um sistema de controle, mesmo que simplificado, do tipo entradas e saídas de dinheiro do caixa".

A concordância integral com as afirmativas 31 e 11, por parte de metade dos entrevistados, e parcial, pela outra metade, torna possível concluir sobre a importância da organização financeira para o sucesso de um empreendimento rural. Desta forma, algumas das características que podem ser associadas a um bom produtor rural são o conhecimento e a habilidade em manipular números e dados e sua atitude diante da necessidade de organizá-los. Cabe ressaltar que a organização não necessita envolver ferramentas contábeis elaboradas. Um produtor rural pode adotar a estratégia de organizar suas finanças de forma simplificada e, mesmo assim, ser reconhecidamente bem sucedido. Além do registro dos valores envolvidos, a análise subsequente também pode ser simplificada. Muitas vezes ela resume-se à comparação dos gastos com a receita de venda dos produtos (por exemplo, uma saca de adubo equivale a $n$ sacas de soja colhida). 
Tabela 9. Notas atribuídas pelos entrevistados a organização estratégica e operacional das finanças.

\begin{tabular}{lcccc}
\hline & \multicolumn{2}{c}{ Questão $^{1} 31$} & \multicolumn{2}{c}{ Questão $^{2} 11$} \\
\cline { 2 - 5 } Notas & Freqüência & Percentual & Freqüência & Percentual \\
\hline Zero & 0 & 0,00 & 0 & 0,00 \\
De um a quatro & 2 & 1,43 & 1 & 0,71 \\
Cinco & 3 & 2,14 & 5 & 3,57 \\
De seis a nove & 67 & 47,86 & 70 & 50,00 \\
Dez & 68 & 48,57 & 64 & 45,71 \\
Total & 140 & 100,00 & 140 & 100,00 \\
\hline
\end{tabular}

Fonte: resultados da pesquisa.

${ }^{1}$ (31) "o bom produtor rural sempre controla seus gastos e sabe analisar os dados levantados (anotados) de modo que torne possível saber qual foi o lucro obtido em cada atividade".

${ }^{2}$ (11) "o bom produtor rural sempre possui um sistema de controle, mesmo que simplificado, do tipo entradas e saídas de dinheiro do caixa".

Pode-se vincular, também, um produtor de sucesso a um indivíduo preocupado com a melhoria da estratégia de controle dos gastos ou de realizar anotações mais ou menos sistemáticas. Aquele que reconhece as limitações do registro e análise de gastos por ele praticados e procura aperfeiçoar-se nesta área também pode ser considerado como um bom produtor. Assim, a participação em cursos e eventos a respeito da administração financeira ou a busca de apoio, aconselhamento e opiniões de especialistas são fundamentais para o reconhecimento do comportamento financeiro de sua propriedade.

A questão 13 ("o bom produtor rural sempre é o responsável pelas compras e vendas na propriedade. Só transações de pequenos valores podem ser feitas pelos empregados da propriedade") e a questão 23 ("o bom produtor é aquele que sabe distinguir a boa da má informação quanto a preços e qualidade dos insumos disponíveis no mercado") procuram identificar a opinião dos entrevistados quanto à importância da organização operacional e estratégica da área de comercialização na propriedade rural. 
Tendo em vista as respostas dos entrevistados à afirmativa 13, sintetizadas na Tabela 10, conclui-se que um bom produtor rural pode ser reconhecido como aquele que concentra em si próprio as responsabilidades das atividades relacionadas à comercialização de produtos e insumos. Admitese, portanto, que o sucesso de um empreendimento pode estar associado ao comportamento centralizador do produtor no que diz respeito às atividades de compra e venda. Muito embora a atividade produtiva seja o cerne do processo administrativo na propriedade rural, o resultado financeiro depende muitas vezes da estratégia comercial adotada. Ao concentrar as responsabilidades da comercialização, o produtor é considerado mais apto para tanto do que os familiares e empregados. Assim, o bom produtor rural é tido como capaz de identificar os canais de comercialização, os possíveis credores, vendedores e compradores que perfazem a melhor estratégia comercial.

Tabela 10. Notas atribuídas pelos entrevistados à organização estratégica e operacional da comercialização.

\begin{tabular}{lcccc}
\hline \multirow{2}{*}{ Notas } & \multicolumn{2}{c}{ Questão $^{1} 13$} & \multicolumn{2}{c}{ Questão $^{2} 23$} \\
\cline { 2 - 5 } Zero & Freqüência & Percentual & Freqüência & Percentual \\
De um a quatro & 3 & 2,14 & 0 & 0,00 \\
Cinco & 7 & 5,00 & 1 & 0,71 \\
De seis a nove & 14 & 10,00 & 12 & 8,57 \\
Dez & 67 & 47,86 & 73 & 52,14 \\
Total & 49 & 35,00 & 54 & 38,57 \\
\hline
\end{tabular}

Fonte: resultados da pesquisa.

${ }^{1}$ (13) "o bom produtor rural sempre é o responsável pelas compras e vendas na propriedade. Só transações de pequenos valores podem ser feitas pelos empregados da propriedade".

${ }^{2}$ (23) "o bom produtor é aquele que sabe distinguir a boa da má informação quanto a preços e qualidade dos insumos disponíveis no mercado". 
Em que pese a descrição de um bom produtor como aquele que estimula o envolvimento a família com as atividades agrícolas (conforme já discutido na questão referente ao planejamento estratégico de recursos humanos afirmativa 14), percebe-se ao mesmo tempo a restrição à participação na área comercial. Implícito a isto está a idéia de que um produtor rural concentra a experiência e as estratégias de comercialização que obtiveram sucesso no passado, e que não são de conhecimento dos demais envolvidos. Tal fato é comprovado com as respostas à afirmativa 23 , também sintetizadas na Tabela 10. Reconhece-se, então, um produtor de sucesso pela sua capacidade de discernimento quanto a preço e qualidade dos insumos existentes no mercado.

Diante do mercado oligopolizado de insumos agropecuários, onde os participantes valem-se de estratégias de marketing e comercialização agressivas, a escolha dos produtos mais adequados torna-se uma atividade complexa. Isto porque os agropecuaristas estão expostos à mídia e eventos promocionais, que visam a construção de uma imagem positiva do produto e induzem à aquisição deste. Assim, a capacidade de confiar ou não nas informações disponibilizadas relaciona-se ao sucesso do produtor rural. Implícito a este entendimento está a habilidade e disposição para o aprendizado por parte do produtor. Diante de tantas informações desencontradas quanto ao insumo mais adequado a sua cultura, o produtor de sucesso é vinculado àquele que encontra a alternativa correta, baseando sua decisão na experiência pessoal acumulada ou por meio da opinião de pessoas confiáveis como técnicos e vizinhos. Assim, o bom produtor é receptivo a novas informações sobre a atividade por ele desenvolvida e procura ampliá-las constantemente.

As afirmativas 24 ("o bom produtor rural sempre participa de encontros técnicos, cursos e feiras agropecuárias e estimula seus empregados e familiares a participarem de cursos de capacitação rural") e 18 ("o bom produtor rural deve estar sempre presente na propriedade rural, pois assim ele pode 
acompanhar e participar de perto do desenvolvimento dos trabalhos") procuram identificar a opinião dos entrevistados quanto a organização estratégica e operacional dos recursos humanos.

Com base nas respostas sintetizadas na Tabela 11, percebe-se que a grande maioria dos entrevistados concorda plenamente com o fato de um bom produtor rural buscar o aperfeiçoamento contínuo de sua competência gerencial por meio da participação em encontros técnicos, cursos e feiras agropecuárias. Esta estratégia pode ser justificada tendo em vista o acúmulo de responsabilidades na figura do produtor rural: para produzir bem, precisa saber como produzir; para vender bem, precisa saber onde, quando e como vender; para manter a qualidade da produção, necessita aprimorar a técnica. Daí a necessidade de conhecimento teórico que, aliado à prática do dia-a-dia, configura uma das características do produtor de sucesso. Por outro lado, os entrevistados acreditam também que um bom produtor incentiva a participação de empregados e familiares em eventos informativos. Tal fato demonstra a preocupação do produtor rural em melhorar a qualidade dos recursos humanos disponíveis na propriedade, como estratégia para conseguir aumentos de produtividade e melhoria na qualidade dos produtos ofertados.

Os resultados quantitativos reforçam duas características já mencionadas durante a realização dos grupos focais: o bom produtor tem desejo de ampliar o conhecimento necessário ao desenvolvimento de suas atividades e toma atitudes positivas com relação a isto, tanto em termos pessoais, como no envolvimento dos familiares e empregados. Ao melhorar o nível de conhecimento destes últimos, o produtor de sucesso fixa as bases para que seja possível implantar inovações tecnológicas ou técnicas. Empregados bem preparados têm plenas condições de compreender e utilizar a tecnologia disponível para o desenvolvimento das atividades, e consequentemente, poder assumir tarefas mais complexas. 
Tabela 11. Notas atribuídas pelos entrevistados a organização estratégica e operacional dos recursos humanos.

\begin{tabular}{lcccc}
\hline \multirow{2}{*}{ Notas } & \multicolumn{2}{c}{ Questão $^{1}$ 24 } & \multicolumn{2}{c}{ Questão $^{2} 18$} \\
\cline { 2 - 5 } & Freqüência & Percentual & Freqüência & Percentual \\
\hline Zero & 0 & 0,00 & 0 & 0,00 \\
De um a quatro & 2 & 1,43 & 0 & 0,00 \\
Cinco & 1 & 0,71 & 6 & 4,29 \\
De seis a nove & 53 & 37,86 & 45 & 32,14 \\
Dez & 84 & 60,00 & 89 & 63,57 \\
Total & 140 & 100,00 & 140 & 100,00 \\
\hline
\end{tabular}

Fonte: resultados da pesquisa.

${ }^{1}$ (24) "o bom produtor rural sempre participa de encontros técnicos, cursos e feiras agropecuárias e estimula seus empregados e familiares a participarem de cursos de capacitação rural".

${ }^{2}$ (18) "o bom produtor rural deve estar sempre presente na propriedade rural, pois assim ele pode acompanhar e participar de perto do desenvolvimento dos trabalhos".

Por meio da análise das respostas à questão 18, também reproduzidas na Tabela 11, percebe-se que os entrevistados acreditam que, em termos operacionais, o sucesso de um produtor vincula-se à presença, com assiduidade, deste na propriedade rural. Embora seja reconhecido como um indivíduo que promova condições para a capacitação de familiares e empregados, o produtor deve estar presente durante o desenvolvimento das atividades rotineiras, de modo a poder monitorá-las. Esta possível contradição pode revelar características pessoais de um bom produtor rural: zelo para com a organização da atividade agrícola e desejo pessoal de envolver-se cotidianamente com o trato da terra. A presença constante na propriedade pode sugerir que o bom produtor tem capacidade para reorganizar as atividades a serem desenvolvidas todos os dias, tendo em vista as novas informações, por exemplo quanto ao clima ou à disponibilidade de insumos e equipamentos. 
Assim, tem condições de alterar a sequência de tarefas, de modo a otimizar o aproveitamento dos recursos disponíveis.

A afirmativa 22 diz que "o bom produtor rural sempre adota rapidamente novas técnicas de produção (é inovador) e investe em novas máquinas e equipamentos" e a 27 diz que "o bom produtor rural é aquele que é copiado pelos outros, que serve de exemplo na forma de condução do seu empreendimento". Estas afirmações têm como objetivo identificar a opinião dos entrevistados quanto à direção estratégica e operacional da área de produção. A síntese das respostas é apresentada na Tabela 12.

Tabela 12. Notas atribuídas pelos entrevistados à direção estratégica e operacional da produção.

\begin{tabular}{lcccc}
\hline & \multicolumn{2}{c}{ Questão $^{1} 22$} & \multicolumn{2}{c}{ Questão $^{2} 27$} \\
\cline { 2 - 5 } Notas & Freqüência & Percentual & Freqüência & Percentual \\
\hline Zero & 0 & 0,00 & 0 & 0,00 \\
De um a quatro & 7 & 5,00 & 0 & 0,00 \\
Cinco & 16 & 11,43 & 14 & 10,00 \\
De seis a nove & 77 & 55,00 & 90 & 64,29 \\
Dez & 40 & 28,57 & 36 & 25,71 \\
Total & 140 & 100,00 & 140 & 100,00 \\
\hline
\end{tabular}

Fonte: resultados da pesquisa.

1 (22) "o bom produtor rural sempre adota rapidamente novas técnicas de produção (é inovador) e investe em novas máquinas e equipamentos".

${ }^{2}$ (27) "o bom produtor rural é aquele que é copiado pelos outros, que serve de exemplo na forma de condução do seu empreendimento".

Quase um terço dos entrevistados concorda integralmente que um produtor rural de sucesso sempre adota novas técnicas e tecnologias produtivas. Desta forma, acreditam que o bom produtor rural é inovador e não teme utilizar a tecnologia disponível como estratégia para melhorar a produtividade. Entretanto, a maioria concorda parcialmente com esta afirmativa. 
Para estes, um bom produtor rural é conservador, sempre que possível adota a estratégia de introduzir novas técnicas de produção e novas máquinas e equipamentos, demonstrando acima de tudo atitude positiva para com a melhoria no sistema de produção.

O produtor de sucesso procura cercar-se de todo o conhecimento necessário para a introdução de uma nova técnica antes de adotá-la efetivamente. Conversa com técnicos, participa de cursos e discute com conhecidos e vizinhos. Além disto, o produtor procura ter uma visão sistêmica das conseqüências da introdução da nova técnica ou tecnologia, investigar se tem condições financeiras de suportar a mudança, sem que isto signifique comprometimento da atividade produtiva no longo prazo e identificar se tem recursos físicos e humanos que viabilize a alteração. Pondera também os custos inerentes para sair da atividade produtiva que vem desenvolvendo.

Os entrevistados concordam que um produtor rural de sucesso é admirado pelos demais produtores na forma de condução de seu empreendimento. A mediana 8 calculada para a questão 27 indica que a concordância com a afirmativa é parcial. Se de um lado os agropecuaristas têm condições de identificar quem é um produtor de sucesso, não necessariamente as atitudes deste serão reproduzidas. Desta forma, o produtor de sucesso destaca-se dentre os demais, ou seja, obtém o reconhecimento social enquanto produtor. Acreditam os entrevistados que, na condução da atividade agrícola, o produtor deve ter cautela em reproduzir na própria propriedade o que é realizado pelo produtor modelo. Isto porque as características técnicas da produção podem ser identificadas visualmente e serem facilmente reproduzidas. As estratégias comerciais e financeiras, por outro lado, dificilmente são identificadas e passíveis de serem incorporadas pelos demais produtores. Assim, a boa produtividade é condição necessária para o sucesso de qualquer atividade agrícola. Entretanto a busca a qualquer custo do aumento 
na produtividade poderá levar a empresa a incorrer em riscos para suas áreas financeira e comercial.

A afirmativa 32 diz que "o bom produtor rural sempre toma atitude diante das dificuldades financeiras e não fica esperando passivamente do governo uma solução para os seus problemas" e a questão 07 diz que "o bom produtor rural sempre vende sua produção de acordo com a necessidade de caixa (dinheiro) para pagar os compromissos financeiros". Estas afirmações visam avaliar a direção estratégica e operacional da área de finanças tendo em vista a opinião dos produtores rurais entrevistados.

A grande maioria dos entrevistados, conforme respostas sintetizadas na Tabela 13, concorda que uma característica do bom produtor rural é sua atitude especial diante das dificuldades financeiras. Concordam, pois, que um produtor de sucesso tem iniciativa em procurar soluções para suas necessidades financeiras de curto e longo prazo, sem depender necessariamente da disponibilidade de crédito rural concedido pelo governo. Tal fato demonstra a capacidade e habilidade do bom produtor em encontrar junto a vários agentes do mercado a alternativa mais vantajosa em termos de prazos de recebimento dos recursos, condições de pagamento e taxas de juros praticadas. Contempla a totalidade de opções disponíveis: crédito agrícola em bancos estatais e privados, financiamento por empresas fornecedoras de insumos, cooperativas agrícola ou de crédito.

A afirmativa 07 busca avaliar a habilidade do produtor rural em reconhecer o estoque de produtos como recursos financeiros à sua disposição. Tendo em vista os dados da Tabela 13, constata-se que não houve consenso entre os entrevistados quanto a este assunto. A mediana 8 calculada para a afirmativa, traduz a concordância parcial dos entrevistados. Acreditam estes, então, que um bom produtor tem capacidade de reconhecer a produção como 
estoque de recursos financeiros e tem habilidade em vendê-la de acordo com a necessidade de caixa para saldar os compromissos financeiros. Caso contrário, tem conhecimento e recursos físicos para manter a produção em estoque. Tal fato sugere que um bom produtor contempla a possibilidade de manter 0 produto físico estocado e especular com ganhos de preço. Pode aproveitar para vender sua produção quando aparecem oportunidades de realização de um bom negócio, ou quando julgar que os preços praticados no mercado são atraentes para a comercialização. Este comportamento pode significar, por outro lado, que é reconhecida a falta de habilidade ou capacidade dos produtores em atuarem no mercado financeiro. Pode revelar também um perfil conservador, pois o produtor acredita que pode sempre ganhar na venda, esquecendo-se dos ganhos nas compras. No momento em que pode aproveitar os menores preços de insumos ou outros ativos, o preço de venda dos produtos no mercado também pode estar baixo.

Tabela 13. Notas atribuídas pelos produtores à direção estratégica e operacional das finanças.

\begin{tabular}{lcccc}
\hline & \multicolumn{2}{c}{ Questão $^{1}$ 32 } & \multicolumn{2}{c}{ Questão $^{2}$ 07 } \\
\cline { 2 - 5 } Notas & Freqüência & Percentual & Freqüência & Percentual \\
\hline Zero & 0 & 0,00 & 5 & 3,57 \\
De um a quatro & 0 & 0,00 & 10 & 7,14 \\
Cinco & 7 & 5,00 & 9 & 6,43 \\
De seis a nove & 48 & 34,29 & 80 & 57,14 \\
Dez & 85 & 60,71 & 36 & 25,71 \\
Total & 140 & 100,00 & 140 & 100,00 \\
\hline
\end{tabular}

Fonte: resultados da pesquisa.

1 (32) "o bom produtor rural sempre toma atitude diante das dificuldades financeiras e não fica esperando passivamente do governo uma solução para os seus problemas".

2 (07) "o bom produtor rural sempre vende sua produção de acordo com a necessidade de caixa (dinheiro) para pagar os compromissos financeiros". 
A afirmativa 15 "o bom produtor rural sabe que sem a cooperativa ele acabará na mão de intermediários inescrupulosos ou de grandes empresas na hora de vender sua produção" e a 02 "o bom produtor rural é aquele que acompanha, cotidianamente, os preços de mercado, tanto dos produtos quanto dos insumos" avaliam a direção estratégica e operacional da área de comercialização.

A afirmativa 15 procura avaliar se o bom produtor rural reconhece a importância estratégica da cooperativa para comercialização da produção. Pode-se verificar na Tabela 14 que a grande maioria dos entrevistados concorda pelo menos parcialmente com esta proposição, fato este reforçado pelo resultado 9 calculado para a mediana. $\mathrm{O}$ bom produtor rural reconhece que a presença da cooperativa, como agente atuante no mercado regional, permite a delimitação de uma estratégia de venda de produtos. Ao considerar esta alternativa comercial, o produtor pode sentir-se mais confortável, uma vez que tem mais uma opção de venda, além daquelas disponíveis no mercado. Desta forma, a associação a uma cooperativa pode ser entendida como uma decisão estratégica do bom produtor para a condução da atividade rural. A afiliação pode visar exclusivamente benefícios comerciais e não a participação efetiva numa organização social.

O entrevistados concordam, pelo menos parcialmente, que um bom produtor tem a preocupação cotidiana em acompanhar os preços dos produtos e insumos no mercado. Assim, o sucesso de um produtor estaria vinculado à forma pela qual ele efetivamente põe em prática as estratégias de compra e venda. Um bom produtor deveria, dessa forma, contemplar a comercialização em duas etapas. Em primeiro lugar, deve visualizar os objetivos a serem seguidos, quais as atividades necessárias para alcançá-los e as tarefas a serem desempenhadas. Em seguida, deve comparar os recursos necessários e os disponíveis na propriedade. Daí delimita-se a estratégia de compra e venda. 
Tabela 14. Notas atribuídas pelos entrevistados a direção estratégica e operacional da comercialização.

\begin{tabular}{lcccc}
\hline & \multicolumn{2}{c}{ Questão $^{1} 15$} & \multicolumn{2}{c}{ Questão $^{2}$ 02 } \\
\cline { 2 - 5 } Notas & Freqüência & Percentual & Freqüência & Percentual \\
\hline Zero & 2 & 1,43 & 0 & 0,00 \\
De um a quatro & 3 & 2,14 & 1 & 0,71 \\
Cinco & 11 & 7,86 & 2 & 1,43 \\
De seis a nove & 61 & 43,57 & 73 & 52,14 \\
Dez & 63 & 45,00 & 64 & 45,71 \\
Total & 140 & 100,00 & 140 & 100,00 \\
\hline
\end{tabular}

Fonte: resultados da pesquisa.

${ }^{1}$ (15) "o bom produtor rural sabe que sem a cooperativa ele acabará na mão de intermediários inescrupulosos ou de grandes empresas na hora de vender sua produção".

2 (02) "o bom produtor rural é aquele que acompanha, cotidianamente, os preços de mercado, tanto dos produtos quanto dos insumos".

Como segunda etapa no processo de compra e venda, o bom produtor relaciona quais as prioridades a serem adotadas. Cabe lugar então, ao acompanhamento cotidiano de qual o melhor momento de realizar a compra ou a venda, com base nos preços praticados no mercado, colocando em operação a estratégia anteriormente delimitada. $\mathrm{O}$ acompanhamento de preços é, por si só, uma atividade que reflete a busca de conhecimento do produtor bem sucedido. Mesmo quando não necessita acompanhar os preços, mantém-se atualizado, identificando o comportamento oscilatório dos valores de insumos e produtos.

A direção estratégica e operacional da área de recursos humanos é investigada nas questões 03 , "o bom produtor rural faz com que todos os empregados fiquem sabendo o que foi planejado. Assim, todos sabem o que têm que fazer" e 19 "o bom produtor rural sempre passa as ordens de serviços 
aos empregados de forma clara e direta". Quase metade dos entrevistados concorda com a afirmativa 03 , tendo em vista os resultados sintetizados na Tabela 15. Assim, um produtor rural de sucesso pode ser caracterizado pela adoção de uma estratégia clara de comunicação com os empregados. O bom produtor não é centralizador e busca fazer com que todos os envolvidos no processo compreendam os objetivos a serem perseguidos e tomem atitudes para alcançá-los. Desta forma, o sucesso de um empreendimento rural estaria vinculado à comunicação democrática entre produtores, familiares e empregados, uma vez que a adoção desta estratégia possibilita a troca de informações e a incorporação de novas constatações no dia-a-dia do negócio.

Tabela 15. Notas atribuídas pelos entrevistados à direção estratégica e operacional dos recursos humanos.

\begin{tabular}{lcccc}
\hline & \multicolumn{2}{c}{ Questão $^{1} 03$} & \multicolumn{2}{c}{ Questão $^{2} 19$} \\
\cline { 2 - 5 } Notas & Freqüência & Percentual & Freqüência & Percentual \\
\hline Zero & 0 & 0,00 & 0 & 0,00 \\
De um a quatro & 3 & 2,14 & 0 & 0,00 \\
Cinco & 9 & 6,43 & 5 & 3,57 \\
De seis a nove & 69 & 49,29 & 54 & 38,57 \\
Dez & 59 & 42,14 & 81 & 57,86 \\
Total & 140 & 100,00 & 140 & 100,00 \\
\hline
\end{tabular}

Fonte: resultados da pesquisa.

${ }^{1}$ (03) "o bom produtor rural faz com que todos os empregados fiquem sabendo o que foi planejado. Assim, todos sabem o que têm que fazer".

2 (19) "o bom produtor rural sempre passa as ordens de serviços aos empregados de forma clara e direta".

Para aqueles entrevistados que concordam parcialmente com a afirmativa 3 , um bom produtor rural segue a estratégia de ser menos participativo no relacionamento com empregados. Ao exercer o tipo de liderança impositiva, o produtor centraliza a atividade de planejamento, e transmite aos subordinados as atividades mais rotineiras. Tal estratégia tem a vantagem de permitir ao produtor a reavaliação cotidiana do planejamento das 
atividades, sem que haja uma sobreposição de ordens. Por outro lado pode indicar a falta de confiança na capacidade de entendimento das informações por parte dos empregados.

No que diz respeito ao aspecto operacional da gestão de recursos humanos, a maioria dos entrevistados concorda que um bom produtor rural tem capacidade e habilidade em transmitir ordens aos subordinados. Assim, um produtor de sucesso tem facilidade de comunicação e utiliza a linguagem apropriada no trato com os empregados, possibilitando o pleno entendimento. Atuando desta forma, o produtor aumenta a produtividade dos recursos humanos disponíveis, ao evitar o re-trabalho e ações corretivas, atribuídas à falta de clareza na transmissão de ordens. Outra característica que pode ser atribuída a um produtor bem sucedido é o discernimento para saber o momento exato de repassar ordens aos subordinados, de modo a facilitar seu entendimento e pronta execução. Tal fato demonstra conhecimento dos aspectos produtivos e do papel de cada um dos empregados nas atividades operacionais.

Para avaliar a opinião a respeito da importância do controle estratégico e operacional da área produtiva, foram utilizadas as questões 8 , "o bom produtor consegue produzir com produtividade mais alta e custos mais baixos que seus vizinhos" e 9, "o bom produtor é aquele que sabe, efetivamente, se suas atividades estão dando lucro ou prejuízo". Tendo em vista as respostas sintetizadas na Tabela 16, a maioria dos entrevistados concorda parcialmente com a sugestão de que um bom produtor rural tem condições de obter produtividade mais elevada, a custos mais baixos que os demais.

O produtor de sucesso estaria, portanto, relacionado a um indivíduo muito criterioso na definição da estratégia produtiva a ser seguida. Acreditam, assim, que um bom produtor tem capacidade para compreender os diferentes 
sistemas de produção e os recursos físicos, financeiros e humanos disponíveis em sua propriedade. Tem competência para avaliar qual a estratégia produtiva a ser seguida, face a esta dotação, tal como o aumento na produtividade, mesmo que para tanto sejam incorridos custos adicionais ou controle de custos, sacrificando até certo ponto a produtividade.

Tabela 16. Notas atribuídas pelos entrevistados ao controle estratégico e operacional da produção.

\begin{tabular}{lcccc}
\hline & \multicolumn{2}{c}{ Questão $^{1} 08$} & \multicolumn{2}{c}{ Questão $^{2} 09$} \\
\cline { 2 - 5 } Notas & Freqüência & Percentual & Freqüência & Percentual \\
\hline Zero & 5 & 3,57 & 0 & 0,00 \\
De um a quatro & 4 & 2,86 & 2 & 1,43 \\
Cinco & 14 & 10,00 & 2 & 1,43 \\
De seis a nove & 69 & 49,29 & 49 & 35,00 \\
Dez & 48 & 34,29 & 87 & 62,14 \\
Total & 140 & 100,00 & 140 & 100,00 \\
\hline
\end{tabular}

Fonte: resultados da pesquisa.

${ }^{1}$ (08) "o bom produtor consegue produzir com produtividade mais alta e custos mais baixos que seus vizinhos".

2 (09) "o bom produtor é aquele que sabe, efetivamente, se suas atividades estão dando lucro ou prejuízo".

No que tange aos aspectos operacionais, os entrevistados têm a opinião de que um produtor de sucesso têm condições de saber o resultado final de seus esforços produtivos, ou seja, sabe de fato se as atividades por ele desempenhadas são ou não lucrativas, conforme respostas sintetizadas na Tabela 16. Ressalte-se que este controle muitas vezes é realizado sem a utilização de ferramentas tecnológicas complexas ou recursos contábeis elaborados. O produtor bem sucedido muitas vezes pode assimilar o lucro ou prejuízo da produção por meio de medidas indiretas, tais como o comportamento do patrimônio familiar ao longo do tempo, incrementos na infraestrutura física produtiva ou no parque de máquinas e equipamentos. Outra 
medida indireta de lucratividade é a renda líquida por unidade comercializada de produto ou área cultivada.

O comportamento de um bom produtor rural quanto ao controle estratégico e operacional da área financeira, foi avaliado por meio das questões 30 e 28. São elas: (30) "o bom produtor rural é aquele que faz anotações dos seus gastos e obrigações financeiras de longo prazo" e (28) "o bom produtor rural sempre tem um controle separado dos gastos da família e dos gastos com as atividades da propriedade". A síntese das respostas está na Tabela 17. A mediana 10 , bem como os resultados apresentados na tabela refletem o consenso dos entrevistados quanto à estratégia do bom produtor em promover o controle das obrigações financeiras de longo prazo.

Tabela 17. Notas atribuídas pelos entrevistados ao controle estratégico e operacional das finanças.

\begin{tabular}{lcccc}
\hline & \multicolumn{2}{c}{ Questão $^{1}$ 30 } & \multicolumn{2}{c}{ Questão $^{2}$ 28 } \\
\cline { 2 - 5 } Notas & Freqüência & Percentual & Freqüência & Percentual \\
\hline Zero & 0 & 0,00 & 0 & 0,00 \\
De um a quatro & 1 & 0,71 & 1 & 0,71 \\
Cinco & 4 & 2,86 & 13 & 9,29 \\
De seis a nove & 54 & 38,57 & 66 & 47,14 \\
Dez & 81 & 57,86 & 60 & 42,86 \\
Total & 140 & 100,00 & 140 & 100,00 \\
\hline
\end{tabular}

Fonte: resultados da pesquisa.

1 (30) "o bom produtor rural é aquele que faz anotações dos seus gastos e obrigações financeiras de longo prazo".

2 (28) "o bom produtor rural sempre tem um controle separado dos gastos da família e dos gastos com as atividades da propriedade".

O sucesso do produtor está associado à sua atitude positiva quanto à adoção de um sistema de controle que possibilite saber qual o prazo para quitação dos compromissos futuros como financiamentos, empréstimos e dívidas pendentes. Ao adotar esta estratégia o produtor demonstra a capacidade de programar o 
comportamento futuro dos fluxos de caixa e habilidade em lidar com provisões de débitos futuros.

A afirmativa 28 busca investigar a opinião dos entrevistados quanto ao posicionamento do bom produtor quanto ao controle financeiro das receitas e despesas incorridas no dia-a-dia. Por meio da análise da Tabela 17, percebe-se que enquanto metade dos produtores entrevistados concordam integralmente com esta afirmativa, outra metade concorda parcialmente com ela. A característica que está sendo avaliada nesta questão não é a segregação efetiva dos gastos pessoais e das atividades produtivas. O foco central é a realização do controle financeiro, portanto a atitude positiva quanto ao controle, e a capacitação em termos decisórios que tal controle permite. Desta forma, os entrevistados acreditam que um produtor de sucesso mantém algum tipo de controle de receitas e despesas, mesmo que simplificado. Assim, demonstra ter capacidade para por em prática uma forma de controle financeiro que permita uma visão geral dos gastos efetuados, incluindo-se nestes os gastos pessoais.

As questões 25 e 20 procuram identificar as características do bom produtor rural no que diz respeito ao controle estratégico e operacional da comercialização. São elas: "o bom produtor é aquele que conhece ou procura informações sobre os preços históricos dos produtos (séries históricas de preços)" e "o bom produtor rural sempre procura adquirir insumos a preços menores e compra somente o mínimo necessário".

O entrevistados concordam, pelo menos parcialmente (dados sintetizados na Tabela 18), que um bom produtor tem a preocupação em acompanhar a evolução temporal dos preços dos produtos e insumos. Concordam, pois, que um produtor de sucesso tem o conhecimento dos principais fatores que influenciam a área comercial, e consequentemente o resultado financeiro de sua atividade. Assim, reconhecem que o produtor bem 
sucedido deve deter as informações quanto ao preço praticado no mercado ao longo do tempo. Ressalte-se que o controle destas informações pode ser exercido de forma esporádica e de modo simplificado. Não sendo necessário o registro elaborado e detalhado, é comum o produtor tomar como parâmetro de preços a conversibilidade dos insumos em produtos e vice-versa. Desta forma o produtor tem fácil compreensão do movimento oscilatório dos preços, o que o auxilia na tomada de decisões. Como alternativa, o bom produtor pode buscar informações sobre o comportamento dos preços junto a agentes especializados. Tratam-se de atitudes que facilitam a delimitação de uma estratégia a ser desempenhada para a compra de insumos, máquinas e equipamentos e para a venda de produtos. Permite também o estabelecimento de parâmetros para a realização das atividades comerciais.

Tabela 18. Notas atribuídas pelos entrevistados ao controle estratégico e operacional da comercialização.

\begin{tabular}{lcccc}
\hline & \multicolumn{2}{c}{ Questão $^{1} 25$} & \multicolumn{2}{c}{ Questão $^{2} 20$} \\
\cline { 2 - 5 } Notas & Freqüência & Percentual & Freqüência & Percentual \\
\hline Zero & 0 & 0,00 & 2 & 1,43 \\
De um a quatro & 6 & 4,29 & 3 & 2,14 \\
Cinco & 7 & 5,00 & 3 & 2,14 \\
De seis a nove & 73 & 52,14 & 74 & 52,86 \\
Dez & 54 & 38,57 & 58 & 41,43 \\
Total & 140 & 100,00 & 140 & 100,00 \\
\hline
\end{tabular}

Fonte: resultados da pesquisa.

${ }^{1}$ (25) "o bom produtor é aquele que conhece ou procura informações sobre os preços históricos dos produtos (séries históricas de preços)".

${ }^{2}$ (20) "o bom produtor rural sempre procura adquirir insumos a preços menores e compra somente o mínimo necessário".

Em termos operacionais, acreditam os entrevistados que um bom produtor tem capacidade de analisar os preços dos insumos e determinar se é ou não vantajoso fazer ou manter estoques na sua propriedade, tendo em vista as respostas sintetizadas na Tabela 18. Percebe-se com isto que um produtor 
de sucesso tem conhecimento a respeito do sistema de produção adotado em sua propriedade, sabendo identificar a quantidade e o momento exato em que os diferentes insumos devem ser incorporados ao processo produtivo. Assim, o acompanhamento do comportamento do mercado de insumos reflete a preocupação do produtor em manter a produtividade de sua atividade, provendo insumos quando são necessários. Reflete também a capacidade para gestão financeira, uma vez que o produtor de sucesso sabe identificar quais as ofertas de insumos mais vantajosas e sabe dimensionar o caixa para efetuar as compras (contando com recursos próprios ou de terceiros).

Por fim, as questões 6 e 29 objetivam identificar o comportamento dos bons produtores frente ao controle estratégico e operacional dos recursos humanos. A afirmativa 6 é "o bom produtor rural é aquele que conhece bem as pessoas que trabalham em sua propriedade" e a 29 é "o bom produtor rural sempre zela pela sua imagem visual".

Tendo em vista a síntese das respostas apresentada na Tabela 19 e a mediana (dez) calculada para a questão 6, pode-se concluir que os entrevistados vinculam um produtor de sucesso àquele que procura cercar-se de empregados que melhor satisfaçam as exigências das atividades requeridas. Para tanto, o bom produtor sabe sintetizar qual o tipo de conhecimento e habilidade necessária ao empregado, para que este cumpra prontamente as atividades que lhe serão atribuídas. Procura informar-se junto a conhecidos e vizinhos quanto à oferta de profissionais que melhor satisfaçam as exigências das atividades requeridas, sabendo identificar também quais opiniões podem ser confiáveis e quais podem ser descartadas. Assim, um produtor bem sucedido adota a estratégia de cercar-se de todas as informações pertinentes quanto à capacidade e idoneidade dos empregados que trabalham ou podem vir a trabalhar em sua propriedade. Conhecendo a qualidade dos recursos 
humanos que lhes são disponíveis, tem condições de organizar as atividades, e de dividir e atribuir responsabilidades aos empregados.

Tabela 19. Notas atribuídas pelos entrevistados ao controle estratégico e operacional dos recursos humanos.

\begin{tabular}{lcccc}
\hline & \multicolumn{2}{c}{ Questão $^{1} 06$} & \multicolumn{2}{c}{ Questão $^{2} 29$} \\
\cline { 2 - 5 } Notas & Freqüência & Percentual & Freqüência & Percentual \\
\hline Zero & 0 & 0,00 & 1 & 0,71 \\
De um a quatro & 2 & 1,43 & 4 & 2,86 \\
Cinco & 1 & 0,71 & 19 & 13,57 \\
De seis a nove & 46 & 32,86 & 64 & 45,71 \\
Dez & 91 & 65,00 & 52 & 37,14 \\
Total & 140 & 100,00 & 140 & 100,00 \\
\hline
\end{tabular}

Fonte: resultados da pesquisa.

1 (06) "o bom produtor rural é aquele que conhece bem as pessoas que trabalham em sua propriedade".

${ }^{2}$ (29) "o bom produtor rural sempre zela pela sua imagem visual".

A afirmativa 29 procura identificar qual o posicionamento do produtor de sucesso frente à sociedade. Os entrevistados não apresentaram consenso, atribuindo maior ou menor importância a esta questão. Entretanto a maioria dos entrevistados acredita que um produtor de sucesso preocupa-se, pelo menos um pouco, com a imagem visual que desperta na comunidade em que ele está inserido. Conforme já discutido nas sessões de grupo focal, muitas vezes um bom produtor é reconhecido como tal pela sociedade, com base em seus atributos pessoais, que podem ser identificados visualmente. Assim, uma das características que podem ser vinculadas ao produtor de sucesso é a preocupação em tomar atitudes que permitam manter sua imagem perante a sociedade.

Ressalte-se que a imagem visual que um bom produtor deseja imprimir à sociedade pode centrar-se na posse de bens materiais pessoais (como boa 
vestimenta, casa, automóveis) ou no comportamento rotineiro em sociedade. Assim, o produtor de sucesso pode pautar seu comportamento em atitudes socialmente aceitas, como a ausência de vícios como jogos de azar, álcool e drogas. Sabe posicionar-se adequadamente nas diferentes ocasiões (no banco ou financeira, em eventos comemorativos e sociais, no relacionamento com autoridades, etc.), uma vez que sabe que este comportamento acaba por determinar sua credibilidade e aceitação em determinados agrupamentos sociais.

\subsection{Análise dos fatores que caracterizam um bom produtor rural}

\subsubsection{Considerações Iniciais}

Neste item são apresentadas as considerações realizadas inicialmente para determinação dos fatores que caracterizam o sucesso de um produtor rural. Isto porque a análise conjunta de todas as variáveis consideradas importantes pelos produtores rurais entrevistados, quanto às atividades administrativas a serem desempenhadas é de difícil manipulação. Desta forma a sumarização dos dados por meio da análise fatorial possibilita a redução das variáveis a serem analisadas em fatores, viabilizando a análise.

Tendo em vista o esquema analítico proposto por Hair et al. (1998), uma etapa preliminar deve contemplar a adequação da análise fatorial para obtenção de resultados consistentes. Para tanto verifica-se o valor do teste de esfericidade de Bartlett (Bartlett test of sphericity), que testa se a matriz de correlação, calculada com as notas atribuídas às 32 atividades administrativas, é uma matriz identidade. Ou seja, este teste verifica se cada variável correlaciona-se consigo própria $(r=1)$ e não correlaciona-se com as demais $(r=0)$. A obtenção de valores altos favorecem a rejeição desta hipótese, ou seja, as variáveis são correlacionadas umas com as outras e adequadas ao processo de análise fatorial. Para os dados considerados neste trabalho, pode-se rejeitar 
a hipótese de que as variáveis originais não são correlacionadas, tendo em vista o valor obtido no teste $(1.792,4319)$.

Um outro teste que pode ser aplicado é denominado medida de adequacidade da amostra de Kaiser-Meyer-Olkin (KMO - Kaiser-Meyer-Olkin measure of sampling adequacy). Valores pequenos da estatística KMO indicam que correlações entre pares de variáveis não podem ser explicados pelas demais variáveis, tornando a análise fatorial um processo inadequado. $O$ resultado obtido na estatística KMO (0,80359), considerando-se os dados deste trabalho, indica que a análise fatorial é uma ferramenta apropriada para a sumarização das variáveis. Sharma (1996) considera o resultado calculado como um indício de que a análise fatorial é um método apropriado e Hair et al. (1998) o consideram meritório.

O próximo passo a ser seguido, atestada a adequação da análise fatorial para fins deste trabalho, envolve a seleção de um método para obtenção de fatores. Diferentes abordagens podem ser utilizadas; a mais comum e que foi utilizada é denominada método de componentes principais, cuja preocupação central é a determinação do número mínimo de fatores que respondem pela máxima variância dos dados originais. A etapa seguinte envolve a determinação de um número reduzido de fatores, que expressam de forma apropriada a totalidade das variáveis consideradas. Para determinação do número de fatores a serem utilizados, diversos são os processos sugeridos pela literatura; entre eles podem ser citados: (a) determinação a priori, com base em hipóteses teóricas; (b) com base nos autovalores ou raízes características (eigenvalues) calculados maiores que a unidade; (c) pelo cálculo do percentual de variância total acumulada explicada pelos fatores; e (d) pelo gráfico de declive (scree plot) (Hair et al.,1998, Hoffmann, 1999 e Sharma, 1996). 
Diante das alternativas para determinação dos fatores, obtém-se diferentes conclusões a respeito do número de fatores a ser analisado. Oito são os fatores, se forem considerados aqueles com autovalor maior que a unidade. Isto porque o autovalor representa a variância total explicada por cada fator; valores superiores à unidade significam que o fator tem capacidade de explicação maior do que os demais fatores calculados.

Tendo em conta a variância total explicada pelos fatores, que deve ser superior a $60 \%$ conforme Malhotra (2001, p.508), este trabalho deveria analisar também oito fatores. Por meio da análise do gráfico de declive, apresentado na Figura 4, seriam considerados 9 fatores. É necessário ressaltar que este gráfico representa os autovalores (eigenvalues) versus o número de fatores (factor number) obtidos por ordem de extração.

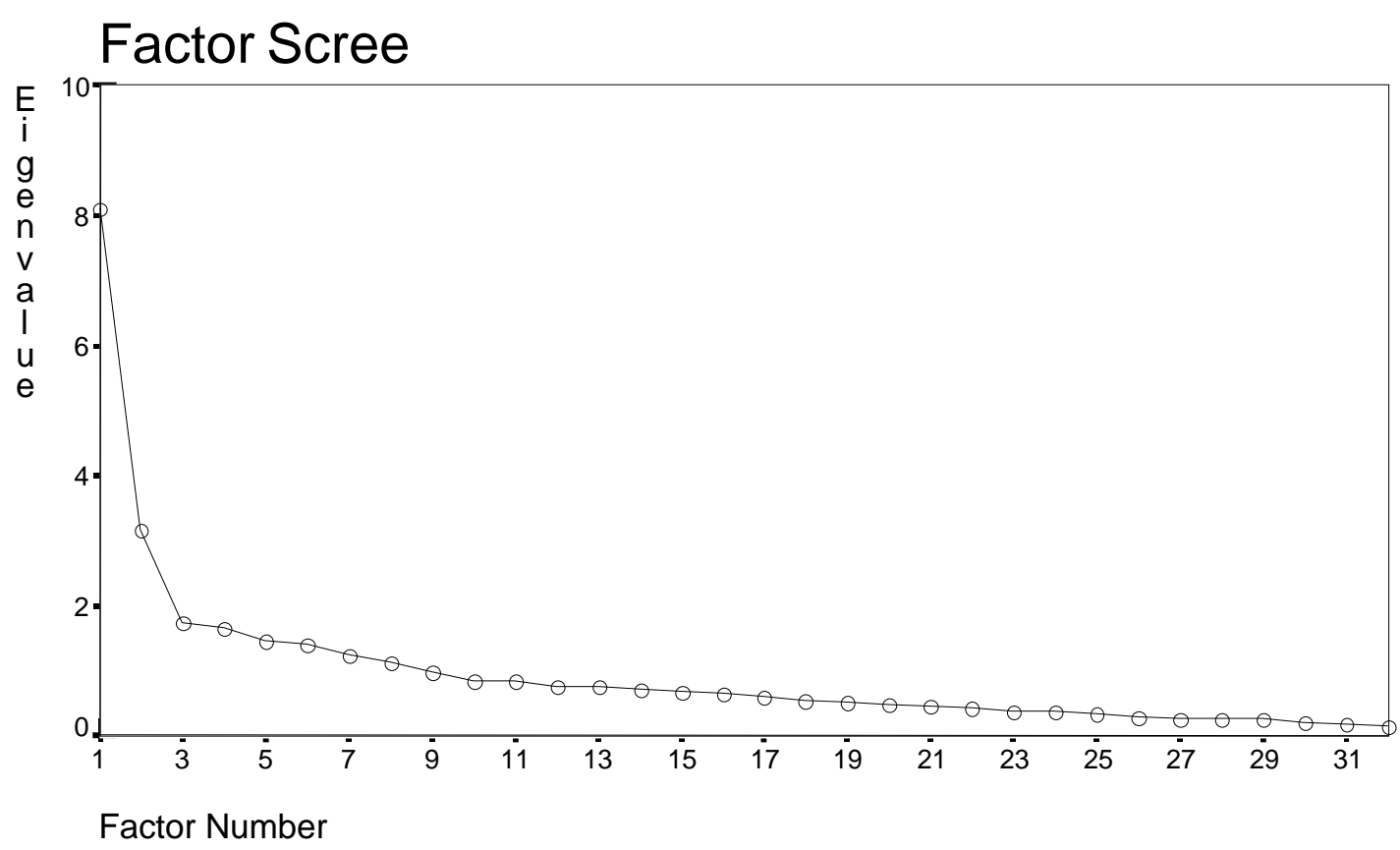

Figura 4 - Gráfico de declive. 
Regras rígidas a respeito do número de fatores podem conduzir a resultados pouco precisos ou com pouca aplicação prática. Já alertam Hair et al. (1998) que a escolha de um número elevado de fatores a serem analisados pode conduzir à grande dificuldade de interpretação dos resultados obtidos. Assim, o presente trabalho optou por considerar como explicativos das características de um bom produtor rural os oito primeiros fatores, que juntos respondem por $62,3 \%$ da variância total das variáveis. ${ }^{27}$

Após a decisão sobre o número de fatores a serem considerados, um processo de rotação foi aplicado. O objetivo da rotação dos fatores é obter uma estrutura mais simples que possa facilitar a interpretação dos fatores, isto é, obter uma nova matriz de coeficientes, de maneira que os valores absolutos dos elementos de cada coluna dessa matriz se aproximem, o máximo possível, de zero ou 1. Assim, a variância explicada pelos fatores é redistribuída por meio da rotação. Isto porque cada fator, após a rotação, deverá apresentar correlação relativamente forte com uma ou mais variáveis e correlação relativamente fraca com as demais variáveis (Hoffmann, 1999). O processo varimax, utilizado neste trabalho é um método de rotação ortogonal ${ }^{28}$, que minimiza o número de variáveis com cargas altas sobre um fator, reforçando as cargas de outras variáveis. Com tal procedimento percebe-se com quais variáveis os fatores estão relacionados, tornando a interpretação dos mesmos mais simplificada.

${ }^{27}$ Conforme Hair et al. (1998, p. 104), nas ciências sociais é comum a utilização de um número de fatores responsáveis pela explicação de cerca de $60 \%$ da variância total. Em contraste, nas ciências naturais é pouco comum a utilização de determinado número de fatores que não respondam por menos de $90 \%$ da variância total.

28 Tal tipo de rotação mantém o ortogonalidade entre os fatores, ou seja, faz com que os mesmos, após a rotação sejam não correlacionados entre si. Segundo Hoffmann (1999), o método de rotação varimax é um dos mais utilizados. 


\subsubsection{Interpretação dos fatores ${ }^{29}$}

A interpretação dos fatores calculados é, talvez, a parte mais importante da análise fatorial. Muito embora não exista uma regra rígida para análise das relações dos fatores com as variáveis, é dispensada maior atenção àquelas variáveis com cargas fatoriais superiores, em valor absoluto, a 0,6 como um indicativo de correlação entre a variável e o fator em análise.

Os oito fatores considerados neste trabalho são sintetizados nos Quadros 5 e 6 . Apresenta-se nestes quadros as atividades administrativas relacionadas ao fator, segundo a seguinte legenda: a primeira letra diz respeito à função administrativa ( $\mathrm{P}=$ planejamento, $\mathrm{O}=$ =organização, $\mathrm{D}=$ direção $\mathrm{e}$ $\mathrm{C}=$ controle), a segunda refere-se ao nível de atuação ( $\mathrm{E}=$ estratégico e $\mathrm{O}=$ operacional) e a última relaciona-se às áreas administrativas ( $\mathrm{P}=$ produção, $F=$ finanças, $C=$ comercialização e $R=$ recursos humanos). Na seqüência é apresentada a carga fatorial e o número e a redação da afirmativa que consta no questionário e serviu para captar a opinião dos entrevistados a respeito de cada atividade administrativa.

O primeiro fator responde por $25,3 \%$ da variância total. Observando os valores das cargas fatoriais existentes na matriz de fatores, percebe-se que este é correlacionado positivamente com as variáveis controle estratégico das finanças (CEF), controle operacional das finanças (COF), direção estratégica das finanças (DEF), organização estratégica das finanças (OEF) e organização operacional das finanças (OOF). Denomina-se este de fator financeiro, uma vez que compreende as funções administrativas de controle, direção e organização em nível estratégico e operacional da área financeira.

\footnotetext{
${ }^{29}$ As cargas fatoriais calculadas para os oito fatores analisados, os autovalores (eigenvalues) e o percentual de variância explicado por estes são apresentadas no Apêndice 3.
} 


\begin{tabular}{|c|c|c|c|}
\hline FATOR 1 & FATOR 2 & FATOR 3 & FATOR 4 \\
\hline $\begin{array}{l}\mathrm{CEF}^{30} \\
\text { O,73560 } \\
\text { 30) O bom produtor rural é } \\
\text { aquele que faz anotações } \\
\text { dos seus gastos e } \\
\text { obrigações financeiras de } \\
\text { longo prazo }\end{array}$ & $\begin{array}{l}\text { DOF } \\
0,77742 \\
7) \text { O bom produtor rural } \\
\text { sempre vende sua } \\
\text { produção d e acordo com } \\
\text { a necessidade de caixa } \\
\text { (dinheiro) para pagar os } \\
\text { compromissos } \\
\text { financeiros. }\end{array}$ & $\begin{array}{l}\text { CER } \\
0,76944 \\
6) \text { O bom produtor rural é } \\
\text { aquele que conhece bem } \\
\text { as pessoas que } \\
\text { trabalham em sua } \\
\text { propriedade. }\end{array}$ & $\begin{array}{l}\text { POR } \\
0,63589 \\
16) \text { O bom produtor rural } \\
\text { é aquele que sempre } \\
\text { consegue tirar férias e } \\
\text { viajar pelo menos uma } \\
\text { vez por ano. }\end{array}$ \\
\hline $\begin{array}{l}\text { DEF } \\
0,71452 \\
\text { 32) O bom produtor rural } \\
\text { sempre toma atitude } \\
\text { diante das dificuldades } \\
\text { financeiras e não fica } \\
\text { esperando passivamente } \\
\text { do governo uma solução } \\
\text { para os seus problemas. }\end{array}$ & $\begin{array}{l}\text { PEC } \\
0,79518 \\
\text { 12) O bom produtor rural } \\
\text { é aquele que deixa para a } \\
\text { cooperativa toda a } \\
\text { estratégia } \\
\text { comercialização de sua } \\
\text { produção. }\end{array}$ & $\begin{array}{l}\text { DER } \\
0,63186 \\
\text { 3) O bom produtor rural } \\
\text { faz com que todos os } \\
\text { empregados fiquem } \\
\text { sabendo o que foi } \\
\text { planejado. Assim, todos } \\
\text { sabem o que têm que } \\
\text { fazer. }\end{array}$ & $\begin{array}{l}\text { PEF } \\
0,75440 \\
17) \text { O bom produtor rural } \\
\text { tem como objetivo } \\
\text { principal do } \\
\text { empreendimento rural } \\
\text { promover um bom padrão } \\
\text { de vida para família } \\
\text { (como, por exemplo, dar } \\
\text { boa educação para os } \\
\text { filhos, ter um bom plano } \\
\text { de saúde e dispor de } \\
\text { conforto dentro de casa). }\end{array}$ \\
\hline $\begin{array}{l}\text { COF } \\
0,73911 \\
28) \text { O bom produtor rural } \\
\text { sempre tem um controle } \\
\text { separado dos gastos da } \\
\text { família e dos gastos com as } \\
\text { atividades da propriedade. }\end{array}$ & $\begin{array}{l}\text { POC } \\
0,72341 \\
21) \text { O bom produtor rural } \\
\text { é aquele que vende sua } \\
\text { produção apenas quando } \\
\text { precisa de recursos } \\
\text { financeiros. }\end{array}$ & $\begin{array}{l}\text { DOC } \\
0,65052 \\
\text { 2) O bom produtor rural é } \\
\text { aquele que acompanha } \\
\text { cotidianamente os } \\
\text { preços de mercado, tanto } \\
\text { dos produtos quanto dos } \\
\text { insumos. }\end{array}$ & \\
\hline $\begin{array}{l}\text { OEF } \\
0,73359 \\
\text { 31) O bom produtor rural } \\
\text { sempre controla seus } \\
\text { gastos e sabe analisar os } \\
\text { dados levantados } \\
\text { (anotados) de modo que } \\
\text { torne possível saber qual } \\
\text { foi o lucro obtido em cada } \\
\text { atividade }\end{array}$ & & & \\
\hline $\begin{array}{l}\text { OOF } \\
0,62366 \\
\text { 11) O bom produtor rural } \\
\text { sempre possui um } \\
\text { sistema de controle, } \\
\text { mesmo que simplificado, } \\
\text { do tipo entradas e saídas } \\
\text { de dinheiro do caixa. }\end{array}$ & & & \\
\hline
\end{tabular}

Quadro 5 - Identificação das afirmativas, e respectivas variáveis, que compõem os cinco principais fatores.

Fonte: resultados da pesquisa.

${ }^{30}$ CEF indica Controle (C) Estratégico $(E)$ das Finanças $(F)$. A primeira letra indica a função administrativa, a segunda indica o nível (estratégico ou operacional) e a terceira a área administrativa. 


\begin{tabular}{|c|c|c|c|}
\hline FATOR 5 & FATOR 6 & FATOR 7 & FATOR 8 \\
\hline $\begin{array}{l}\text { OOR } \\
0,69588 \\
\text { 18) O bom produtor rural } \\
\text { deve estar sempre } \\
\text { presente na propriedade } \\
\text { rural, pois assim ele pode } \\
\text { acompanhar e participar } \\
\text { de perto } \\
\text { desenvolvimento do dos } \\
\text { trabalhos. }\end{array}$ & $\begin{array}{l}\text { OEP } \\
0,70093 \\
5 \text { ) O bom produtor rural } \\
\text { sempre adota a estratégia } \\
\text { de fazer parceria, } \\
\text { associação ou } \\
\text { condomínios de produção } \\
\text { agropecuária para } \\
\text { diminuir os custos de } \\
\text { produção e os riscos da } \\
\text { atividade agrícola. }\end{array}$ & $\begin{array}{ll}\text { COC } & \\
0,63960 & \\
\text { 20) O bom produtor rural } \\
\text { sempre procura } & \text { adquirir } \\
\text { insumos a preços } \\
\text { menores e } & \text { compra } \\
\text { somente o mínimo } \\
\text { necessário. }\end{array}$ & $\begin{array}{l}\text { OEC } \\
0,65831 \\
\text { 13) O bom produtor rural } \\
\text { sempre é o responsável } \\
\text { pelas compras e vendas } \\
\text { na propriedade. Só } \\
\text { transações de pequenos } \\
\text { valores podem ser feitas } \\
\text { pelos empregados da } \\
\text { propriedade. }\end{array}$ \\
\hline $\begin{array}{l}\text { PER } \\
\text { O,84648 } \\
\text { 14) O bom produtor rural } \\
\text { sempre delega atividades } \\
\text { aos filhos com o objetivo } \\
\text { de fazer seu sucessor e } \\
\text { dar continuidade a } \\
\text { propriedade rural no } \\
\text { futuro. }\end{array}$ & & $\begin{array}{l}\text { POP } \\
0,66206 \\
26) \text { O bom produtor rural } \\
\text { define o que vai produzir } \\
\text { anualmente com base } \\
\text { nos preços de mercado. }\end{array}$ & \\
\hline
\end{tabular}

Quadro 6 - Identificação das afirmativas, e respectivas variáveis, que compõem os três últimos fatores.

Fonte: resultados da pesquisa.

A importância deste fator para identificar um bom produtor rural reside no caráter holístico desta atividade. Isto porque a análise das condições financeiras permite a compreensão do empreendimento rural como um todo. $\mathrm{Ou}$ seja, sintetiza quais as conseqüências em termos financeiros, decorrentes da adoção de determinada estratégia ou operação nas demais áreas administrativas: produção, comercialização e recursos humanos. Se as finanças da empresa estão bem, significa que as inter-relações entre as diferentes áreas da empresa estão obtendo os resultados esperados. Assim, pode-se afirmar que, da mesma forma como as demais áreas administrativas influenciam a área financeira, a determinação de estratégias e operações práticas em termos produtivos, comerciais e de recursos humanos dependem do comportamento do produtor rural diante da área de finanças.

Como explicar o papel fundamental das finanças na determinação ou classificação dos agricultores como bem ou mal sucedidos? A teoria da administração nos ensina que é fundamental para o bom produtor tomar 
conhecimento da situação atual e das perspectivas futuras da área financeira de sua empresa. Também é importante a existência ou manutenção de algum tipo de registro ou controle de receitas e gastos com a propriedade. O controle deve conter as informações necessárias para cumprir um duplo papel: no dia-adia deve possibilitar ao produtor a análise dos valores de modo a evitar desvios dos objetivos traçados para a empresa, assim como servir de subsídio para a delimitação ou reorganização de atividades e tarefas. No longo prazo deve permitir a determinação do resultado final obtido pela atividade agrícola.

Cabe ressaltar que a maior ou menor complexidade do sistema de controle financeiro adotado depende de dois fatores: da necessidade pessoal do produtor rural e da capacidade deste em analisar estas informações. De nada vale um sistema de informações detalhado ou complexo se, em termos operacionais, não houver conhecimento suficiente para alimentá-lo ou para entendê-lo. Um controle simplificado de entrada e saída de recursos financeiros pode ser suficiente para o controle cotidiano. Cabe mencionar, entretanto, que o produtor bem sucedido tem preocupação com o controle e a análise financeira, tomando atitudes positivas para aperfeiçoar o sistema ou para aprofundar as conclusões, por meio da participação em cursos de capacitação financeira ou consulta a especialistas desta área.

O resultado financeiro da atividade agrícola tem não só o objetivo de sinalizar o comportamento presente como para delimitar as estratégias a serem adotadas no futuro e à permanência ou saída da empresa da atividade. Assim, ao lado dos resultados presentes, o produtor deve ter visão das fontes futuras de recursos financeiros, bem como dos prazos de recebimento, pagamento e taxas de juros vigentes nas obrigações financeiras. $\mathrm{O}$ bom produtor rural deve, então, controlar, analisar e gerenciar o comportamento das finanças da atividade agrícola no curto e no longo prazo. 
Ao mesmo tempo o gerenciamento financeiro deve contemplar alguma alternativa para mensuração do comportamento dos gastos pessoais. $O$ controle dos gastos deve permitir a identificação daqueles destinados a fins particulares, como forma de objetiva de verificar a interferência da família no desenvolvimento das estratégias administrativas. Isto porque a drenagem de recursos financeiros para atividades não relacionadas com a produção pode sinalizar o comprometimento do crescimento da propriedade no longo prazo.

Adicionalmente, pode-se ressaltar que o fator financeiro abrange também características pessoais do bom produtor rural, além da visão sistêmica do comportamento das finanças no presente e no futuro. Envolve também a capacidade e a habilidade em reunir e analisar as finanças pessoais e 0 conhecimento (mesmo que limitado) do funcionamento do mercado financeiro. Outras características pessoais incorporam a atitude pró-ativa face as necessidades de recursos e a habilidade em negociar prazos e valores com os agentes financeiros existentes no mercado.

Resumindo esta discussão teórica, e tendo em vista a importância encontrada para o fator financeiro, evidencia-se a necessidade de competência do produtor rural em administrar recursos financeiros próprios e de terceiros, como forma de viabilizar a implantação de estratégias produtivas, comerciais e de recursos humanos. Assim, o acompanhamento cotidiano do fluxo de caixa gera subsídios para a organização das tarefas e as alternativas financeiras para realizá-las. O controle das finanças no longo prazo possibilita a compreensão dos resultados e a continuidade na atividade agropecuária.

Respondendo por 9,9\% da variância total das variáveis, o segundo fator extraído após a rotação varimax, relaciona-se positivamente com as atividades administrativas de direção operacional das finanças (DOF), planejamento estratégico da comercialização (PEC) e planejamento operacional da 
comercialização (POC). Denominando-o de planejamento comercial, este fator relaciona-se ao conhecimento e habilidade do bom produtor rural em utilizar estratégias comerciais para obtenção de resultados financeiros.

Analisando as três afirmativas que compõem o fator 2 pode-se inferir que o produtor de sucesso é caracterizado pela delimitação de uma estratégia comercial, à qual incorpora diferentes canais disponíveis para a comercialização de sua produção. O produtor contempla as várias alternativas: compra e venda direta no mercado, por meio de empresas privadas ou cooperativas; obtenção de insumos junto a fornecedores com o compromisso de entrega futura de produtos; integração vertical; utilização de mercado futuro; etc. Assim, tem conhecimento para identificar as vantagens e desvantagens de cada canal de comercialização. Ressalte-se que a cooperativa à qual o produtor está afiliado é considerada por este como uma alternativa confiável para compra e venda, e não a única estratégia disponível ou mais vantajosa em termos financeiros.

Segundo a teoria, o bom produtor deve ter conhecimento técnico e prático suficiente para analisar os prós e contras de cada alternativa comercial e montar sua estratégia. Assim, deve ser um indivíduo que busca constantemente informações sobre os produtos e insumos e tem, portanto, habilidade em negociar com diferentes agentes quanto a preços e prazos. Além disto, o fator planejamento comercial envolve a capacidade do bom produtor em reconhecer a produção como estoque de recursos financeiros e saber dispor destes no momento mais adequado. Demonstra habilidade para vender sua produção diante das diversas ofertas.

As respostas às três afirmativas que compõem o fator 2 permite, ainda, inferir que o bom produtor prefere atuar com cautela no mercado financeiro, especulando com o preço dos produtos mais do que com as taxas de juros. 
Talvez esta característica vincule-se ao comportamento conservador do produtor, ao preferir apostar em alternativas mais palpáveis. Isto porque o produtor tem mais conhecimento a respeito do comportamento do mercado físico do que sobre o mercado financeiro (talvez uma razão vinculada ao baixo volume de contratos futuros de commodities) e prefere trocar os ativos físicos por moeda somente quanto dela necessita para comprar insumos ou outros ativos físicos. Implícito a isto, está a capacidade do bom produtor em dispor de recursos financeiros que viabilizem a manutenção de estoques, ou seja, para evitar que toda a produção seja comercializada durante a safra, quando os preços são menores.

Uma das afirmações que compõe o fator 2 (o bom produtor rural é aquele que vende sua produção apenas quando precisa de recursos financeiros) indica um certo otimismo dos agricultores (o produtor acredita que o preço dos produtos irá aumentar). Além disso, como discutido anteriormente, pode mostrar preocupação com a influência da família na gestão financeira (a manutenção do estoque físico pode contribuir para a contenção dos gastos da família), além da possibilidade de utilização dos produtos como garantia de operações de crédito.

O terceiro fator calculado concentra $5,5 \%$ do total de variância observada entre as variáveis originais. Relaciona-se positivamente com o controle (CER) e direção estratégica de recursos humanos (DER) na propriedade rural, bem como com a direção operacional da comercialização (DOC). Analisando conjuntamente as afirmações que serviram para testar as três atividades administrativas envolvidas, convencionou-se chamar este fator de comunicação e informação, fundamental tanto na gestão de recursos humanos como na delimitação das operações comerciais. 
Sabe-se que o bom produtor tem capacidade de fixar objetivos a serem alcançados com a atividade agrícola e determinar quais os recursos físicos, financeiros e humanos são necessários para desempenhar as tarefas rotineiras. Ele pode avaliar, então, se tem condições de levar adiante as estratégias fixadas ou se precisa incorporar novos recursos (incluindo recursos de terceiros). Como o eixo principal do fator tem a ver com recursos humanos, pode-se dizer que o bom produtor tem capacidade para delinear as características pessoais e profissionais do empregado que ele necessita. Sabe, então, reconhecer dentre os possíveis candidatos aquele que sintetiza as aptidões necessárias ao desempenho das atividades requeridas.

Pelo resultado obtido pela afirmativa 06 (o bom produtor rural é aquele que conhece bem as pessoas que trabalham em sua propriedade), que é parte do fator 3, um bom produtor rural caracteriza-se pela busca de informações que Ihe possibilite tomar a atitude mais vantajosa em termos de contratação de pessoal. Sabe utilizar sua rede de contatos (amigos, parentes, conhecidos, sindicatos, cooperativas) de forma estratégica, para inteirar-se a respeito da idoneidade ou honestidade de possíveis candidatos, seu comportamento pessoal (defeitos e virtudes, vícios) e profissional, sobre sua família, necessidades e exigências. Assim, esta atitude permite ao produtor delinear o perfil da mão-de-obra disponível e verificar se esta atende às suas necessidades.

O conhecimento a respeito das capacidades e limitações dos recursos humanos é fundamental para um bom produtor rural conduzir as atividades rotineiras, uma vez que lhe permite organizar estes recursos de acordo com a exigência de cada tarefa. Além da organização dos recursos humanos, físicos e financeiros de maneira adequada, o bom produtor também tem capacidade de comunicar-se com os subordinados. De acordo com a afirmativa (03) os agricultores sabem que os resultados obtidos também dependem da 
transmissão de ordens e informações aos empregados de forma clara. Assim, todos os envolvidos com determinada atividade sabem o que devem fazer e quais os objetivos e metas envolvidas. Desta forma, um produtor de sucesso é aquele que se faz entender, que sabe o nível de detalhamento das informações ou ordens a serem transmitidas aos empregados, de modo que estes desempenhem suas atividades de forma correta. Sabe que se falar demais, pode confundir o empregado ou repassar informações desnecessárias, confidenciais ou sigilosas; se falar menos que o necessário, pode comprometer o entendimento e a tarefa desempenhada pelo empregado. A comunicação com os subordinados possibilita também ao produtor rural a troca de informações sobre o que está acontecendo na propriedade, inteirar-se sobre os assuntos comunitários e a reavaliação constante do planejamento sem que haja sobreposição de ordens.

As respostas obtidas na afirmativa (02) possibilita afirmar que esta habilidade na comunicação serve tanto para gestão de pessoal como para aprimorar as rotinas comerciais. A troca de informações com as pessoas de sua convivência social e profissional, possibilita o conhecimento dos negócios que estão sendo realizados, os preços e prazos praticados, a confiabilidade de determinados agentes e a identificação de alternativas comerciais para compra e venda. $O$ bom produtor sabe incorporar estas informações ao seu arcabouço de negociação.

O quarto fator, denominado planejamento pessoal, relaciona-se com as atividades de planejamento operacional dos recursos humanos (POR) e planejamento estratégico das finanças (PEF), contribuindo com 5,2\% da variância total observada. O bom produtor rural desempenha cotidianamente um duplo papel, como gestor da produção agropecuária (atributos profissionais) e auxiliar na provisão de recursos financeiros para o lar (atributos pessoais). 
Assim, o quarto fator contempla a capacidade do produtor planejar suas atividades, de modo que seja possível compatibilizar estas duas funções.

As respostas às afirmativas (16) e (17) permite dizer que trabalhando como gestor da produção agropecuária, o produtor de sucesso tem capacidade de planejar as operações na propriedade rural de forma seqüencial, organizando os recursos financeiros, físicos e humanos para que os objetivos produtivos sejam alcançados. Desta forma, o produtor delimita uma estratégia de ação em termos profissionais, ao centralizar tantas responsabilidades estratégicas e operacionais quanto julgue capaz de desempenhar. Ao mesmo tempo, o produtor de sucesso tem condições de avaliar qual o melhor destino para os recursos financeiros obtidos com a atividade agrícola; se para reinvestimento na propriedade, aquisição de ativos físicos, novos negócios ou para finalidades pessoais ou familiares. Assim, o bom produtor tem capacidade e habilidade para determinar qual a profundidade da influência da família na condução das atividades administrativas, sem que esta comprometa a finalidade produtiva. Isto porque a provisão de conforto para os familiares e educação para os filhos pode drenar recursos que seriam aplicados na atividade agrícola.

O fator 5 é responsável por $4,5 \%$ da variância total observada entre as variáveis e relaciona-se positivamente com as atividades de organização operacional dos recursos humanos (OOR) e planejamento estratégico dos recursos humanos (PER), sendo denominado de gerenciamento de pessoal. As afirmações 18 e 14 que compõem o fator 5 permitem inferir sobre a característica do produtor bem sucedido em estar presente constantemente na empresa agrícola e poder, de alguma forma, transmitir aos empregados e familiares suas experiências pessoais. Desta forma, o fator gerenciamento de pessoal vincula-se à capacidade do bom produtor rural em dispor de recursos humanos habilitados de modo a possibilitar a execução de tarefas da maneira 
mais eficiente possível. O produtor de sucesso sabe, então, reconhecer as habilidades e limitações de seus familiares, empregados e demais envolvidos no processo produtivo. Tem condições, portanto, de atuar de forma pontual para monitorar as atividades mais críticas e suprir os pontos fracos, mesmo que para tanto seja necessária a presença constante na propriedade.

O fator 5 também contempla outras características do bom produtor rural. Ao transmitir o próprio conhecimento e experiências acumuladas aos familiares, demonstra a relação pessoal de satisfação e orgulho com a atividade agrícola. Buscando constantemente o contato com as atividades rotineiras desenvolvidas na propriedade é possível visualizar o zelo e a vocação para o trato com a agropecuária.

O fator 6 , organização da produção, responde por $4,4 \%$ da variância total e relaciona-se com a atividade administrativa de organização estratégica da produção (OEP). Este fator indica associação com a capacidade do bom produtor não só em reconhecer a produção que poderá ser alcançada tendo em vista os recursos que lhes são disponíveis, como também de alavancar seus recursos por meio de parcerias. Desta maneira tem condições de estimar o resultado final que poderá ser alcançado com os recursos próprios, conhecer suas limitações e os pontos positivos e negativos de incorporar recursos de terceiros ao processo produtivo: financiamento de máquinas e equipamentos, parcerias, associações e condomínios de exploração agropecuária, associação a uma cooperativa ou sindicato patronal, estabelecimento de sociedades de capital/ trabalho, troca de serviços ou integração vertical com agroindústrias.

Deriva da afirmativa 5 o fato do produtor rural necessitar conhecer quais os benefícios que uma organização conjunta pode trazer, em termos de evitar capacidade ociosa dos recursos, novas oportunidades de negócios, redução de custos, compartilhamento de riscos, ganhos de escala, acesso a tecnologias 
mais avançadas e aumento no poder de barganha. Deve saber que existem dificuldades em operacionalizar estas alternativas, uma vez que há necessidade de confiança entre os envolvidos, de compartilhamento de interesses e de conduta profissionais.

O fator organização da produção (fator 6) contempla a habilidade do produtor trabalhar em grupo e crescer utilizando recursos de terceiros. A relação de confiança que se estabelece com os demais envolvidos sinaliza o reconhecimento social dos valores pessoais (pois ninguém quer trabalhar com indivíduos desonestos ou incompetentes). Além disto, o contato cotidiano com conhecidos ou parceiros contribui para a ampliação do conhecimento prático sobre a atividade agrícola.

O fator 7 responde por 3,9\% do total da variância e relaciona-se às atividades de controle operacional da comercialização (COC) e planejamento operacional da produção (POP). Assim, é chamado de fator aproveitamento de oportunidades. A partir das afirmações 20 e 26 pode-se dizer que este fator vincula-se à capacidade de um produtor de sucesso determinar e reavaliar a seqüência de atividades necessárias para a realização da produção, incorporando novas informações cotidianas ao planejamento anterior. Assim, este fator relaciona-se ao discernimento do produtor rural em estabelecer as operações rotineiras a serem desempenhadas na propriedade de acordo com a conjuntura apresentada. Tal fato possibilita a transformação de oportunidades em negócios lucrativos.

O fator 7 relaciona-se também com a capacidade de avaliar as novas informações e ponderá-las frente ao planejamento estratégico, ou de longo prazo, tendo em vista as necessidades técnicas de rotação de culturas, os custos de aprendizagem ou de alteração da estrutura produtiva às novas alternativas. Este caráter ponderador também se manifesta nas operações 
comerciais. O bom produtor sabe dimensionar corretamente a quantidade dos insumos, máquinas, equipamentos e benfeitorias que viabilizem a produção, procurando adquiri-las no momento certo: quando são necessárias ou quando as condições comerciais são boas.

Por fim, extraído em último lugar, o fator 8 , denominado experiência comercial responde por 3,5\% da variância total observada e relaciona-se com a atividade organização estratégica da comercialização (OEC). Este fator trata do conhecimento do bom produtor rural a respeito dos agentes comerciais, decorrente da experiência pessoal acumulada e dos resultados obtidos com estratégias adotadas anteriormente. Desta forma, um produtor de sucesso tem capacidade para delimitar qual a melhor estratégia de compra ou venda, tendo em vista os canais de comercialização disponíveis, a organização dos agentes comerciais, a confiança dos credores, vendedores e compradores e dos demais riscos envolvidos.

Desta forma, o fator 8, experiência comercial, concentra características pessoais de um bom produtor rural: capacidade e habilidade de negociação, conhecimento formal sobre aspectos legais envolvidos com as transações comerciais ou conhecimento informal sobre os agentes comerciais envolvidos. Também é implícito que o bom produtor rural desperta a confiança dos agentes comerciais.

\subsection{Análise de regressão}

Para quantificar o efeito dos grupos de variáveis síntese (fatores) na explicação das diferentes notas atribuídas à performance dos empresários rurais pelos próprios agricultores, por seus pares e pelos profissionais que thes prestam assistência técnica, foram ajustadas algumas regressões lineares múltiplas. 
Na primeira regressão, a variável dependente foi considerada a nota que os produtores rurais se atribuíram, ou seja, a auto-avaliação. Como variáveis independentes foram incluídos os oito fatores identificados na sessão anterior (4.3.2) e também as cinco variáveis genéricas, que também foram incluídas no questionário, mas que não dizem respeito às atividades administrativas. Quatro notas corresponderam às seguintes questões: (1) satisfação pessoal com a atividade agrícola - denominada "satisfação"; (2) situação atual da agricultura "situação"; (3) preocupação pessoal com a preservação do meio ambiente "ambiente"; e (4) preocupação com a qualidade da própria produção "qualidade". Foi ainda permitido a inclusão, como variável independente, da nota (numa escala de 0 a 3 ) correspondente ao tipo de controle financeiro realizado pelo produtor rural ${ }^{31}$ - variável denominada "controle".

As regressões foram ajustadas seguindo o método stepwise, que permite a entrada seqüencial de variáveis significativas de acordo com critérios preestabelecidos. No presente caso, o critério para entrada de novas variáveis foi o valor 0,1 como limite máximo de significância dos valores obtidos no teste $t$ de Student.

As Tabelas 20 e 21 mostram os resultados obtidos com a regressão da variável "nota da auto-avaliação" como função dos oito fatores e das cinco variáveis adicionais. Pode-se notar que cinco variáveis mostraram a significância requerida: satisfação, qualidade, fator 4 , fator 3 e fator 7 . Todas as variáveis, exceto o fator 4 , apresentaram sinais de acordo com o esperado (positivo). O sinal negativo obtido pelo fator 4 (planejamento pessoal) pode indicar uma relação perversa entre este e a variável dependente. Uma possível

${ }^{31}$ nota 3 = participação do produtor no programa de gerenciamento promovido pela Cotrijal; nota 2 = produtor realiza anotações detalhadas dos custos incorridos com a atividade rural; nota 1 = produtor realiza anotações sintéticas de seus custos, concentrando-se nos principais 
explicação pode ser encontrada nas afirmativas correspondentes às atividades administrativas incluídas neste fator, denominado planejamento pessoal. Uma delas diz respeito ao planejamento operacional de recursos humanos (POR), "o bom produtor rural é aquele que sempre consegue tirar férias e viajar pelo menos uma vez por ano" e a outra ao planejamento estratégico de finanças (PEF), "o bom produtor rural tem como objetivo do empreendimento promover um bom padrão de vida para a família". Desta forma, parece que a influência de questões de cunho pessoal na condução das atividades administrativas (como o fato de tirar férias e promover um bom padrão de vida à família) está prejudicando a performance da empresa, na visão dos próprios produtores rurais.

Tabela 20. Coeficientes da regressão linear simples - variável dependente: auto-avaliação dos entrevistados.

\begin{tabular}{lccc}
\hline \multicolumn{1}{c}{ Variável } & $\begin{array}{c}\text { Coeficiente de } \\
\text { Regressão }\end{array}$ & Beta & Teste t \\
\hline Constante & 3,537794 & & 5,126 \\
& $(0,690170)^{1}$ & & $(0,0000)^{2}$ \\
Satisfação & 0,215576 & 0,344509 & 4,592 \\
& $(0,046945)$ & & $(0,0000)$ \\
Qualidade & 0,289072 & 0,294962 & 3,991 \\
& $(0,072424)$ & & $(0,0001)$ \\
Fator 4 & $-0,185876$ & $-0,175855$ & $-2,381$ \\
& $(0,078082)$ & & $(0,0187)$ \\
Fator 3 & 0,149478 & 0,141420 & 1,934 \\
& $(0,077273)$ & & $(0,0552)$ \\
Fator 7 & 0,134711 & 0,127448 & 1,755 \\
& $(0,076770)$ & & $(0,0816)$ \\
\hline
\end{tabular}

Fonte: resultados da pesquisa.

${ }^{1}$ valor do desvio padrão do coeficiente.

${ }^{2}$ nível de significância do teste t.

valores e nota 0 = produtor não realiza nenhum tipo de controle formal de custos (ou "sabe tudo de cabeça"). 
Tabela 21. Coeficientes da regressão linear simples e teste $F-$ variável dependente: auto-avaliação dos entrevistados.

\begin{tabular}{lr}
\hline Coeficiente/ Teste & Valor \\
\hline $\mathrm{R}$ Múltiplo & 0,54143 \\
$\mathrm{R}^{2}$ & 0,29315 \\
$\mathrm{R}^{2}$ ajustado & 0,26677 \\
Erro padrão & 0,90508 \\
Teste F & 11,11457 \\
Nível de significância de F & 0,0000 \\
\hline
\end{tabular}

Fonte: resultados da pesquisa.

O valor do coeficiente de determinação múltiplo ajustado $\left(R^{2}\right.$ ajustado) é de 0,27 , indicando que $27 \%$ das variações nas notas auto-atribuídas pelos produtores rurais ao seu desempenho como empresário rural, são explicadas pelas cinco variáveis que se mostraram significativas: satisfação, qualidade, fator 4 (planejamento pessoal), fator 3 (comunicação e informação) e fator 7 (aproveitamento de oportunidades). Embora não muito alto, o valor do $\mathrm{R}^{2}$ ajustado foi altamente significativo conforme mostrado pelo valor do teste $\mathrm{F}$.

Considerando como variável dependente a nota atribuída ao desempenho administrativo dos entrevistados por outros agricultores (seus pares), o ajuste da regressão múltipla resulta nos valores mostrados nas Tabelas 22 e 23. Nelas pode-se notar que as variáveis explicativas (considerando-se significância estatística requerida) foram somente duas: "controle" e "fator 1", denominado financeiro. Os sinais de ambos os coeficientes estão de acordo com o esperado (positivo). Este resultado está mostrando que os produtores em geral tem em alta conta aqueles empresários rurais que fazem ou tem capacidade para realizar o controle (contabilidade) de seus gastos e receitas, além de terem melhor desempenho na área financeira. Isto porque o fator 1 foi fortemente associado aos níveis estratégico e operacional das finanças da empresa. 
Tabela 22. Coeficientes da regressão linear simples - variável dependente: avaliação dos entrevistados pelos seus pares.

\begin{tabular}{lccc}
\hline \multicolumn{1}{c}{ Variável } & $\begin{array}{c}\text { Coeficiente de } \\
\text { Regressão }\end{array}$ & Beta & Teste t \\
& 6,554808 & & 37,737 \\
Constante & $(0,173697)^{1}$ & & $(0,0000)^{2}$ \\
& 0,318815 & 0,335070 & 4,141 \\
Controle & $(0,076998)$ & & $(0,0001)$ \\
& 0,136724 & 0,135210 & 1,671 \\
Fator 1 & $(0,081830)$ & & $(0,0970)$ \\
& & & \\
\hline
\end{tabular}

Fonte: resultados da pesquisa.

${ }^{1}$ valor do desvio padrão do coeficiente.

${ }^{2}$ nível de significância do teste $\mathrm{t}$.

Tabela 23. Coeficientes da regressão linear simples e teste $F$ - variável dependente: avaliação dos entrevistados pelos seus pares.

\begin{tabular}{lr}
\hline Coeficientes/ Teste & Valor \\
\hline $\mathrm{R}$ Múltiplo & 0,38949 \\
$\mathrm{R}^{2}$ & 0,15170 \\
$\mathrm{R}^{2}$ ajustado & 0,13932 \\
Erro padrão & 0,93812 \\
Teste F & 12,24972 \\
Nível de significância de F & 0,0000 \\
\hline
\end{tabular}

Fonte: resultados da pesquisa.

O valor do coeficiente $R^{2}$ ajustado foi 0,14 , indicando que $14 \%$ das variações nas notas atribuídas pelos produtores rurais ao desempenho administrativo de seus pares são explicadas pelo modelo. Novamente, o valor do teste $\mathrm{F}$ está mostrando a alta significância da regressão.

As Tabelas 24 e 25 mostram os resultados da regressão da variável "nota atribuídas pelos profissionais da assistência técnica à gestão empresarial dos agricultores" como função dos oito fatores e das cinco variáveis adicionais. Pode-se notar que somente três variáveis mostraram a significância requerida: "controle" e "fator 1"(financeiro), que apresentaram sinais de acordo com o 
esperado (positivo), além da variável "qualidade", que apresentou sinal negativo. Esta variável pode indicar uma relação inversa com relação à nota atribuída à variável dependente. Uma possível explicação pode ser encontrada no fato dos principais produtos agropecuários serem considerados commodities que, por definição, têm qualidade semelhante. É difícil imaginar um técnico levando em consideração o fato do milho, da soja, da carne ou mesmo do leite (tipo C) de um agricultor ser de qualidade melhor do que do produto médio da região. Neste caso, parece que eles estão atribuindo uma nota menor aos agricultores que "se preocupam mais" com a qualidade de sua commodity, ao invés de preocuparem-se com os respectivos índices quantitativos de produção e, principalmente, de produtividade.

Tabela 24. Coeficientes da regressão linear simples - variável dependente: avaliação dos entrevistados pelos técnicos.

\begin{tabular}{lccc}
\hline \multicolumn{1}{c}{ Variável } & $\begin{array}{c}\text { Coeficiente de } \\
\text { Regressão }\end{array}$ & Beta & Teste t \\
& 8,546541 & & \\
\hline Constante & $(0,734906)^{1}$ & & 11,629 \\
& 0,273691 & 0,259224 & $(0,0000)^{2}$ \\
Controle & $(0,084183)$ & & 3,251 \\
& 0,286816 & 0,255614 & $(0,0014)$ \\
Fator 1 & $(0,090132)$ & & 3,182 \\
& $-0,189356$ & $-0,182007$ & $(0,0018)$ \\
Qualidade & $(0,081292)$ & & $-2,329$ \\
& & & $(0,0213)$ \\
\hline
\end{tabular}

Fonte: resultados da pesquisa.

${ }^{1}$ Valor do desvio padrão do coeficiente.

${ }^{2}$ Nível de significância do teste $\mathrm{T}$.

O valor do coeficiente $R^{2}$ ajustado foi 0,16 , indicando que $16 \%$ das variações nas notas atribuídas pelos profissionais da assistência técnica à performance dos agricultores são explicadas pelo modelo. Novamente, o valor do teste $\mathrm{F}$ está mostrando a alta significância desta regressão. 
Tabela 25. Coeficientes da regressão linear simples e teste $F$ - variável dependente: avaliação dos entrevistados pelos técnicos.

\begin{tabular}{lr}
\hline Coeficiente/ Teste & Valor \\
\hline $\mathrm{R}$ Múltiplo & 0,42720 \\
$\mathrm{R}^{2}$ & 0,18250 \\
$\mathrm{R}^{2}$ ajustado & 0,16446 \\
Erro padrão & 1,02566 \\
Teste F & 10,12005 \\
Nível de significância de F & 0,0000 \\
\hline
\end{tabular}

Fonte: resultados da pesquisa.

Outras regressões foram rodadas onde as variáveis independentes foram as originais (notas atribuídas às 32 atividades administrativas), ao invés dos oito fatores, além das cinco variáveis genéricas. O número de variáveis independentes considerado foi muito grande (32 mais 5 variáveis) e os resultados não mostraram melhora sensível quando comparados aos três modelos discutidos. Os resultados dessas últimas regressões estão apresentados no Apêndice 4. 


\section{CONCLUSÕES}

O objetivo geral do trabalho foi a identificação dos fatores que caracterizam um produtor rural de sucesso, com ênfase em sua capacidade administrativa. $O$ trabalho deveria reconhecer $o$ fato de os agricultores (empresários rurais) terem, também, uma dimensão pessoal e familiar que interfere diretamente nas suas atitudes gerenciais, além da procura pelo lucro. O procedimento adotado na pesquisa começou, portanto, com a definição de quais os itens ou características que os produtores e profissionais da assistência técnica consideram importantes na classificação de um produtor como "de mais ou menos sucesso". Este procedimento correspondeu a entrevistas coletivas através da realização de três grupos focais com agricultores e técnicos da Cooperativa Tritícola Mista Alto Jacuí Ltda. - Cotrijal.

As análises dos grupos focais permitiram identificar as variáveis que tanto os produtores quanto os técnicos consideravam importantes na classificação dos produtores rurais. Entre as características de um bom produtor rural foram apontadas: (1) a competência, dada pelo domínio do conhecimento sobre as tecnologias e processos administrativos, pela habilidade de conduzir as atividades de produção e comercialização e por ter atitudes consideradas desejáveis pelo grupo social dos cooperados; (2) a constante procura por informações técnicas e econômicas a respeito dos aspectos produtivos, comerciais, financeiros e de recursos humanos; (3) a participação em eventos ou cursos que ampliem sua qualificação; (4) a realização de 
parceria, associações ou condomínios de produção; (5) a diversificação da produção como estratégia para diminuir riscos; (6) a adoção de novas idéias, tecnologias ou sistemas de produção; (7) a organização da produção e da propriedade em geral; (8) a existência de sistemas de controle financeiro dos gastos e receitas; (9) o planejamento da produção e das atividades da empresa; (10) a liberdade e autonomia decisória, que Ihes permite tirar férias anuais, realizar passeios com a família e a liberdade de fixar seus próprios horários; (11) o envolvimento direto da família com a empresa rural; (12) a promoção de um bom padrão de vida para a família, inclusive oferecendo oportunidades de educação formal aos filhos; (13) o envolvimento com os assuntos comunitários; e, finalmente, (14) ter vocação para a atividade, servir de exemplo para outros empresários e preservar o meio ambiente.

As características do produtor rural bem sucedido, mencionadas nas sessões de grupos focais foram sintetizadas e agrupadas em uma matriz $8 \times 4$, com base na matriz de atividades administrativas, discutida pela teoria da administração. Esta contém entradas correspondentes às quatro funções administrativas (planejamento, organização, direção e controle) em dois níveis empresariais (operacional e estratégico), aplicadas às quatro áreas de atuação na empresa (produção, finanças, comercialização e recursos humanos). Assim, procurou-se identificar dentre as características de um bom produtor rural mencionadas nas sessões focais, aquelas que relacionavam-se às atividades administrativas. Estas características foram transformadas em 32 afirmativas que fizeram parte do questionário aplicado junto aos agropecuristas associados à Cotrijal. A cada afirmação, foi solicitada a atribuição de nota (escala entre zero e dez), de acordo com a maior ou menor concordância do entrevistado com relação à importância da atividade administrativa em questão. Os produtores entrevistados também atribuíram notas (também numa escala entre 0 e 10) ao próprio desempenho, enquanto empresário rural e também a outros 
empresários conhecidos. Posteriormente, foi solicitado aos profissionais da assistência técnica da Cotrijal a atribuição de notas à capacidade administrativa dos produtores rurais entrevistados.

Além de abranger as 32 afirmativas (referentes às atividades administrativas), o questionário aplicado junto a uma amostra de 140 produtores rurais associados à Cotrijal também solicitou a atribuição de notas à satisfação do entrevistado com a atividade agropecuária, com a situação da agropecuária atualmente, com a preocupação pessoal com a preservação do meio ambiente e com a qualidade dos produtos ofertados. O volume de dados primários coletados permitiu a quantificação em termos estatísticos das características atribuídas ao bom produtor rural. Com o grande número de variáveis que foram apontadas como desejáveis nos produtores rurais de sucesso, foi necessário utilizar um procedimento estatístico adequado para manusear o correspondente volume de dados envolvidos. Para tanto foi utilizada a análise fatorial como instrumento de redução do número de variáveis. Ela permitiu agregar as variáveis em oito fatores identificados como: (1) financeiro; (2) planejamento comercial; (3) comunicação e informação; (4) planejamento pessoal; (5) gerenciamento de pessoal; (6) organização da produção; (7) aproveitamento de oportunidades; e (8) experiência comercial. Os oito fatores identificados explicaram $62,3 \%$ da variância total da amostra.

Para quantificar o efeito dos grupos de variáveis (fatores) identificados e de algumas variáveis genéricas que extrapolavam o quadro da matriz de atividades administrativas nas classificações dos produtores rurais (feitas por eles próprios, por seus pares e pelos profissionais da assistência técnica) foram ajustados modelos de regressão linear múltiplos. Embora os coeficientes de explicação das regressões tenham sido, em geral, baixos (27, 14 e 16\%, respectivamente para as notas dos próprios agricultores, dos pares e dos profissionais da assistência técnica) as regressões mostraram-se altamente 
significativas. Os fatores 1 (financeiro), 3 (comunicação e informação), 4 (planejamento pessoal) e 7 (aproveitamento de oportunidades) foram, juntamente com as variáveis genéricas "satisfação" (pessoal com a atividade agropecuária), "qualidade"(da produção ofertada) e "controle" (físico e financeiro de gastos e receitas), significantes (até $10 \%$ no teste t) na explicação das notas atribuídas aos empresários rurais.

Embora os participantes dos grupos focais tenham enfatizado que outras necessidades além da procura por lucro e, portanto, de uma eficiente gestão financeira, são igualmente importantes na definição de um bom empresário rural, o fator 1 (financeiro) respondeu pela maior parte da variância da amostra $(25,3 \%)$ na análise fatorial. Além disso, foi significativo (com o sinal correto) na explicação das notas dadas tanto pelos técnicos quanto pelos outros agricultores (pares).

Os agricultores da Cotrijal formam um grupo diferenciado quando se considera os agricultores do Brasil em geral; praticamente não convivem com analfabetismo, tem boa educação formal até o nível médio e, acima de tudo, tem uma forte herança cultural com ênfase na ética de trabalho e maior estoque de capital social. A variação nas notas atribuídas aos empresários rurais foi menor do que se esperaria em uma amostra correspondente a um universo maior de agricultores brasileiros. Recomenda-se, portanto, a replicação do presente trabalho em outras áreas. O encadeamento dado pelo grupo focal para levantamento das variáveis explicativas consideradas importantes, seguida de aplicação de questionário para permitir análise estatística multivariada e ajustamento de regressões para mensurar os efeitos das variáveis explicativas mostrou-se um procedimento adequado. 


\section{REFERÊNCIAS BIBLIOGRÁFICAS}

ACCARINI, J.H. Economia rural e desenvolvimento: reflexões sobre o caso brasileiro. Petrópolis: Vozes, 1987. 224p.

ANDRADE, J.G. de. Introdução à administração rural. Lavras: UFLA/ FAEPE, 1996. 106p.

ANDRADE, T.A. Métodos estatísticos e econométricos aplicados à análise regional. In: HADDAD, P.R. (Org.) Economia regional: teoria e métodos de análise. Fortaleza: BNB/ETENE, 1989. cap.9, p.497-507.

ARISTIMUNHA, J.L.; VELA, H.A.G. Uma breve leitura das estruturas organizacionais dos agricultores familiares no planalto médio rio-grandense. Perspectiva Econômica, v.33, n.104, p.5-16, 1998.

BADER, G.E.; ROSSI, C.A. Focus groups: a step-by step guide. San Diego: The Bader Group, 1999. 39p.

BASSO, N. Práticas administrativas em uma associação de pequenos agricultores no Rio Grande do Sul. Lavras, 1993. 69p. Dissertação (Mestrado) - Escola Superior de Agricultura, Universidade Federal de Lavras. 
BIALOSKORSKI NETO, S.; BALIEIRO, C.F. Capital social e cooperativas na agricultura do estado de São Paulo: um ensaio analítico. Ribeirão Preto: FEA/USP, 2000. 8p. (Texto para Discussão. Série Economia, 12)

BRUMER, A. Qual a vocação produtiva da agricultura familiar? Globalização, produção familiar e trabalho na agricultura. In: TEDESCO, J.C. (Org.) Agricultura familiar: realidades e perspectivas. Passo Fundo: EDIUPF, 1999. cap.6, p.219-249.

CANZIANI, J.R.F. Assessoria a produtores rurais no Brasil. Piracicaba, 2001. 224p. Tese (Doutorado) - Escola Superior de Agricultura "Luiz de Queiroz", Universidade de São Paulo.

CARLINI-COTRIM, B. Potencialidades da técnica qualitativa grupo focal em investigações sobre abuso de substâncias. Revista Saúde Pública, v.30, n.3, p.285-293, 1996.

CHIAVENATO, I. Introdução à teoria geral da administração. São Paulo: Makron Books, 1997. cap.7, p.227-284: Teoria neoclássica da administração.

COOPERATIVA TRITÍCOLA MISTA ALTO JACUÍ LTDA. - COTRIJAL. Núcleo de grãos. 'hinttp://wwww.cotrijali.com.bri. (10 janeiro 2002)

DALMAZO, N.L.; ALBERTONI, L.A. A necessidade de um enfoque de administração rural na pesquisa e extensão rural. In: SEMANA DE ATUALIZAÇÃO EM ADMINISTRAÇÃO RURAL, Lages, 1991. Anais. Florianópolis: SAA/EPAGRI/CTA do Planalto Serrano Catarinense, 1992. p.7-21. 
GUERRA, G. Manual de administracion de empresas agropecuárias. San José: Instituto Interamericano de Cooperación para la Agricultura, 1992. $508 p$.

HAIR, J.F.J.; ANDERSON, R.E.; TATHAN, R.L.; BLACK, W.C. Multivariate data analysis. New Jersey: Prentice Hall, 1998. cap.3, p.87-138: Factor analysis.

HOFFMANN, R. Componentes principais e análise fatorial. Piracicaba: ESALQ/USP, 1999. 40p. (Série Didática, 90)

JORNAL DA COTRIJAL. Não-Me-Toque: Imperial Artes Gráficas Ltda., jan.out.2001.

LAUSCHNER, R. Agribusiness, cooperativa e produtor rural. São Leopoldo: Editora Unisinos, 1993. 293p.

MALHOTRA, N.K. Pesquisa em marketing. Porto Alegre: Bookman, 2001. cap.19, p.503- 523: Análise fatorial.

MAXIMIANO, A.C. Introdução à administração. 4.ed. São Paulo: Atlas, 1995. 476p.

MAXIMIANO, A.C. Administração de projetos: como transformar idéias em resultados. São Paulo: Atlas, 1997. cap.11, p.145-153: Autoridade e competência. 
MEIRA, J.L. Sucesso econômico e perfil estrategista empreendedor de produtores rurais: o caso Nilo Coelho. Lavras, 1996. 76p. Dissertação (Mestrado) - Escola Superior de Agricultura, Universidade Federal de Lavras.

MENDONÇA, M.C.A. Estilos gerenciais e suas relações com os desempenhos técnicos e econômicos na pecuária leiteira. Lavras, 1996. 69p. Dissertação (Mestrado) - Escola Superior de Agricultura, Universidade Federal de Lavras.

MIRANDA, D. de. Associativismo rural, agroindústria e intervenção: estudo de caso de uma associação de produtores familiares. Lavras, 1998. 202p. Dissertação (Mestrado) - Escola Superior de Agricultura, Universidade Federal de Lavras.

NEUBERN, F.J.; PERES, F.C.; CESTARI, P.M.J. Process of strategic adjustment of rural enterprises in the region of Garça, SP - Brazil. In: INTERNATIONAL FARM ADMINISTRATION CONGRESS, 12., Durban, 1999. Anais. Durban: s.ed., 1999. p.77-89.

NIX, J.S. Farm management: the state of the arts (or science). Journal of Agricultural Economics, v.30, n.3, p.277-291, Sep. 1979.

NORONHA, J.F.; PERES, F.C. Rumos futuros da administração rural. In: SEMANA DE ATUALIZAÇÃO EM ADMINISTRAÇÃO RURAL, Lages, 1991. Anais. Florianópolis: SAA/EPAGRI/CTA do Planalto Serrano Catarinense, 1992. p.251-260. 
NORTON, G.W.; ALWANG, J. Introduction to economics of agricultural development. New York: McGraw-Hill, 1993. cap.9, p.149-166: Comparative agricultural systems and the role of women.

PORTER, M.E. Vantagem competitiva: criando e sustentando um desempenho superior. Rio de Janeiro: Campus, 1992. 512p.

SALLES, S.B. de. Efeitos de um sistema de registros agropecuários na eficiência gerencial do empresariado rural: o caso do sistema Fidene no Rio Grande do Sul. Porto Alegre, 1981. 98p. Dissertação (Mestrado) Faculdade de Ciências Econômicas, Universidade Federal do Rio Grande do Sul.

SAMPAIO, C.H. Orientação para o mercado em cooperativas agrícolas no Rio Grande do Sul. Perspectiva Econômica, v.33, n.104, p.17-33, 1998.

SEBILLOTE, M. (Dir.) Los procesos de toma de decisiones de los agricultores: contribuiciones recentes. Paris: Academie d'Agriculture, 1988. $34 p$.

SHARMA, S. Applied multivariate techniques. New York: John Wiley, 1996. cap.4, p.58-89: Principal components analysis; cap.5, p.90-123: Factor analysis.

SILVA NETO, B.; LIMA, A.J.P. de; BASSO, D. Teoria dos sistemas agrários: uma nova abordagem do desenvolvimento da agricultura. Extensão Rural, v.4, n.4, p.6-19, 1997. 
VILLAVICENCIO, J.C. Criterios administrativos para el manejo de la explotación agropecuaria. Caracas: Fundación Editorial de la Universidad "Rómulo Gallegos", 1992. 127p.

WESTHUIZEN, C. van der; VILJOEN, M.F. The relationship between the performance of farmers and their biography and management practices. In: INTERNATIONAL FARM ADMINISTRATION CONGRESS, 12., Durban, 1999. Anais. Durban: s.ed., 1999. p.869-881.

WESTPHAL, M.F.; BÓGUS, C.M.; FARIA, M. de M. Grupos focais: experiências precursoras em programas educativos em saúde no Brasil. Boletín de la Oficina Sanitaria Panamericana, v.120, n.6, p.472-482, 1996. 
APÊNDICE 1

Questionário 


\section{QUESTIONÁRIO SOBRE ADMINISTRAÇÃO RURAL}

- Pedimos sua colaboração para responder esse questionário. Ele faz parte de um projeto de dissertação de mestrado desenvolvido por um engenheiro agrônomo e pós-graduando da Escola Superior de Agricultura "Luiz de Queiroz" da Universidade de São Paulo. Através dele, pretende-se conhecer melhor a opinião e a percepção dos produtores rurais sobre alguns temas relacionados à administração da empresa agropecuária no Brasil.

- Nenhuma informação individual será divulgada.

Nome do produtor rural:

Indique apenas a sua exploração agropecuária mais importante em termos de receita financeira:

Indique a sua idade:

Indique quantos anos você freqüentou a escola:

Qual a nota de 0 (zero) à 10 (dez) que você se daria como produtor rural? Zero seria a nota para um péssimo produtor rural, cinco para o médio e 10 para um excelente produtor rural.

Nota:

Dê uma nota de 0 (zero) à 10 (dez) para:

a) Sua satisfação na atividade agrícola. NOTA:

b) Para a situação atual da agricultura. NOTA:

c) Para sua preocupação com a preservação do meio ambiente. NOTA:

d) Para sua preocupação com a qualidade de sua produção (grãos, leite, carne). NOTA: 
Quanto ao controle financeiro, o senhor como empresário rural: (marque somente uma alternativa)

( ) Participa do programa de gerenciamento da COTRIJAL.

( ) Não faz nenhum tipo de anotação para o controle de gastos (sabe tudo de cabeça).

( ) Faz anotações dos principais (maiores) custos da propriedade.

( ) Faz anotações detalhadas dos custos de sua propriedade rural.

$1^{\text {a) }}$ Responda se você concorda ou não com as afirmações abaixo, atribuindo notas de 0 (zero) à dez (10):

- Nota 0 (zero) significa que você discorda integralmente com a afirmação

- Notas de 1 (um) a 4 (quatro) significa que você discorda parcialmente com a afirmação

- Nota 5 (cinco) significa que você é indiferente a afirmação

- Notas de 6 (seis) a 9 (nove) significa que você concorda parcialmente com a afirmação

- Nota 10 (dez) significa que você concorda integralmente com a afirmação

Discordo Integralmente

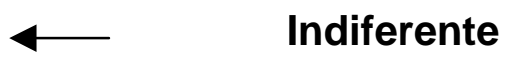

Indiferente

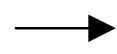

0 1

2

3

4

5
$7 \quad 8$

$7 \quad 8$

\section{Concordo Integralmente}

$9 \quad 10$

1) O bom produtor rural faz planejamento ou orçamento de qual a melhor época de comprar adubo, sementes, defensivos agrícolas.

2) O bom produtor rural é aquele que acompanha, cotidianamente, os preços de mercado, tanto dos produtos quanto dos insumos.

3) O bom produtor rural faz com que todos os empregados fiquem sabendo o que foi planejado. Assim, todos sabem o que têm que fazer. 4) O bom produtor rural faz diversificação da produção para se proteger de frustrações de safras, de preços baixos e diminuir as variações de sua renda. 
5) O bom produtor rural sempre adota a estratégia de fazer parceria, associação ou condomínios de produção agropecuária para diminuir os custos de produção e os riscos da atividade agrícola.

6) O bom produtor rural é aquele que conhece bem as pessoas que trabalham em sua propriedade.

7) O bom produtor rural sempre vende sua produção de acordo com a necessidade de caixa (dinheiro) para pagar os compromissos financeiros.

8) O bom produtor rural consegue produzir com produtividade mais alta e custos mais baixos que seus vizinhos.

9) O bom produtor rural é aquele que sabe, efetivamente, se suas atividades estão dando lucro ou prejuízo.

10) O bom produtor rural sempre mantém a lavoura com um bom aspecto visual, livre de pragas e doenças e mantém instalações, máquinas e equipamentos limpos e bem conservados.

11) O bom produtor rural sempre possui um sistema de controle, mesmo que simplificado, do tipo entradas e saídas de dinheiro do caixa.

12) O bom produtor rural é aquele que deixa para a cooperativa toda a estratégia de comercialização de sua produção.

13) O bom produtor rural sempre é o responsável pelas compras e vendas na propriedade. Só transações de pequenos valores podem ser feitas pelos empregados da propriedade.

14) O bom produtor rural sempre delega atividades aos filhos com o objetivo de fazer seu sucessor e dar continuidade a propriedade rural no futuro.

15) O bom produtor rural sabe que sem a cooperativa ele acabará na mão de intermediários inescrupulosos ou de grandes empresas na hora de vender sua produção.

16) O bom produtor rural é aquele que sempre consegue tirar férias e viajar pelo menos uma vez por ano.

17) $O$ bom produtor rural tem como objetivo principal do empreendimento rural promover um bom padrão de vida para família (como, por exemplo, dar boa educação para os filhos, ter um bom plano de saúde e dispor de conforto dentro de casa).

18) O bom produtor rural deve estar sempre presente na propriedade rural, pois assim ele pode acompanhar e participar de perto do desenvolvimento dos trabalhos.

19) O bom produtor rural sempre passa as ordens de serviços aos empregados de forma clara e direta.

20) O bom produtor rural sempre procura adquirir insumos a preços menores e compra somente o mínimo necessário.

21) O bom produtor rural é aquele que vende sua produção apenas quando precisa de recursos financeiros. 
22) O bom produtor rural sempre adota rapidamente novas técnicas de produção (é inovador) e investe em novas máquinas e equipamentos.

23) O bom produtor rural é aquele que sabe distinguir a boa da má informação quanto a preços e qualidade dos insumos disponíveis no mercado.

24) O bom produtor rural sempre participa de encontros técnicos, cursos e feiras agropecuárias e estimula seus empregados e familiares a participarem de cursos de capacitação rural.

25) O bom produtor rural é aquele que conhece ou procura informações sobre os preços históricos dos produtos (séries históricas de preços).

26) O bom produtor rural define o que vai produzir anualmente com base nos preços de mercado.

27) O bom produtor rural é aquele que é copiado pelos outros, que serve de exemplo na forma de condução do seu empreendimento.

28) O bom produtor rural sempre tem um controle separado dos gastos da família e dos gastos com as atividades da propriedade.

29) O bom produtor rural sempre zela pela sua imagem visual.

30) O bom produtor rural é aquele que faz anotações dos seus gastos e obrigações financeiras de longo prazo.

31) O bom produtor rural sempre controla seus gastos e sabe analisar os dados levantados (anotados) de modo que torne possível saber qual foi o lucro obtido em cada atividade.

32) O bom produtor rural sempre toma atitude diante das dificuldades financeiras e não fica esperando passivamente do governo uma solução para os seus problemas.

$\left.2^{2}\right)$ Dentre os produtores rurais que você conhece (vizinhos e conhecidos), dê uma nota entre 0 (zero) e 10 (dez) para a capacidade de administrar uma propriedade rural.

\begin{tabular}{|l|l|}
\hline Nome do Produtor & Nota (0 a 10) \\
\hline & \\
\hline & \\
\hline & \\
\hline & \\
\hline & \\
\hline
\end{tabular}




\section{APÊNDICE 2}

\section{Freqüência absoluta de notas}


Tabela 26. Freqüência absoluta de notas atribuídas pelos entrevistados à satisfação com a atividade agrícola, situação atual da agricultura, preocupação com a preservação do meio ambiente e com a qualidade da própria produção e às atividades administrativas.

\begin{tabular}{|c|c|c|c|c|c|c|c|c|c|c|c|c|c|}
\hline $\begin{array}{l}\text { NOTAS } \\
\text { ATIVIDADES }\end{array}$ & 0 & 1 & 2 & 3 & 4 & 5 & 6 & 7 & 8 & 9 & 10 & Média & Mediana \\
\hline Satisfacão & 0 & 0 & 0 & 0 & 5 & 11 & 8 & 15 & 40 & 24 & 37 & 8.100 & 8 \\
\hline Situação & 1 & 0 & 2 & 7 & 9 & 36 & 36 & 29 & 12 & 4 & 4 & 5.946 & 6 \\
\hline Ambiente & 0 & 0 & 0 & 0 & 0 & 10 & 10 & 16 & 39 & 24 & 41 & 8.289 & 8 \\
\hline Qualidade & 0 & 0 & 0 & 0 & 0 & 1 & 3 & 12 & 41 & 43 & 40 & 8.729 & 9 \\
\hline CEC & 0 & 0 & 1 & 2 & 3 & 7 & 10 & 12 & 24 & 27 & 54 & 8.389 & 9 \\
\hline CEF & 0 & 0 & 0 & 1 & 0 & 4 & 10 & 10 & 15 & 19 & 81 & 8.957 & 10 \\
\hline CEP & 5 & 0 & 2 & 1 & 1 & 14 & 4 & 12 & 30 & 23 & 48 & 7.975 & 9 \\
\hline CER & 0 & 0 & 0 & 0 & 2 & 1 & 2 & 8 & 17 & 19 & 91 & 9.271 & 10 \\
\hline $\mathrm{COC}$ & 2 & 0 & 2 & 0 & 1 & 3 & 6 & 7 & 32 & 29 & 58 & 8.611 & 9 \\
\hline COF & 0 & 0 & 0 & 1 & 0 & 13 & 6 & 15 & 26 & 19 & 60 & 8.489 & 9 \\
\hline COP & 0 & 1 & 0 & 0 & 1 & 2 & 4 & 6 & 20 & 19 & 87 & 9.161 & 10 \\
\hline COR & 1 & 1 & 1 & 0 & 2 & 19 & 9 & 9 & 28 & 18 & 52 & 8.064 & 8,5 \\
\hline DEC & 2 & 0 & 1 & 1 & 1 & 11 & 5 & 13 & 21 & 22 & 63 & 8.436 & 9 \\
\hline DEF & 0 & 0 & 0 & 0 & 0 & 7 & 1 & 3 & 19 & 25 & 85 & 9.211 & 10 \\
\hline DEP & 0 & 0 & 1 & 1 & 5 & 16 & 11 & 11 & 32 & 23 & 40 & 7.936 & 8 \\
\hline DER & 0 & 0 & 0 & 0 & 3 & 9 & 4 & 10 & 24 & 31 & 59 & 8.657 & 9 \\
\hline DOC & 0 & 0 & 0 & 0 & 1 & 2 & 5 & 9 & 35 & 24 & 64 & 8.879 & 9 \\
\hline DOF & 5 & 0 & 1 & 4 & 5 & 9 & 7 & 17 & 30 & 26 & 36 & 7.671 & 8 \\
\hline DOP & 0 & 0 & 0 & 0 & 0 & 14 & 6 & 16 & 41 & 27 & 36 & 8.211 & 8 \\
\hline DOR & 0 & 0 & 0 & 0 & 0 & 5 & 1 & 8 & 23 & 22 & 81 & 9.136 & 10 \\
\hline OEC & 3 & 0 & 1 & 2 & 4 & 14 & 2 & 9 & 26 & 30 & 49 & 8.121 & 9 \\
\hline OEF & 0 & 0 & 0 & 0 & 2 & 3 & 4 & 13 & 21 & 29 & 68 & 8.911 & 9 \\
\hline OEP & 1 & 0 & 3 & 6 & 3 & 24 & 5 & 16 & 26 & 13 & 43 & 7.521 & 8 \\
\hline OER & 0 & 0 & 0 & 1 & 1 & 1 & 2 & 10 & 19 & 22 & 84 & 9.171 & 10 \\
\hline OOC & 0 & 0 & 0 & 0 & 1 & 12 & 3 & 15 & 30 & 25 & 54 & 8.514 & 9 \\
\hline OOF & 0 & 0 & 0 & 0 & 1 & 5 & 4 & 12 & 28 & 26 & 64 & 8.821 & 9 \\
\hline OOP & 0 & 0 & 0 & 1 & 1 & 1 & 3 & 11 & 21 & 21 & 81 & 9.100 & 10 \\
\hline OOR & 0 & 0 & 0 & 0 & 0 & 6 & 0 & 5 & 20 & 20 & 89 & 9.250 & 10 \\
\hline PEC & 13 & 2 & 3 & 3 & 7 & 10 & 9 & 17 & 30 & 15 & 31 & 6.807 & 8 \\
\hline PEF & 0 & 1 & 0 & 0 & 0 & 3 & 3 & 12 & 19 & 26 & 76 & 9.029 & 10 \\
\hline PEP & 0 & 0 & 1 & 2 & 2 & 2 & 8 & 13 & 22 & 29 & 61 & 8.657 & 9 \\
\hline PER & 0 & 0 & 0 & 0 & 2 & 2 & 1 & 9 & 26 & 20 & 80 & 9.107 & 10 \\
\hline POC & 6 & 1 & 4 & 3 & 4 & 15 & 4 & 20 & 32 & 14 & 37 & 7.321 & 8 \\
\hline POF & 0 & 0 & 1 & 0 & 1 & 5 & 8 & 9 & 33 & 23 & 60 & 8.664 & 9 \\
\hline POP & 5 & 1 & 1 & 5 & 3 & 11 & 18 & 23 & 39 & 16 & 18 & 7.071 & 8 \\
\hline POR & 14 & 1 & 1 & 5 & 5 & 19 & 15 & 12 & 17 & 15 & 36 & 6.700 & 7 \\
\hline
\end{tabular}

Fonte: resultados da pesquisa. 
APÊNDICE 3

Resultados de análise fatorial 
Tabela 27. Cargas fatoriais dos 8 fatores analisados e comunalidades das 32 atividades administrativas.

\begin{tabular}{lrrrrr}
\hline & Fator 1 & Fator 2 & Fator 3 & Fator 4 & Fator 5 \\
\hline CEC & 0,49617 & 0,06121 & 0,50847 & 0,03252 & $-0,14336$ \\
CEF & $\mathbf{0 , 7 3 5 6 0}$ & 0,02583 & $-0,01642$ & 0,04322 & 0,08285 \\
CEP & 0,17359 & 0,46609 & 0,44365 & 0,12361 & 0,10353 \\
CER & $-0,01404$ & 0,02621 & $\mathbf{0 , 7 6 9 4 4}$ & 0,01114 & 0,14507 \\
COC & 0,07393 & 0,21308 & $-0,06198$ & 0,22411 & 0,26002 \\
COF & $\mathbf{0 , 7 3 9 1 1}$ & $-0,15047$ & $-0,01711$ & 0,07539 & 0,13440 \\
COP & 0,59696 & $-0,16688$ & 0,22060 & 0,06628 & 0,16679 \\
COR & 0,14121 & 0,18676 & $-0,07576$ & 0,49794 & 0,09389 \\
DEC & 0,01660 & 0,38979 & 0,09411 & 0,05442 & 0,43546 \\
DEF & $\mathbf{0 , 7 1 4 5 2}$ & 0,07429 & 0,05376 & $-0,05983$ & 0,18777 \\
DEP & 0,32142 & 0,41008 & 0,22074 & 0,24347 & 0,01639 \\
DER & 0,16973 & 0,09592 & $\mathbf{0 , 6 3 1 8 6}$ & 0,14991 & 0,08903 \\
DOC & 0,25809 & 0,27169 & $\mathbf{0 , 6 5 0 5 2}$ & 0,18165 & 0,08105 \\
DOF & $-0,00915$ & $\mathbf{0 , 7 7 7 4 2}$ & 0,10330 & 0,03245 & 0,06385 \\
DOP & 0,12224 & $-0,09693$ & 0,17955 & 0,18847 & $-0,04138$ \\
DOR & 0,49541 & 0,18684 & 0,22316 & 0,07856 & 0,04401 \\
OEC & 0,23109 & 0,11106 & 0,20474 & 0,13259 & 0,18219 \\
OEF & $\mathbf{0 , 7 3 3 5 9}$ & $-0,00807$ & 0,05807 & 0,22582 & 0,12790 \\
OEP & 0,25767 & 0,08599 & 0,10267 & $-0,01511$ & 0,11640 \\
OER & 0,58101 & 0,01635 & 0,20834 & 0,15040 & $-0,06555$ \\
OOC & 0,45780 & 0,02732 & 0,20174 & 0,53532 & 0,03428 \\
OOF & $\mathbf{0 , 6 2 3 6 6}$ & 0,08881 & 0,08869 & 0,12134 & 0,00640 \\
OOP & 0,45532 & 0,15195 & 0,38962 & 0,01133 & 0,33665 \\
OOR & 0,24999 & 0,22162 & 0,06700 & 0,13077 & $\mathbf{0 , 6 9 5 8 8}$ \\
PEC & $-0,05698$ & $\mathbf{0 , 7 9 5 1 8}$ & 0,08872 & $-0,02777$ & 0,09321 \\
PEF & 0,13374 & $-0,07088$ & 0,07894 & $\mathbf{0 , 7 5 4 4 0}$ & 0,24526 \\
PEP & 0,45173 & 0,30216 & 0,30204 & 0,05323 & $-0,04033$ \\
PER & 0,14610 & 0,10356 & 0,15782 & 0,07793 & $\mathbf{0 , 8 4 6 4 8}$ \\
POC & $-0,08856$ & $\mathbf{0 , 7 2 3 4 1}$ & $-0,00428$ & 0,04285 & 0,15953 \\
POF & 0,56348 & $-0,04543$ & 0,20382 & 0,34892 & 0,03111 \\
POP & 0,05656 & 0,42275 & 0,04812 & $-0,14471$ & 0,05417 \\
POR & 0,10570 & $\mathbf{0 , 1 1 5 4 0}$ & $\mathbf{0}, 13420$ & $\mathbf{0 , 6 3 5 8 9}$ & $-0,08089$
\end{tabular}


Tabela 27. Cargas fatoriais dos 8 fatores analisados e comunalidades das 32 atividades administrativas.

\begin{tabular}{lrrrr}
\hline & Fator 6 & Fator 7 & Fator 8 & Comunalidade \\
\hline CEC & 0,07404 & 0,32924 & 0,04185 & 0,64571 \\
CEF & 0,27212 & $-0,10739$ & 0,17765 & 0,66792 \\
CEP & 0,23815 & $-0,09216$ & 0,07335 & 0,54079 \\
CER & 0,09496 & 0,04491 & 0,14094 & 0,64498 \\
COC & 0,07556 & $\mathbf{0 , 6 3 9 6 0}$ & 0,17468 & 0,61785 \\
COF & 0,06782 & 0,06605 & 0,09348 & 0,61067 \\
COP & $-0,10220$ & 0,31332 & $-0,00249$ & 0,57371 \\
COR & 0,34893 & 0,04517 & 0,30441 & 0,53378 \\
DEC & 0,40459 & $-0,10740$ & 0,23858 & 0,58581 \\
DEF & 0,13526 & $-0,24944$ & 0,03228 & 0,63934 \\
DEP & $-0,21268$ & 0,04433 & 0,26313 & 0,49618 \\
DER & 0,24681 & $-0,06204$ & 0,22120 & 0,58136 \\
DOC & $-0,12475$ & 0,01678 & $-0,38999$ & 0,77111 \\
DOF & 0,00461 & 0,19887 & $-0,06305$ & 0,66381 \\
DOP & 0,52264 & 0,46216 & 0,10574 & 0,59173 \\
DOR & $-0,01884$ & 0,04938 & 0,57500 & 0,67167 \\
OEC & 0,05864 & $-0,01018$ & $\mathbf{0 , 6 5 8 3 1}$ & 0,59535 \\
OEF & 0,09035 & 0,05116 & 0,04896 & 0,62212 \\
OEP & $\mathbf{0 , 7 0 0 9 3}$ & 0,05940 & $-0,01598$ & 0,59307 \\
OER & 0,31003 & 0,07657 & 0,17310 & 0,54011 \\
OOC & $-0,04274$ & 0,23516 & 0,06149 & 0,59968 \\
OOF & 0,07642 & 0,16553 & 0,03387 & 0,45386 \\
OOP & 0,10198 & 0,19094 & 0,13591 & 0,56100 \\
OOR & 0,02018 & 0,21612 & 0,06615 & 0,66893 \\
PEC & 0,07256 & $-0,05624$ & 0,17382 & 0,69153 \\
PEF & $-0,15027$ & $-0,04839$ & $-0,06591$ & 0,68752 \\
PEP & 0,44975 & $-0,23409$ & $-0,26055$ & 0,71601 \\
PER & 0,07220 & 0,03821 & 0,05198 & 0,78896 \\
POC & 0,06929 & 0,22933 & 0,04238 & 0,61766 \\
POF & $-0,09453$ & $-0,11872$ & $-0,40974$ & 0,67475 \\
POP & 0,01971 & $\mathbf{0}, 66208$ & $-0,21065$ & 0,69119 \\
POR & 0,34549 & 0,09960 & 0,10414 & 0,59352 \\
\hline Fon & & & &
\end{tabular}

Fonte: resultados da pesquisa. 
Tabela 28. Autovalor (eigenvalue), percentual de variância e percentual de variância acumulada dos 8 fatores analisados.

\begin{tabular}{lrrrrrrrr}
\hline & Fator 1 & Fator 2 & Fator 3 & Fator 4 & Fator 5 & Fator 6 & Fator 7 & Fator 8 \\
\hline Auto- & & & & & & & & \\
valor & 8,10458 & 3,18287 & 1,75279 & 1,66719 & 1,45429 & 1,40470 & 1,23976 & 1,12548 \\
\% Var. & 25,3 & 9,9 & 5,5 & 5,2 & 4,5 & 4,4 & 3,9 & 3,5 \\
\%Acum. & 25,3 & 35,3 & 40,8 & 46,0 & 50,5 & 54,9 & 58,8 & 62,3 \\
\hline
\end{tabular}

Fonte: resultados da pesquisa. 


\section{APÊNDICE 4}

Resultados de análise de regressão 
Tabela 29. Coeficientes da regressão linear simples - variável dependente: auto-avaliação dos entrevistados.

\begin{tabular}{lccc}
\hline \multicolumn{1}{c}{ Variável } & $\begin{array}{c}\text { Coeficiente de } \\
\text { Regressão }\end{array}$ & Beta & Teste t \\
& 4,624837 & & 5,440 \\
Constante & $(0,850097)^{1}$ & & $(0,0000)^{2}$ \\
& 0,211296 & 0,337669 & 4,694 \\
Satisfação & $(0,045012)$ & & $(0,0000)$ \\
& 0,325105 & 0,331729 & 4,648 \\
Qualidade & $(0,069951)$ & & $(0,0000)$ \\
& $-0,222722$ & $-0,300071$ & $-4,197$ \\
PEF & $(0,053069)$ & & $(0,0000)$ \\
& 0,176078 & 0,222782 & 2,995 \\
OOP & $(0,058782)$ & & $(0,0033)$ \\
& $-0,106992$ & $-0,154958$ & $-2,100$ \\
CEF & $(0,050946)$ & & $(0,0376)$ \\
& & &
\end{tabular}

Fonte: resultados da pesquisa.

${ }^{1}$ valor do desvio padrão do coeficiente.

${ }^{2}$ nível de significância do teste t.

Tabela 30. Coeficientes da regressão linear simples e teste $F$ - variável dependente: auto-avaliação dos entrevistados

\begin{tabular}{lr}
\hline Coeficiente/ Teste & Valor \\
\hline $\mathrm{R}$ Múltiplo & 0,59713 \\
$\mathrm{R}^{2}$ & 0,35656 \\
$\mathrm{R}^{2}$ ajustado & 0,33255 \\
Erro padrão & 0,86353 \\
Teste F & 14,85122 \\
Nível de significância de F & 0,0000 \\
\hline
\end{tabular}

Fonte: resultados da pesquisa. 
Tabela 31. Coeficientes da regressão linear simples - variável dependente: avaliação dos entrevistados pelos seus pares.

\begin{tabular}{lccc}
\hline \multicolumn{1}{c}{ Variável } & $\begin{array}{c}\text { Coeficiente de } \\
\text { Regressão }\end{array}$ & Beta & Teste t \\
\hline Constante & 6,366201 & & 9,161 \\
& $(0,694951)^{1}$ & & $(0,0000)^{2}$ \\
Controle & 0,376324 & 0,395511 & 5,038 \\
& $(0,074696)$ & & $(0,0000)$ \\
PEF & $-0,116440$ & $-0,163982$ & $-2,063$ \\
& $(0,056440)$ & & $(0,0410)$ \\
OOP & 0,123568 & 0,163423 & 2,058 \\
& $(0,060028)$ & & $(0,0415)$ \\
\hline
\end{tabular}

Fonte: resultados da pesquisa.

${ }_{1}^{1}$ valor do desvio padrão do coeficiente.

${ }^{2}$ nível de significância do teste t.

Tabela 32. Coeficientes da regressão linear simples e teste $F$ - variável dependente: avaliação dos entrevistados pelos seus pares.

\begin{tabular}{lr}
\hline Coeficiente/ Teste & Valor \\
\hline R Múltiplo & 0,42159 \\
$\mathrm{R}^{2}$ & 0,17774 \\
$\mathrm{R}^{2}$ ajustado & 0,15960 \\
Erro padrão & 0,92700 \\
$\mathrm{~F}$ & 9,79938 \\
Nível de significância de F & 0,0000 \\
\hline
\end{tabular}

Fonte: resultados da pesquisa. 
Tabela 33. Coeficientes da regressão linear simples - variável dependente: avaliação dos entrevistados pelos técnicos.

\begin{tabular}{lccc}
\hline \multicolumn{1}{c}{ Variável } & $\begin{array}{c}\text { Coeficiente de } \\
\text { Regressão }\end{array}$ & Beta & Teste t \\
& 6,374315 & & \\
\hline Constante & $(0,843774)^{1}$ & & 7,555 \\
Controle & 0,300099 & 0,284235 & $(0,0000)^{2}$ \\
& $(0,080991)$ & & 3,705 \\
COP & 0,236969 & 0,302211 & $(0,0003)$ \\
& $(0,060578)$ & & 3,912 \\
Qualidade & $-0,195266$ & $-0,187688$ & $(0,0001)$ \\
& $(0,079870)$ & & $-2,445$ \\
& & & $(0,0158)$ \\
\hline
\end{tabular}

Fonte: resultados da pesquisa.

1 valor do desvio padrão do coeficiente.

${ }^{2}$ nível de significância do teste t.

Tabela 34. Coeficientes da regressão linear simples e teste $F$ - variável dependente: avaliação dos entrevistados pelos técnicos.

\begin{tabular}{lr}
\hline Coeficiente/ Teste & Valor \\
\hline $\mathrm{R}$ Múltiplo & 0,45876 \\
$\mathrm{R}^{2}$ & 0,21046 \\
$\mathrm{R}^{2}$ ajustado & 0,19305 \\
Erro padrão & 1,00796 \\
$\mathrm{~F}$ & 12,08423 \\
Nível de significância de F & 0,0000 \\
\hline
\end{tabular}

Fonte: resultados da pesquisa. 